GEOLOGICAL SURVEY CIRCULAR 839

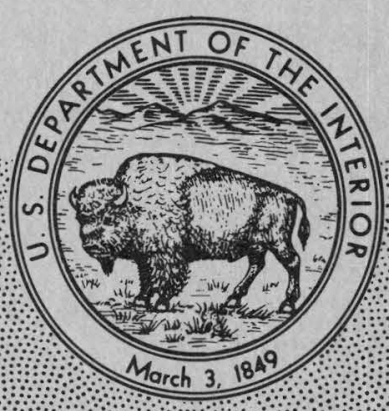

Assessment of Impacts of Proposed Coal-Resource and Related Economic

Development on Water Resources,

Yampa River Basin, Colorado and

Wyoming-A Summary 

Assessment of Impacts of Proposed

Coal-Resource and Related Economic

Development on Water Resources,

Yampa River Basin, Colorado and

Wyoming-A Summary

Compiled and Edited by Timothy Doak Steele and Donald E. Hillier

GEOLOGICAL SURVEY CIRCULAR 839 


\section{United States Department of the Interior}

CECIL D. ANDRUS, Secretary

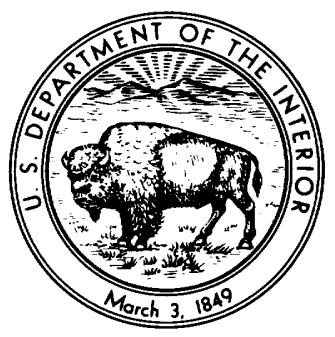

\section{Geological Survey}

H. William Menard, Director 


\section{FOREWORD}

The American public has been concerned with the enhancement and protection of the environment at minimal social costs, particularly with respect to development and use of the Nation's energy resources. Substantial investments made during recent years to protect and improve air and water quality are being evaluated critically for effectiveness and social desirability. A review of existing and pending legislation which establishes acceptable National goals for environmental protection (including air- and water-quality standards and land-use planning) indicates a trend in setting more realistic goals in response to changing policies on economic development and energy consumption.

The Yampa River basin assessment is one of a series of multidisciplinary studies supported by the U.S. Geological Survey. The intent of these studies is to determine the types and forms of hydrologic, geologic, and other information useful to decision-making at Federal, State, and local levels in analyses of policies affecting development and use of natural resources.

Decisions affecting policy of energy-resource development need to consider the environmental, social, and economic impacts of such development. Expanded energy-resource development will lead to increased generation and discharge of residual waste materials to the land, to surface and ground waters, and into the air. Through modification or treatment, some residual wastes having no economic value may be converted to commercial byproducts of economic value. Discharge of residuals generally will have some impact on environmental quality. Any plan to modify or reduce these discharges may affect the basin's water resources, in terms of water withdrawals, water consumption, and assimilative capacity. Planning for the development and management of the natural resources of the Yampa River basin is needed in the context of these uncertainties.

This report summarizes several studies conducted to evaluate the waterresources related consequences of various alternative proposals for energyresource development in the Yampa River basin, primarily in terms of increased mining and conversion of near-surface coal. The intended audience of this report includes those regional and basin planners and managers, involved in areas of expanding energy development, who are concerned with water use and environmental impacts.

PHILIP COHEN Chief Hydrologist 


\section{PREFACE}

“. . . communication to the public and its representatives of knowledge of alternative opportunities for water management and use will result in more rational decisions."

National Academy of Sciences, 1968, p. 81 


\section{CONTENTS}

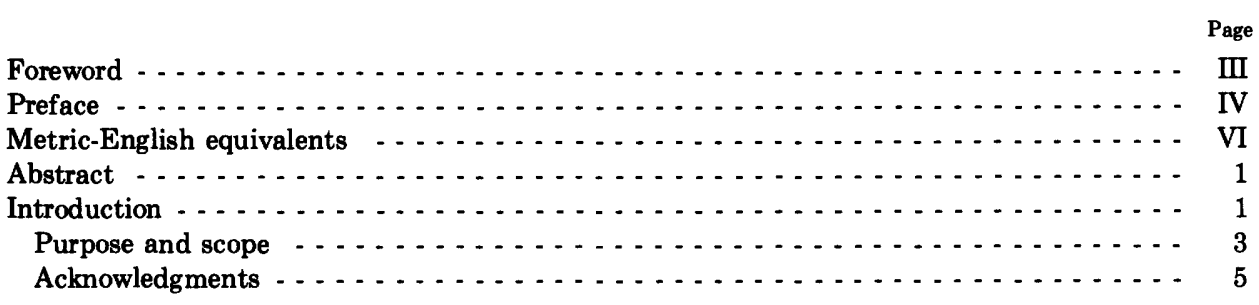

\section{Part I. Study framework}

Regional coal-resource development alternatives and assessment approaches, by T. D. Steele Legal aspects of water-resources development, by W. I. Knudsen, Jr., and J. A. Danielson Technical information in planning and management of regional water resources in areas of coal-development potential, by I. C. James II and P. E. Stark . . . . . . . . . . .

Part II. Assessment techniques

Regional economic analysis for predicting water use and waste residuals, by J. E. Schefter Water-use and residuals implications of coal-conversion and transportation alternatives,

by R. M. Hirsch . . . . . . . . . . . . . . . . . . . . . . . . . 20

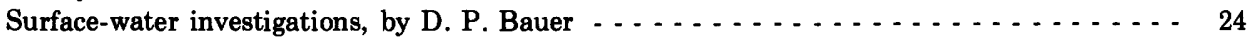

Stream quality, by D. A. Wentz _. . . . . . . . . . . . . . . . . . . . . . . . 31

Regional sediment characteristics, by E. D. Andrews _ . . . . . . . . . . . . . . . 42

Remote-sensing applications, by F. J. Heimes . . . . . . . . . . . . . . . . . . 46

Solute-transport modeling of ground water, by J. W. Warner _ . . . . . . . . . . . 47

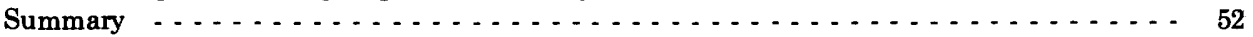

References ...................................... 53

\section{ILLUSTRATIONS}

FIGURe 1. Scenes from the Yampa River basin - -

2. Map of the Yampa River basin, Colorado and Wyoming, showing location of coal- resource development and various study areas ............ 4

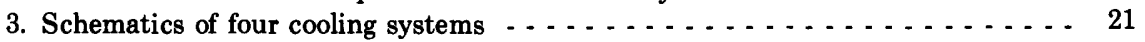

4-7. Graphs showing:

4. Comparison of water use for alternative cooling systems of coal use assuming 12.5 million tons of coal mined per year $\ldots \ldots \ldots \ldots$

5. Projections of total residuals resulting from coal-development alternatives,

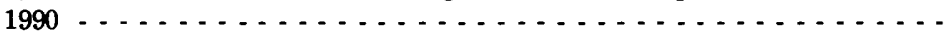

6. Computed concentrations of ammonia nitrogen for existing wastewater-treatment facilities and 7-day low flows with a 10-year recurrence interval in

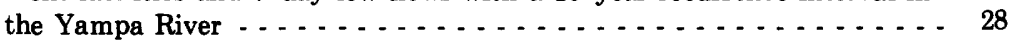

7. Comparison of mean monthly variations in regulated and unregulated streamflow and dissolved-solids concentrations, Yampa River at Deerlodge Park, Colo., 1951-69 water years ... . . . . . . . . . . . . . . . .

8. Map showing location of sites where streamflow was sampled during the basinwide reconnaissance, August-September 1975, and during the quarterly sampling program, December 1975 through August-September 1976 . . . . 
FIGURE 9. Graph showing frequency distributions of total manganese in streamflow,

August-September 1975 through August-September 1976 . . . . . . . . .

10. Graph showing frequency distributions of arsenic in stream-bottom sediments,

August-September 1975 through August-September $1976 \ldots . . . . . . .$. 11-13. Maps showing:

11. Areal distribution of sediment yields extrapolated from station records -

12. Lineament and fault map superimposed on Landsat scene that includes the western part of the Yampa River basin, February 26, 1975 . . . . .

13. Projected increases in dissolved-solids concentrations in ground water resulting from all mines in the Twentymile Park model area . . . . .

\section{TABLES}

TABLE 1. Coal-resource development alternatives, 1975-90 . . . . . . . . . . . . . .

2. Estimates of water-withdrawal coefficients, water-withdrawal multipliers, and total water withdrawal, by sector, for the Colorado part of the Yampa River basin in $1975 \ldots \ldots \ldots \ldots \ldots \ldots . . . \ldots \ldots$

3. Comparison of the impact of four alternative coal-use processes on selected aspects of the environment, Colorado part of the Yampa River basin . . . . . . . .

4. Direct and indirect impacts, of four different coal-use processes, Colorado part of

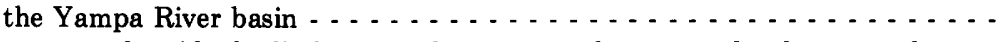

5. Water-use and residuals discharge under seven coal-resource development alterna-

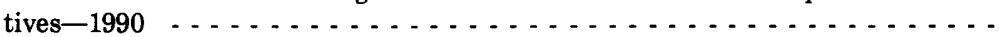

6. Comparison of four cooling technologies assuming mining of 12.5 million tons (11.3 million $t)$ of coal per year . . . . . . . . . . . . . . . . 22

7. Proposed major surface-water impoundments, reservoir-modeling analysis _... 30

8. Seasonal maximum likely ambient concentrations of chemical constituents in streamflow, August-September 1975 through August-September 1976 . . - . - . - -

9. Potential sediment yields from surface-mined areas for three estimated levels of coal

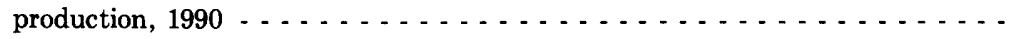

\section{METRIC-ENGLISH EQUIVALENTS}

[The inch-pound units used in this report may be converted to metric units by the following conversion factors]

\begin{tabular}{lcl}
\hline To convert & Multiply by & Toobtain \\
\hline $\begin{array}{l}\text { square foot per second } \\
\left(\mathrm{ft}^{2} / \mathrm{s}\right)\end{array}$ & 0.0929 & $\begin{array}{l}\text { square meter per second } \\
\left(\mathrm{m}^{2} / \mathrm{s}\right)\end{array}$ \\
$\begin{array}{l}\text { cubic foot per second } \\
\left(\mathrm{ft}^{3} / \mathrm{s}\right)\end{array}$ & 0.02832 & $\begin{array}{l}\text { cubic meter per second } \\
\left(\mathrm{m}^{3} / \mathrm{s}\right)\end{array}$ \\
mile $(\mathrm{mi})$ & & kilometer $(\mathrm{km})$ \\
square mile $\left(\mathrm{mi}^{2}\right)$ & 1.609 & square kilometer $\left(\mathrm{km}^{2}\right)$ \\
acre & 2.590 & hectare $(\mathrm{ha})$ \\
acre-foot (acre-ft) & 0.4047 & cubic meter $\left(\mathrm{m}^{3}\right)$ \\
gallon (gal) & 1,233 & liter $(\mathrm{L})$ \\
cubic meter $\left(\mathrm{m}^{3}\right)$ \\
ton (short) & 3.785 & metric ton $(\mathrm{t})$ \\
British thermal unit (Btu) & 0.003785 & joule $(\mathrm{J})$ \\
pound & 0.9072 & kilogram $(\mathrm{kg})$ \\
\end{tabular}




\title{
Assessment of Impacts of Proposed Coal-Resource and Related Economic Development on Water Resources, Yampa River Basin, Colorado and Wyoming-A Summary
}

\author{
Compiled and Edited by Timothy Doak Steele and Donald E. Hillier
}

\section{ABSTRACT}

Expanded mining and use of coal resources in the Rocky Mountain region of the western United States will have substantial impacts on water resources, environmental amenities, and social and economic conditions. The U.S. Geological Survey has completed a 3-year assessment of the Yampa River basin, Colorado and Wyoming, where increased coal-resource development has begun to affect the environment and quality of life. Economic projections of the overall effects of coal-resource development were used to estimate water use and the types and amounts of waste residuals that need to be assimilated into the environment. Based in part upon these projections, several physical-based models and other semiquantitative assessment methods were used to determine possible effects upon the basin's water resources.

Depending on the magnitude of mining and use of coal resources in the basin, an estimated 0.7 to 2.7 million tons $(0.6$ to 2.4 million metric tons) of waste residuals may be discharged annually into the environment by coal-resource development and associated economic activities. If the assumed development of coal resources in the basin occurs, annual consumptive use of water, which was approximately 142,000 acre-feet (175 million cubic meters) during 1975, may almost double by 1990 . In a related analysis of alternative cooling systems for coalconversion facilities, four to five times as much water may be used consumptively in a wet-tower, cooling-pond recycling system as in once-through cooling. An equivalent amount of coal transported by slurry pipeline would require about one-third the water used consumptively by once-through cooling for in-basin conversion.

Current conditions and a variety of possible changes in the water resources of the basin resulting from coal-resource development were assessed. Basin population may increase by as much as threefold between 1975 and 1990 . Volumes of wastes requiring treatment will increase accordingly. Potential problems associated with ammonia-nitrogen concentrations in the Yampa River downstream from Steamboat Springs were evaluated using a waste-load assimilative-capacity model. Changes in sediment loads carried by streams due to increased coal mining and construction of roads and buildings may be apparent only locally; projected increases in sediment loads relative to historic loads from the basin are estimated to be 2 to 7 percent.
Solid-waste residuals generated by coal-conversion processes and disposed of into old mine pits may cause widely dispersed ground-water contamination, based on simulation-modeling results. Projected increases in year-round water use will probably result in the construction of several proposed reservoirs. Current seasonal patterns of streamflow and of dissolvedsolids concentrations in streamflow will be altered appreciably by these reservoirs. Decreases in time-weighted mean-annual dissolved-solids concentrations of as much as 34 percent are anticipated, based upon model simulations of several configurations of proposed reservoirs.

Detailed statistical analyses of water-quality conditions in the Yampa River basin were made. Regionalized maximum waterquality concentrations were estimated for possible comparison with future conditions. Using Landsat imagery and aerial photographs, potential remote-sensing applications were evaluated to monitor land-use changes and to assess both snow cover and turbidity levels in streams. The technical information provided by the several studies of the Yampa River basin assessment should be useful to regional planners and resource managers in evaluating the possible impacts of development on the basin's water resources.

\section{INTRODUCTION}

Water is an important resource contributing to the physical and economic well-being of any region. The amount and quality of "available" water are factors affecting the economic development that may occur. With time, economic development will affect the water resources of a region through withdrawals and consumptive use of water in various economic activities and discharge of waste residuals (that is, byproducts of a process that have no economic value) that eventually may enter the hydrologic system (Kneese and Bower, 1968).

The Yampa River basin in northwestern Colorado and southcentral Wyoming is a region of natural beauty which has remained largely unaffected by the activities of humans (fig. 1A-C). Its 

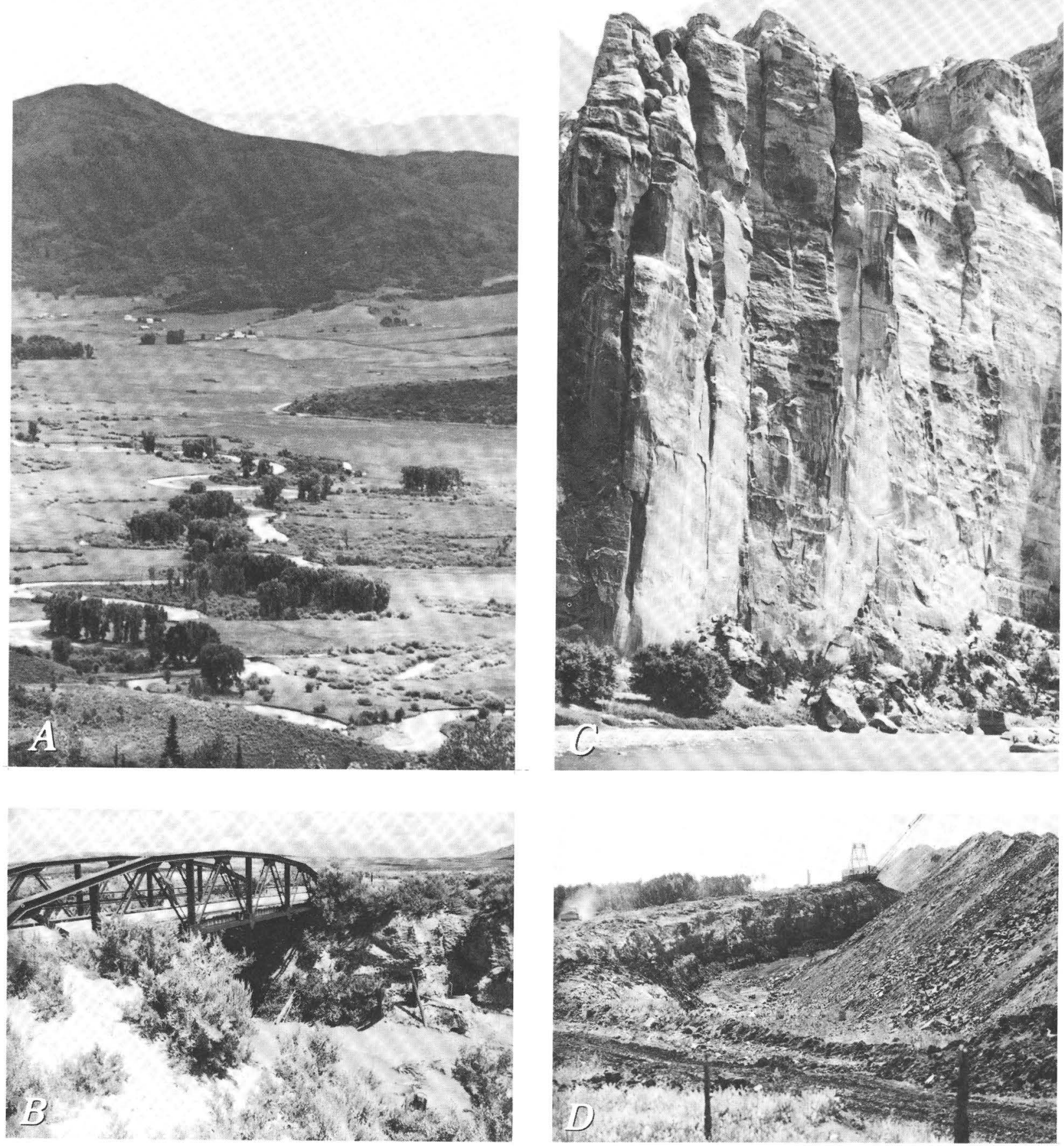

FiguRE 1.(above and facing page)-Scenes from the Yampa River basin: A. Yampa River above Steamboat Springs, Colo. B. Muddy

Creek near Baggs, Wyo. C. Weber Sandstone, Dinosaur National Monument, Colo. D. Dragline at Energy Fuels No. 1. Mine.

E. Hayden Powerplant. F. Runoff from waste spoils, Edna Mine.

scenery and recreational activities attract many campers, skiers, fishermen, and white-water floaters. Economic development in the Yampa River basin traditionally has been dominated by agricultural and recreational use of its water and other natural resources. However, this historical dominance is changing, due to increasing demands being placed upon the region's resources as a result of energy-resource development (fig. 1D-F) (James and Steele, 1977). 

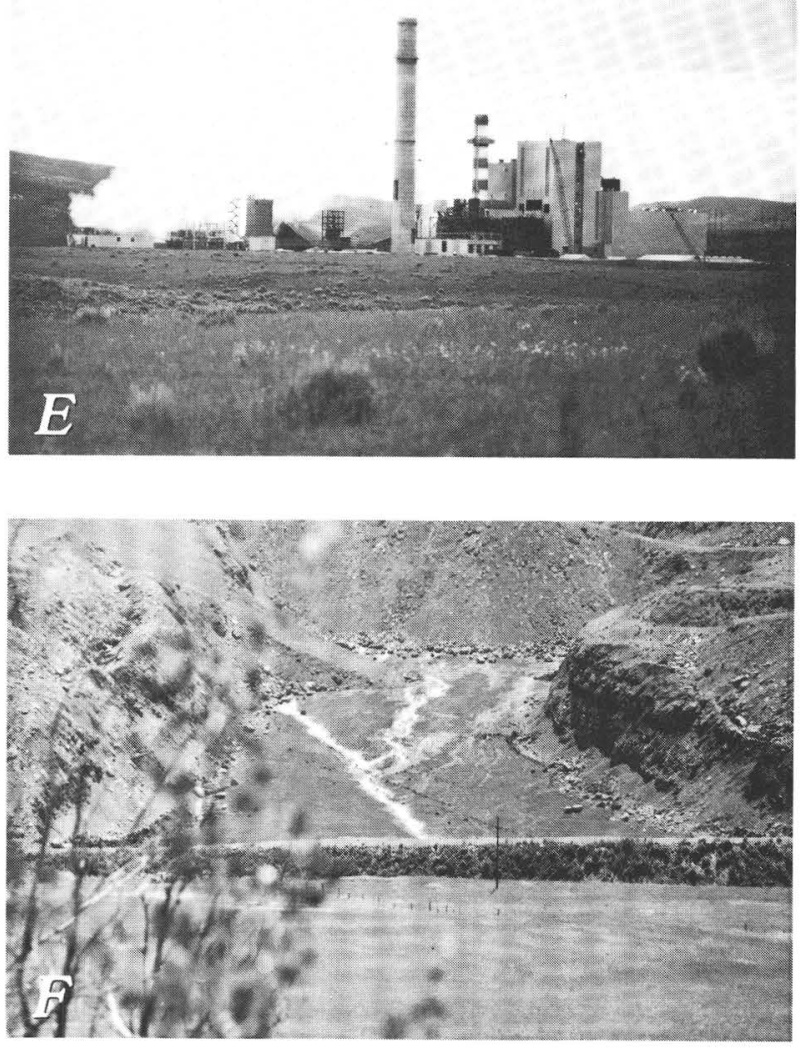

The basin encompasses an area of approximately $8,080 \mathrm{mi}^{2}\left(20,900 \mathrm{~km}^{2}\right)$; about three-fourths of the basin is located in northwestern Colorado and onefourth is located in Wyoming (fig. 2). In Colorado, Moffat and Routt Counties (fig. 2) constitute nearly two-thirds of the total drainage area of the basin, contain about 80 percent of the basin's population, and have the majority of the economic activity. Primarily for these reasons, many of the component studies dealt more with conditions in the Colorado part of the basin. The regional setting of the Yampa River basin is described by Steele, Bauer, Wentz, and Warner (1979).

\section{PURPOSE AND SCOPE}

The Yampa River basin assessment was a multidisciplinary project conducted by the U.S. Geological Survey to demonstrate the application of methods for evaluating existing water resources in a region (Greeson and others, 1977), and to assess potential effects of impending coal-resource and associated economic development on the region's limited water resources. In addition to evaluating hydrologic processes that might be affected by the discharge of gaseous, liquid, and solid residuals to the environment, the assessment included: (1) A summary of the effects that State water laws and Federal compacts may have on the availability and distribution of water resources; (2) a summary of how technical information may be used in regional planning and management of water resources; and (3) regional economic and water-use analyses based on various alternatives of coal-resource and associated economic development.

The basin assessment demonstrated how a variety of assessment methods could be applied interactively. It also provided some general indication of how application of these techniques might be useful to other regions facing similar development and constraints on limited available resources. Detailed data and technical analyses dealing with the region's water resources were designed to fulfill some of the information needs for regional planning and decisionmaking.

In the design and implementation of the basin assessment, various project activities were coordinated with other studies being conducted concurrently in the basin. The two phases of the basin assessment were outlined by Steele, Bauer, Wentz, and Warner (1976a) and by Steele, James, Bauer, and others (1976b). In the first phase, existing environmental conditions in the basin and feasible coal-development alternatives were described (Steele, Bauer, and others, 1979). In the second phase, some potential direct (coal-resource related) and indirect (related to the associated economic development) effects of coal-resource development alternatives on the region's water resources were evaluated. All study results are documented in detail in a series of special-topic reports, which are included in the references at the end of this report.

The principal investigator(s) of each basinassessment study are indicated by authorship of each chapter composing this report. Other personnel affiliated with each study generally are acknowledged by the report(s) cited in each chapter and listed in the references.

The first three chapters of this report discuss the general aspects of the assessment, including the inherent need for technical information in decisionmaking. The remaining seven chapters briefly describe the assessment techniques used and indicate possible applications to water-resources assessments in other regions undergoing energy development. 


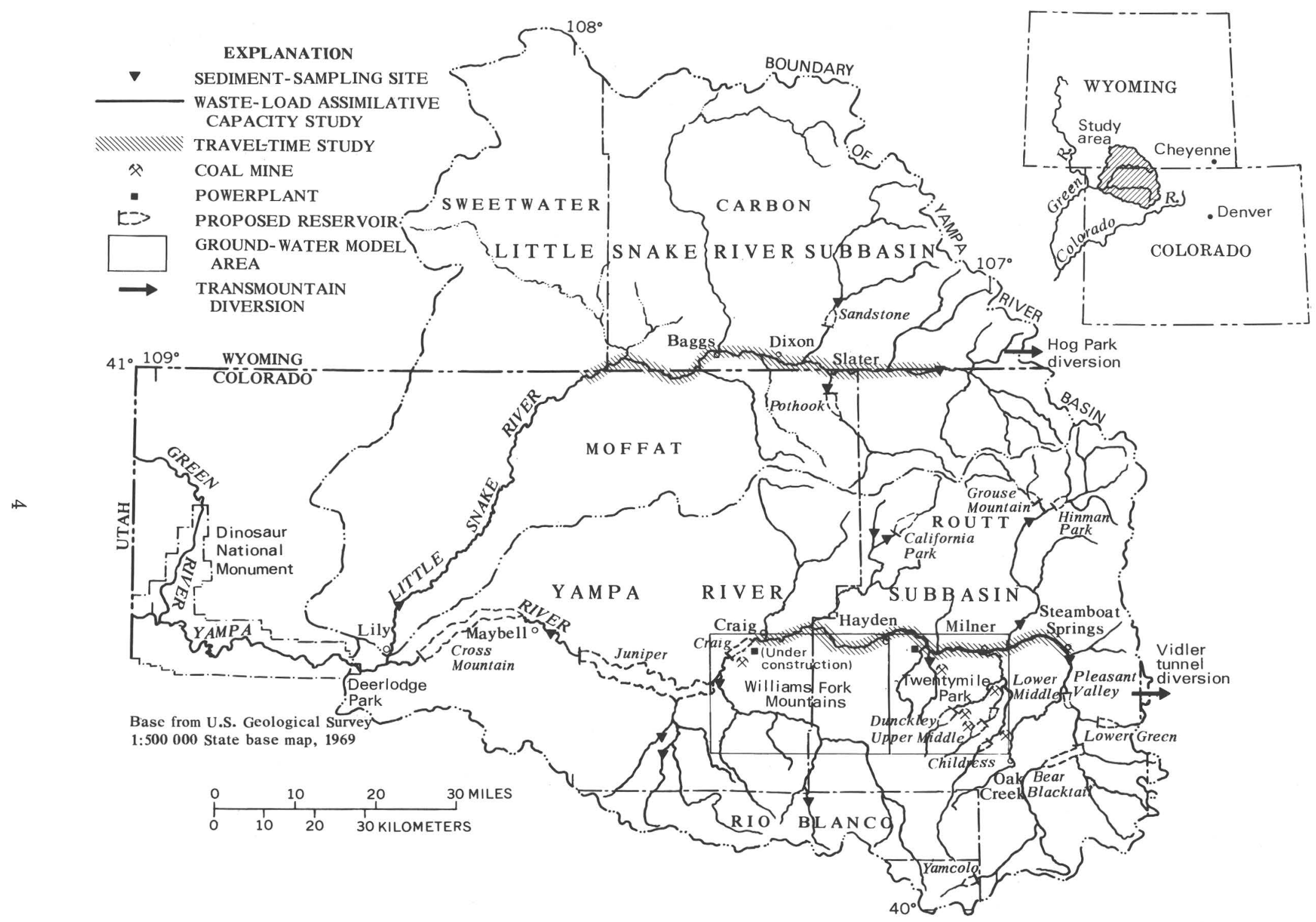

FiguRE 2.-The Yampa River basin, Colorado and Wyoming, showing location of coal-resource development and various study areas. (Modified from Steele, 1978a.) 


\section{ACKNOWLEDGMENTS}

Contractual studies conducted as part of the basin-assessment project included:

1. Regional economic input-output analysis of Routt and Moffat Counties: Bernard Udis, R. C. Hess, T. H. Adams, D. V. Orr, and consulting economists associated with the Bureau of Economic Research, University of Colorado, Boulder, Colo.

2. Water rights and institutional analysis: W. I. Knudsen, Jr., and J. A. Danielson, of the Colorado Department of Natural Resources, Division of Water Resources, Office of the State Engineer, Denver, Colo.

Other individuals contributing to basinassessment studies included: P. E. Stark, Routt
County Department of Environmental Health; R. M. Eddy, U.S. Environmental Protection Agency, Technical Investigations Branch, Surveillance and Analysis Division, Region VIII; and R. D. Anderson, Colorado Department of Health, Water Quality and Control Division.

U.S. Geological Survey personnel assisting in specific studies included: G. K. Moore, remotesensing applications; R. E. Rathbun and D. A. Schultz, instream-reaeration studies; and J. D. Sherman, multireservoir analysis. Additional support to various studies was provided by D. B. Tramberg, Stockton, Calif.; T. L. Washington, Denver, Colo.; P. E. Harrold, Bradley, Ill.; S. M. Hofford, Fort Collins, Colo.; Dan Sinn, Lawrence, Kans.; and numerous personnel of the Colorado and Wyoming District offices of the U.S. Geological Survey.

\section{PART I. STUDY FRAMEWORK}

\section{REGIONAL COAL-RESOURCE DEVELOPMENT ALTERNATIVES AND ASSESSMENT APPROACHES}

\author{
By Timothy Doak STeElE ${ }^{1}$
}

Most coal-resource development in the Yampa River basin-at least through 1990-is expected to occur in areas south of the Yampa River between Steamboat Springs, Colo., and Craig, Colo. (fig. 2), where there are extensive coal deposits that have been or will be leased, largely by the Federal government (U.S. Department of the Interior, 1976a, fig. RI-3, p. RI-7 and 8). Projections of coal production are subject to some uncertainty because of various regulations and Federal policy affecting the rate of leasing and development. Moreover, environmental-control measures currently in force may change. Consequently, regional-r.2source planners have to cope with these and other uncertainties when considering the ramifications of mining, processing, energy conversion, and transportation of coal, especially with respect to waste residuals released to the environment and water use (Steele, James, and others,

${ }^{1}$ Former Project Chief, Yampa River Basin Assessment; Currently with Woodward Clyde Consultants, Denver, Colo. 1976b; Steele, Bauer, and others, 1979). Alternatives for disposal of waste residuals and water use in mining will vary with mining techniques and required land reclamation (Keefer and Hadley, 1976).

Starting with conditions for the base year 1975, seven assumed coal-resource development alternatives, projected at 5-year intervals to 1990 , were developed (Udis and others, 1977; Steele and others, 1979), which are summarized in table 1. These alternatives are based in part on coalproduction projections for the basin described in the Northwest Colorado Coal environmental statement (U.S. Department of the Interior, 1976a). A maximum coal production of 20 million tons (18 million $t$ ) per year was assumed for 1990 in alternatives 1-4; a 50-percent variance in coal production was assumed in alternatives $5-7$. The seven alternatives imply that coal mined in the basin may be used in different ways. That is, all coal mined in the basin between 1975 and 1990 will not be converted to electricity or gas products by plants within the basin, nor will all coal mined be transported in raw form by railroads or possibly a slurry pipeline to markets outside the basin. Rather, a combination of such uses, listed in table 1, probably will occur. 
[From Steele, Bauer, Wentz, and Warner (1979). Development alternatives assume coal use for electric-power generation to average 3,500 tons per year per megawatt of generation capacity. In reality, coal use will be affected by such factors as plant efficiency, plant size, quality of the coal, and environmental controls imposed on residuals. The 1975 base reflects a 430-megawatt capacity at the Hayden Powerplant]

Type of growth and alternative ${ }^{1}$

Coal use, in millions of tons per year

\begin{tabular}{llll}
\hline 1975 & 1980 & 1985 & 1990
\end{tabular}

Slow:

7 Electric powerplants (760 megawatts)--

Rail road exports---------.---

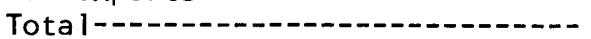

$\begin{array}{ll}1.50\left({ }^{2} 1980\right) & 4.20 \\ 3.10 & \frac{1.80}{6.00}\end{array}$

4.20

4.20

$\frac{3.10}{4.60}$

6.00

3.80

$\frac{5.80}{10.00}$

\section{Moderate:}

1 Electric powerplants (760 megawatts)--

Railroad exports--.--

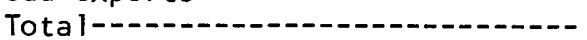

2 Electric powerplants (760 megawatts)--

Coal gasification plants $(250 \mathrm{million}$

$\frac{1.50}{3.10}$

$(21980)$

$1.50\left({ }^{2} 1980\right)$ standard cubic feet each).

Railroad exports----.---.--

Total--.--

3 Electric powerplants (760 megawatts) $(1,200$ megawatts $)$.

Rail road exports----_-

Total-1-_-

4 Electric powerplants (760 megawatts) $(1,200$ megawatts $)$.

Slurry pipeline--.-.

Railroad exports--.-_-

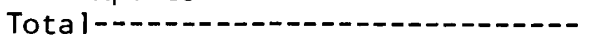

$$
0
$$

$\frac{3.10}{4.60}$

$1.50\left({ }^{2} 1980\right)$

$\frac{3.10}{4.60}$

$1.50\left({ }^{2} 1980\right)$

3.10

$\frac{3.10}{4.60}$

$\begin{array}{r}4.20 \\ 5.80 \\ \hline 10.00\end{array}$

4.20

$0 \quad(21985)$

$\frac{5.80}{10.00}$

4.20

$\frac{5.80}{10.00}$

$4.20\left({ }^{2} 1982\right)$

$\frac{0}{5.80}$
4.20

10.80

$\overline{15.00}$

4.20

15.80

$\frac{15.80}{20.00}$

4.20

4.20

$6.25(21990)$

12.50

3.30

$\frac{3.30}{20.00}$

8.40

11.60

$\overline{20.00}$

8.40

8.40

$\begin{array}{lll}0 & (21989) & 10.00\end{array}$

6.60

$\frac{6.60}{15.00}$

$\frac{1.60}{20.00}$

\section{Rapid:}

5 Electric powerplants (760 megawatts)

$(2,800$ megawatts $)$

$(4,800$ megawatts $)$.

Railroad exports--.-.-.-

Total---_..-

6 Electric powerplants $(760$ megawatts)

$1.50\left({ }^{2} 1980\right)$

4.20

$(21985)$

$14.00\left({ }^{2} 1990\right)$

30.80

$\frac{3.10}{4.60}$

$\frac{7.80}{12.00}$

$\frac{10.00}{24.00}$

0

$(1,200$ megawatts $)$

$(3,200$ megawatts $)$.

Coal gasification plant (250 million 0

$1.50\left({ }^{2} 1980\right)$

$4.20\left({ }^{2} 1985\right)$

24.00

$\overline{30.80}$

standard cubic feet).

Rail road exports- $\quad 3.10$
Total-

$0 \quad\left({ }^{2} 1985\right)$

6.25

6.25

$\frac{3.10}{4.60}$

$\frac{7.80}{12.00}$

$\frac{9.35}{24.00}$

$\frac{4.95}{30.80}$

${ }^{1}$ Sequence code as given in Udis, Adams, Hess, and Orr (1977).

${ }^{2}$ Year in which additional capacity becomes fully operational.

In developing the alternatives, primary consideration was given to meeting the estimated demand by coal-fired power-generation plants, which currently is a major proposed use of coal in the basin. The first two alternatives assumed the coalfired power-generation capacity existing or being constructed in the basin-the Hayden and Craig powerplants (fig. 2). The remaining coal produced 
was then allocated to other uses: transportation out of the basin by railroads or slurry pipeline, and coal gasification. In the third and fourth alternatives, plans for proposed expansions of the Hayden and Craig powerplants, doubling the capacity that is existing or being constructed, were assumed to be completed, with the remaining coal production being used as listed in table 1 . The fifth and sixth alternatives assumed that part or all of the proposed 6,400-megawatt Oak Creek coal-fired power-generation facility might be constructed by 1990 (Oak Creek Power Co., 1976). These alternatives assumed a 1990 coal-production rate of more than 30 million tons ( 27 million $t$ ), which would leave sufficient coal for only one coalgasification plant for alternative 6 , with the remainder being transported out of the basin. A seventh alternative was included to provide a lessthan-projected rate of development (table 1). The rate of future Federal coal leasing, as well as other factors, will affect the extent to which the alternatives described are realistic for determining the types and range of water-resources impacts.

Guided by the coal-resource development alternatives in table 1 , specific studies were conducted to assess the implications of discharged waste residuals and water use that might result from each alternative. Interactions between economic and environmental-control factors, water use, and demand for various forms of energy were considered in several of these analyses.

The studies were designed to answer questions such as the following: (1) What increases in population and changes in the basin economy are expected? (2) What are some of the water-use ramifications of this development (in terms of both withdrawals and consumption)? (3) Are these projections in conflict with existing water-use patterns in the basin? (4) What residual wastes will be discharged that may adversely affect the environment in general and the basin's water resources in particular? (5) Is enough water available, in either a physical or institutional sense, for projected uses in the basin? (6) How will the water resources change over time, in terms of water supply or water-quality characteristics? and (7) Should some limits be imposed to either the extent or the form of energyresource or related economic development?

Although complete answers to these questions were not provided in every instance, the questions themselves give some indication of the direction and scope of the studies addressed by the Yampa River basin assessment and summarized by this report. The assessment approaches were developed around a central theme of determining several of the possible environmental implications of the anticipated regional economic growth stimulated by accelerated mining of coal. Study results also indicate future information needs using physicalbased data, particularly related to regional water resources. With this information, planners and managers should be able to more effectively use the available natural resources in the region, given stated or implied resource-development and environmental goals.

\section{LEGAL ASPECTS OF WATER- RESOURCES DEVELOPMENT}

\author{
By WALTER I. KNUdSEN, Jr. ${ }^{1}$ \\ and JERIS A. DANIELSON ${ }^{1}$
}

There is much concern regarding the availability of water in the Yampa River basin for energyresource development. The supply of water for various specified uses is a function of its physical presence; its legal availability as dictated by interstate compacts, court decrees, and judicial constraints; and its economic value. Several factors affecting the legal availability of water in this region, from the standpoint of water law and securing and transferring water rights in Colorado, are described by Knudsen and Danielson (1977).

"First in time, first in right" is the popular phrase used to describe the doctrine of prior appropriation as it applies to water, particularly in the Yampa River basin. The western United States acquired the doctrine of prior appropriation from Spain via Mexico. Implementation of the doctrine initially involved only the principal uses of surface waters. As surface waters have become almost completely appropriated in many parts of the West, similar institutional controls were applied to ground-water resources. Most concerns during the next 15 years in the Yampa River basin involve increasing water demands and the extent to which surface waters physically and institutionally will be available to meet these demands. Longer term concerns involve availability and quality of ground water. The withdrawal of ground water has not yet

${ }^{1}$ Colorado Department of Natural Resources, Division of Water Resources, Office of the State Engineer. 
presented any major problems in the Yampa River basin. However, the doctrine of prior appropriation also applies to tributary ground water.

Surface water is available in widely varying quantities from year to year, and from location to location. Naturally occurring hydrologic variability often results in water shortages in certain areas or during certain times when and where demand for water exceeds the supply.

In the Yampa River basin as well as elsewhere in the Western States, a traditional means of water allocation involves use of a priority date. The priority date is that legally recognized point in time, as defined by State statute, when water was first put to beneficial use by someone seeking the adjudication of a water right. As long as there is sufficient water available to meet the demands of all water appropriators, few problems occur. When insufficient water exists to meet all demands at a given point in time, then the priority date is used to allocate the available water. Those priorities most recent in time (junior priorities) must allow sufficient surface water to pass by their points of diversion in order to let downstream priorities earlier in time (senior priorities) receive the water due them, according to their decree as adjudicated by the judicial system.

Another factor complicating water administration is a hierarchy of beneficial use. For most western States, these include, in descending order: domestic water supply, agricultural use, industrial use, and recreation. Recently, minimum-flow requirements for protection of aquatic life have been added to this ordering.

When allocating water in water-short areas, the use of water may be of a higher order than the priority date. However, statute and case law as developed from these provisions in the courts (at least in Colorado) has set the priority date as the primary means for allocating water in water-short areas with the provision that a higher order use, such as domestic, could acquire a lower order use, such as irrigation, through condemnation proceedings. For example, an irrigation water right with a priority date senior to a domestic water right will get its water first if there is not sufficient water to fill both decrees. However, the domestic right may acquire the irrigation right through condemnation proceedings and the payment of just compensation as determined by negotiation or judicial decree.
Water rights in Colorado are established through adjudication procedures in the judicial system, not through the State Engineer's Office. In Wyoming, the State Engineer oversees the adjudication of water. A water right is recognized as a property right and can be bought and sold the same as any other piece of property. At the same time, the water right must be used or it is subject to loss through established judicial procedure. A water right is decreed to a point of diversion-not to an individual-and it is decreed for a specific use or set of uses. Any change in use is subject to judicial review, which allows for protection of the rights of all appropriators-both senior and junior.

The judicial framework for administering water law is discussed by Knudsen and Danielson (1977) for Colorado and by the Wyoming State Engineer's Office (1970) for Wyoming. Case law has had a substantial effect upon water law and administration. Statutes alone cannot give total guidance in all situations where there have been and will be differences of opinion as to the statutes' meaning and intent. Case law affecting water rights normally arises from one of two types of litigation: that which is a direct challenge of statute; and that which evolves from civil suits, the end result of which directly affects water law. Some examples of interest are given by Knudsen and Danielson (1977).

The agriculturally oriented purpose for several projects proposed in the Yampa River basin by the U.S. Water and Power Resources Service (U.S. Bureau of Reclamation) has been reoriented towards energy-resource development (U.S. Bureau of Reclamation, 1974; Weatherford and Jacoby, 1975; Jacoby and others, 1976). These and other proposals consider the transfer of surface water out of the basin. In order to determine what the in-basin effect would be for a given project configuration, any such modification would require a reevaluation of the entire water-distribution system of the basin.

Two interstate compacts directly affect the amounts of water available for energy development in the Yampa River basin. The Colorado River Compact of 1922 (Colorado Revised Statutes, 1973, Art. 37-61) states that use of water in the Upper Colorado River Basin by the States of Colorado, Utah, Wyoming, and New Mexico will not cause the flow of the river at Lees Ferry, Ariz., to be depleted below an aggregate of 75 million acre- $\mathrm{ft}$ $\left(92.5\right.$ billion $\left.\mathrm{m}^{3}\right)$ in any successive 10 -year period. 
The Upper Colorado River Compact of 1948 (Colorado Revised Statutes, 1973, Art. 37-62), apportions the amount of water allocated to the Upper Basin States (Colorado, Wyoming, Utah, Arizona, and New Mexico) and also dictates the procedure to be used by the Upper Basin States to meet a demand for water by the Lower Basin States. Stipulations of this compact directly affecting the Yampa River basin involve the minimum release of water from the Yampa River near Maybell, Colo. (fig. 1), and the distribution of irrigation diversions of certain tributaries of the Little Snake River along the Colorado-Wyoming State line (Knudsen and Danielson, 1977).

On-stream reservoir operations, which may increase in the Yampa River basin, constitute a special case of water administration and management. This is partly due to the need to ensure that illegal storage of water does not occur. The criteria used to determine the reservoir outflow required to fulfill downstream senior water rights vary in accordance with local conditions and customs. The management of such stored water needs to be accomplished without jeopardizing senior water rights.

Numerous proposed reservoir projects in the Yampa River basin have been designed not only to appropriate additional waters of the Yampa River basin but also to rearrange, to some degree, the existing water-use patterns (Steele and others, 1979). Future water-development projects will be dependent on factors such as future land-use patterns in the area and the availability of water. The Yampa River basin and adjacent areas have an abundance of energy resources that will require substantial amounts of water for development (Holland, 1975; Van Zandt, 1975; Steele, 1976). If no unappropriated water is available following the implementation of the major proposed reservoirs mentioned above, future development may depend upon the acquisition of existing surface-water rights to meet anticipated water demands or on the development of ground-water resources. Changes in use and changes in points of diversion for water rights are granted by the courts, and each case is considered individually. It is difficult to give definitive guidelines for forecasting future actions by the courts in these matters. However, in any actions, adverse effects upon existing water rightsjunior or senior-are evaluated carefully by all affected parties.
In the Upper Colorado River Basin, some water traditionally used for irrigation is being transferred to industrial use through purchase and the appropriate judicial procedures (Colorado Department of Natural Resources, 1980). The circumstances surrounding such transfers vary from case to case. Irrigation is a seasonal use of water; an industry commonly requires a year-round use of a fixed amount of water. There is a difference in the consumptive uses of irrigation versus industry; that is, that portion of a water withdrawal that is totally consumed by the beneficial use and not returned to the river system. Generally, such transfers in water use are dependent on the degree of injury to vested rights, the historic diversion of the right to be transferred, consumptive use of the water, and other factors the water court or affected parties may introduce in the adjudication in a particular case.

With increased coal-resource and associated economic development, the competition for water in the basin is becoming greater and greater. In the event certain streams of the Yampa River basin become depleted to the point where Colorado or Wyoming can no longer meet their interstatecompact commitments in the Upper Colorado River Basin, the doctrine of prior appropriation will determine which junior decrees are to be denied water in order to fulfill these commitments. This could well involve junior decrees adjudicated to industrial companies for energy development or for allocating minimum flows to protect aquatic life.

In summary, water in the Yampa River basin is allocated by a combination of constitutionally recognized rights, State statutes, water-rights decrees, administrative practice, and case law as developed through litigation. In Colorado, the State Engineer administers the water of the State in accordance with water decrees adjudicated by the courts of the State. In Wyoming, the State Engineer has a direct role in administration of water rights. These factors, plus other changes to the physical system due to the addition or depletion of water, undoubtedly will interact with existing water rights and will affect subsequent use of water in the Yampa River basin. Physical-based water-resource studies need to consider these institutional factors.

No mention has been made up to this point of the numerous pieces of Federal water-pollution-control legislation having general or specific application to 
the Yampa River basin (Upper Colorado River Commission, 1965-77). Sections of the Federal Water Pollution Control Amendments Act of 1972 (Public Law-92-500) and the Colorado River Salinity Control Project Act (Public Law 93-320) have particular significance. The setting, review, and modification of stream and effluent standards by the States of Colorado and Wyoming also have relevant application. The interactions between water quantity and water quality entail several institutional difficulties, as demonstrated by time of passage of separate legislative articles and the specification of separate administrative bodies responsible for enactment of these articles. Many of these difficulties will be overcome with time and with the setting of precedents. However, within the context of this basin assessment, it is hoped that certain vested institutional interests can be made more interactive and that legislative incompatibilities can be resolved through rational discussion of both physical and economic implications.

\section{TECHNICAL INFORMATION IN PLANNING AND MANAGEMENT OF REGIONAL WATER- RESOURCES IN AREAS OF COAL-DEVELOPMENT POTENTIAL}

\author{
By IVAn C. James II and Phillip E. StarK'
}

Not until he reached a sod hut at the other end of the town did he make a bargain worth mentioning; here he happened on a widow with two half-grown boys; the widow was Danish and ran a small poultry farm.

***Yes, indeed, she needed potatoes, for both herself and the boys, and for the birds as well; she hadn't any money in the house, but she had the chickens.*** Wouldn't he trade some potatoes for a fowl or two?

-Of course he would: Per Hansa was more than willing; after dickering awhile, he bartered nine pails of potatoes for three young chickens.

-This is a mighty profitable deal-he thought-The Hallings are good people, but the Danes are even better.

***'Listen, Mother, perhaps you'd just as soon take three pailfuls more and give me the fourth hen?" ***The widow agreed to that at once and Per Hansa felt that now he had made a fine bargain indeed.

The widow, too, seemed very well satisfied; they beamed in mutual gratitude, filled with generous thoughts.

(Rölvaag, 1927)

'Former Director, Routt County Department of Environmental Health, Steamboat Springs, Colo.
In the rural Dakotas of the 1890's where this vignette occurred, the monetary economy was not well established. The bartering exemplified involved formalities and the investment of time and effort little used in today's market economy.

The bargaining that Per Hansa and the widow undertook is a microcosm of the much more complicated bargaining that takes place between various interest groups involved with energy development and water-resources planning. Perhaps the differences are even more striking than the similarities.

For Per Hansa and the widow, there was no question of property rights-he owned the potatoes, she the chickens-the question was the ratio at which they would be exchanged. If they could not come to an agreement, the trade would not be made, and they each would be no better off than before. Per Hansa may have been willing to trade up to four or five pails of potatoes for a chicken, and the widow may have taken as little as two; so even both were better off after the trade, their individual abilities to bargain may have determined how much better off.

Property rights of individuals to enjoy clean water and air, and the rights of productive enterprises to discharge residuals into the environment are less well defined than the rights that Per Hansa and the widow exercised through ownership. Lacking a market mechanism for their determination, prices for environmental amenities are usually not known. Permitting requirements allow for significant amounts of public involvement and political input to the process. A multiplicity of interests also distinguishes this process. It is oversimplifying to categorize the interest groups as either "prodevelopment" or "anti-development." Although such feelings may exist, other issues concerning the management of the social and environmental effects of energy development may be of even greater importance.

Although Per Hansa or the widow each could have prevented the completion of any trade, in the decisionmaking for energy-development the relative abilities of the various parties to effect, veto, or otherwise influence the decisionmaking process, in accordance with their desires, are not well defined. The myriad of requirements involved with the leasing, development, transportation, and conversion of energy gives many opportunities for review of the development process and also gives many points where opposing interests may express 
their opinions. Pro-development interests, however, also have the advantage of our traditional view, ensconced in law, that the use of private property is largely at the discretion of the owner, provided that requirements to protect the general health, safety, and well-being of society are observed. Thus, a somewhat balanced set of forces exists, with the sway affected by public opinion through its expression in the legislative and executive powers of government tempered by traditional and constitutional judiciary considerations.

Into this potentially adversary situation, the scientist comes forth with technical information and assessments on the likely impact of various alternative-development plans and mitigating programs. The sensitivity of the situation and the potential for this information to affect the decisionmaking process makes collection and analysis of the environmental information a potential threat from the viewpoint of the interested parties.

The fact often not realized by the contenders is the positive value that information can have for both of them in resolving their conflict. In contrast to Per Hansa and the widow, where the total quantity of potatoes and chickens was fixed and they were just bargaining for a mutually advantageous redistribution, the environmental-development conflict commonly has opportunities for resolution that are better for most of the interested parties.

Achieving such resolutions requires bargaining and a technical-information base to demonstrate to the interested parties the potential benefits and costs of the alternative actions being considered. Without a technical-information base, the relative benefits and costs of such disparate items as reclaimed land, nutrient concentrations in streamflow, municipal indebtedness, and environmental damages cannot be displayed. The potential for discovering those compromise solutions, that are viewed by the major interests as better than what might have been achieved without the information, remains unfulfilled.

Methods for making decisions concerning natural-resources development and the environmental consequences of such development vary from situation to situation, reflecting the influence of tradition, legal development, and extent of controversy over the issues to be determined. The failure of prescribed decisionmaking processes to reach a compromise acceptable to the major parties of interest may lead to an appeal of the decision to a higher administrative, legislative, or judicial authority, which has the effect of mixing the decisionmaking methods in a sequential manner. Another type of mixing occurs in cases where the decisionmaking takes place in many steps at different locations. Development of a mine-mouth electric powerplant requires decisionmaking at many political levels as described by Beckner (1976). Although decisionmaking usually cannot be simply described, there are several decisionmaking processes which may approximate particular situations or components of a larger planning process. The information requirements for each of these processes can be more easily and generally described than for the total decisionmaking process.

Many natural-resource decisions that would adversely impact the environment were virtually unopposed before the growth of environmentalism in the late 1960's. Opposition to decisions prior to that time often existed only locally and was not well organized; effective legal and procedural mechanisms were lacking. The public as a whole had more trust in government, more perceived need for economic development, and a feeling of inevitability of governmental and corporate plans. Because the decisionmaking was centered in the private sector or accomplished in government in a rather rigorously prescribed procedure and environmental effects were of less concern, the needs for technical information in the decision process were rather small. Environmental information (data and modeling) was used after the main decision was made, when ameliorating procedures such as streamflow augmentation for dilution of heat load and residual discharge were being considered.

Relatively limited information is also used in making decisions, the outcomes of which are determined by an administrative process. An example is the one-stop regulatory agency. Authority to grant permits, set rules, and establish standards, legislatively delegated to administrative agencies, is a rather commonly used decisionmaking mechanism in Federal and State governments.

For convenience, for maintenance of a mask of equity, and for minimizing the risks of judicial review, action agencies often favor uniformity in rulemaking and regulatory approach. It requires very little information and engenders less judicial risk to decree a uniform level of residuals modification, and requires much less information than is required to design a minimum cost regional 
residuals-management system to achieve a particular environmental objective. Conversely, an efficient approach to environmental management may require considerably larger efforts in understanding the response of the environment to the direct and indirect effects of various actions. The social benefits of customized residuals-management programs may be quite large, but the benefits of such approaches to the regulatory and legislative bodies apparently has not been great enough to warrant serious consideration in most cases.

At the legislative level of decisionmaking, conflicting viewpoints are brought to compromise by the usual techniques of representative governments; vote trading, logrolling, coercion, etc. (Haefele, 1971), in a decisionmaking process that can be characterized as political accommodation. This has a tendency to broaden the scope of tradeoffs to unrelated issues. The various sides to an issue may attempt to garner support via vote trading, which effectively extends coalitions into somewhat unusual areas of concern. By its involvement in decisionmaking, the legislative body may increase the number of parties to the decision and increase the scope of the options available. To achieve a resolution that both sides find acceptable, the legislative body may sweeten the compromise solution through the infusion of public funds to lessen adverse impacts.

The information requirements for political accommodation are considerably different than for other decisionmaking processes. Legislatures do not have the expertise or time to thoroughly understand the technicalities or details of the issues involved. Rather, they often rely on their clientele's desires rather than hard information as a basis for decisionmaking. What information they do utilize must, of necessity, be very compressed, simplified, and aggregated. Information in raw forms, or that is not distilled to its essence for the decision at hand, is not likely to be utilized.

Suggestions have been made by some-particularly economists - that the solution to environmental problems lies in a strict definition of property rights and the development of a marketing system in those rights. "Rights-topollute" could be established for particular receiving media and they could be exchanged like any other commodity. The well-known ability of the marketplace to, under certain conditions, optimally allocate resources could be used. A produc- tive process generating residuals could then make its optimal decision concerning the level of residuals modification and amount of "rights" to buy. Environmental interests could similarly enter the marketplace and bid on these rights and leave them unexercised. There are some very real problems with a system of decisionmaking by a marketplace process, particularly with respect to the public-goods nature of environmental amenities. The possibilities for efficiently achieving environmental objectives by such systems, however, has intrigued economists for some time. In this more restrictive application of the method, information is simply needed to arrive at the amount of "rights" to be established to meet the specified environmental objectives. This may simply be environmental results that link loadings to ambient environmental quality, or possibly also include economic analyses to estimate the optimal level of environmental quality, considering the costs of residuals treatment in relation to the benefits from improved environmental quality.

As the environmental decisionmaking process evolves, the amount, kind, and nature of the information supplied to it must change if it is to remain relevant. The use of technical information purely for design efficiency has given way to its use for assessing a wide range of cause-and-effects relationships related to energy development. Such assessments also must be evaluated by public and interest groups.

The less technically specialized individual needs to have the technical material presented in a form which is accurate yet comprehensible at his technical level. Communication of technical knowledge thus becomes more difficult and more important. Information and data developed from the Yampa River basin assessment have been and are being used for decisionmaking. Although the nature of the decisions being made may be somewhat unique to this basin and to the present condition of the environmental decisionmaking process, it may be informative to describe some of the specific uses that have been made of information developed in this study. The remainder of this chapter describes some examples of the uses of technical data and information.

As a result of recently adopted Federal surfacemining regulations (Public Law 95-87), local coalmine operators are using surface-water-quality data obtained during the assessment to fulfill cer- 
tain regulatory obligations, such as providing a surface-water-quality data base. Also, by comparing water-quality data obtained subsequent to the assessment with the assessment data, the coalmine operators are able to determine the effects of their activities on surface-water quality. Using the comparisons, the coal-mine operators are able to modify their activities, if needed, to minimize the effects of mining on surface-water quality. Regulatory agencies also are using both the surface-water-quality data provided by the coal companies and the assessment data to assess the impacts of mining on surface-water quality.

As of 1980 , projects to improve wastewatertreatment facilities, implemented under Section 208 of the Federal Water Pollution Control Act Amendments of 1972 (Public Law 92-500), have been completed or are in progress at Steamboat Springs (U.S. Environmental Protection Agency, 1977), at Oak Creek and at Hayden in Routt County, and at Craig in Moffat County (Norton, Underwood, and Lamb, Engineering Associates, 1978). Surface-water-quality data from the Yampa River basin assessment have been and are being used by planners and engineers associated with these projects to aid in the design of the wastewater-treatment facilities. The data also are being used to anticipate impacts of effluent discharged from the plants. Model results of the potential effects of the wastewater-treatment plant at Steamboat Springs (Bauer and others, 1978) indicated that certain standards for effluent did not need to be as stringent as originally proposed in order to meet specified water-quality goals. As a result, local governments modified the standards for effluent, which may have resulted in substantial cost savings for the project.

Surface-water-quality data also were used in the planning and feasibility reports prepared for a reservoir in Routt County (Woodard-Clyde Consultants, 1977). The data were used to establish water-quality characteristics prior to reservoir construction and to anticipate possible impacts of the reservoir on water quality in the Yampa River.

Results from both the waste-load assimilativecapacity analysis of the Yampa River (Bauer and others, 1978) and the reservoir-development analysis (D. B. Adams, D. P. Bauer, R. H. Dale, and T. D. Steele, written commun., 1978) have been used by local officials to determine the effects of augmenting minimum streamflow by reservoir releases. On the basis of these results, local officials have concluded that selected ambient waterquality characteristics may be improved by flow augmentation and that the impact of pollutants discharged to streams downstream from reservoirs can be reduced by flow augmentation.

Another aspect of the use of data from the Yampa River basin assessment involved the North West Colorado Council of Governments, a local multicounty governmental agency, that received funds under Section 208 of the Federal Water Pollution Control Amendments Act of 1972 (Public Law 92-500) to develop an area-wide water-quality-management plan. As stipulated in Section 208 of Public Law 92-500, the North West Colorado Council of Governments is to identify surfacewater-quality problems within the six-county area it represents and is to implement measures to eliminate existing problems and prevent future problems. As the goal of identifying existing waterquality problems was similar to that of the Yampa River basin assessment, cooperative program efforts were modified by the U.S. Geological Survey to fulfill the Section-208 requirements for waterquality information from Routt County (U.S. Geological Survey, 1976). As a result, data provided by the U.S. Geological Survey were suitable for use by the North West Colorado Council of Governments in its Section-208 planning endeavor (Britton, 1979). Thus, the two agencies were able to minimize duplication of effort by coordinating desired study products.

In summary, local officials are using data and information from several studies conducted during the Yampa River basin assessment. Information from this and related projects has allowed officials and managers to fulfill regulatory obligations and to predict some of the effects of planned development on the water resources of the region. Moreover, an attempt has been made to present the resultant information in a form that is understandable and applicable to regional problems. Technical studies in other energy-developing regions might well apply the reporting format used by this basin assessment. Information surveys conducted in the future will be the best judge of the extent to which attempts at communicating technical information have been successful and will indicate better ways to provide information for decisionmaking. 


\section{PART II. ASSESSMENT TECHNIQUES}

Given the previously described study framework, in terms of assumed development alternatives, institutional aspects of water availability, and the technical information needs for decisionmaking, a range of assessment techniques was applied to the Yampa River basin. The general implication is that the indicated set of studies, the results of which are highlighted in the following chapters, could serve as a general guide for similar assessments in other energy-developing regions of the West.

Details of study applications using these techniques are given in separate technical reports. In an attempt to demonstrate the interactions of the several study components and the need to consider these interactions, only selected results are highlighted here.

\section{REGIONAL ECONOMIC ANALYSIS FOR PREDICTING WATER USE AND WASTE RESIDUALS}

\section{By JOHN E. SCHEFTER}

The development and use of coal resources of the Yampa River basin will induce further economic activity within the region. The various sectors or industries of the regional economy do not operate in isolation; they are interdependent. Growth in one economic sector will result in an increase in its demand for inputs required to produce its product and, thus, will stimulate growth in the sectors providing those inputs. An increase in the production or output of these indirectly affected sectors will, in turn, stimulate output in other sectors. This increase in the output of the sectors of the regional economy generally will result in an overall increase in employment and population in the region, which will further stimulate growth in the various sectors. Because impacts of the development of coal resources will reverberate throughout the basin, the total (direct and indirect) increase in the output of the regional economy will be larger than just the direct increase in the value of the output of the coal-mining and coal-use sectors.

For any given rate of coal mining, the magnitude of the direct and indirect increase in the output of each sector, and the composition of the increase in the overall output of the regional economy, will de- pend upon how and where the coal is used. For example, the use of any given quantity of coal in a coal-gasification process is likely to have a different effect on the output of the various sectors than would the use of the same amount of coal in thermal-electric-power generation. They are different processes and thus require inputs from different sectors and different levels of inputs from the same sectors. Similarly, transport of coal out of the basin by coal-slurry pipeline is likely to have a different effect on the various sectors of the regional economy than would coal transported by unit train (Palmer and others, 1977). The direct and indirect effects of a given rate of coal mining on the output of the various sectors of the economy, and, thus, on the level and composition of the total output of the regional economy, can be expected to be greater if the coal is used within the basin, rather than transported out of the basin.

Each sector of the regional economy uses a different amount of water and generates different amounts and types of residuals per dollar of output. Thus, the rate of coal mining, the coalutilization process, and the method of transporting the coal out of the basin will affect rates of water use and the discharge of waste residuals within the basin.

Economic input-output analysis (Miernyk, 1965) provides a means of estimating the total (direct and indirect) changes in the output of each sector of the regional economy, given any specified change in the output of one or more of the energy-related (coal-mining, coal-conversion, or coal-transportation) sectors-or any other sector. Given coefficients which specify the amount of water used and residuals discharged per dollar of output for each sector, an input-output model can be used to predict the changes in water use and residuals discharged as a result of projected changes in economic activity (Gray and McKean, 1975; Howe and others, 1975). A description of an input-output model of the Colorado part of the Yampa River basin as approximated by Routt and Moffat Counties is given in Udis and Hess (1976), Udis, Adams, Hess, and Orr (1977), and Hirsch James, and Schefter (1978).

Input-output analysis provides linear approximations to the economic interactions between the sectors of an economy: outputs vary linearly with 
inputs and inputs are employed in fixed proportions. Also, water use, employment, and residuals discharge are assumed to vary linearly with output. The linearity inherent to input-output analysis is not particularly troublesome in the absence of relatively large expected or predicted changes in the output of any one sector. However, the technology used by energy-related sectors undergoing relatively large expansion may be expected to be substantially different from that currently used. Moreover, coal-resource development in the Yampa River basin may result in new types of industry coming into the region.

The input-output model of the Yampa River basin economy was designed to consider technological differences between the existing and potential new coal-mining, thermal-electric powerplant, and unit-train operations, and to consider the possibility that a coal-slurry pipeline and/or coal-gasification plants might be operated in the region. Three sectors were included in the model to represent expansion of surface mining of coal, underground mining of coal, and unit-train operations. An additional three sectors were included to represent (potential) thermal-electric powerplants, coal-gasification plants, and a coalslurry pipeline.

Plant-process models (I. C. James II, E. D. Attanasi, T. Maddock III, S. H. Chiang, B. T. Bower, and N. C. Matalas, written commun., 1978) were used to derive estimates of the direct productionrequirement coefficients for the new and expansion sectors. These coefficients give the inputs directly required by the new and expansion sectors, per dollar of output, from all other sectors of the regional economy.

To provide estimates of water withdrawal in the Yampa River basin under several energydevelopment alternatives, it was necessary to derive estimates of water withdrawal per dollar of output for each sector of the economy. For most of the existing sectors (32 and 45 in table 2), waterwithdrawal coefficients were derived by estimating the total quantity of water withdrawn by each of the sectors in 1975, and dividing this total by the dollar value of the output of the corresponding sector during that year. Water-withdrawal coefficients for the new and expansion sectors were primarily derived using plant-process models (I. C. James II, E. D. Attanasi, T. Maddock III, S. H. Chiang, B. T. Bower, and N. C. Matalas, written commun., 1978; Hirsch, 1979). New electric powerplants were assumed to use wet-cooling towers. Estimates of water-withdrawal coefficients and of the quantity of water withdrawn by each sector in 1975 are presented in table 2.

Also presented in table 2 are the waterwithdrawal multipliers as estimated using the input-output model. Whereas the water-withdrawal coefficient for a sector is an estimate of the direct water-withdrawal per dollar of output, the water-withdrawal multiplier is an estimate of the total (direct and indirect) water withdrawal by all sectors of the regional economy per dollar of output delivered to final demand (that is, ultimately consumed in or exported from the basin) by the sector in question. For example, if a new thermal-electric powerplant (sector 35) is to generate one dollar's worth of electricity for export from the basin, it will directly require that about 99 gallons $(375 \mathrm{~L})$ of water be withdrawn. But, it is estimated that due to indirect effects (including increased mining of coal to fuel the powerplant) the export of the dollar's worth of electricity will directly and indirectly result in the withdrawal of a total of about 118 gallons (447 L) of water.

Though not presented here, estimates of the water-consumption coefficients also were derived, along with estimates of the water-consumption multipliers and total water consumption in the basin in 1975. These estimates are presented in Hirsch, James, and Schefter (1978, table 5).

It is estimated that the livestock sector in 1975 withdrew and consumed, by far, the most water - primarily for the irrigation of pastures and hayfields. But the existing electric-energy (27) and surface coal-mining (6) sectors were estimated to rank second and fourth, respectively, in the quantity of water withdrawn in the basin in 1975 (table 2).

Estimates were derived of the quantity of 13 types of residuals discharged per dollar of output by various sectors. For the energy-related sectors, these residuals coefficients were derived primarily using plant-process models (I. C. James II, E. D. Attanasi, T. Maddock III, S. H. Chiang, B. T. Bower, and N. C. Matalas, written commun., 1978). The residuals coefficients for the expanded surface-mining sector were derived under the assumption that the coal would be mined under a moderate to high level of land reclamation to reduce wind- and water-borne sediment (I. C. James II, E. D. Attanasi, T. Maddock III, S. H. Chiang, B. T. Bower, and N. C. Matalas, written commun., 1978). For other sectors, the estimates of 
TABLE 2.-Estimates of water-withdrawal coefficients, water-withdrawal multipliers, and total water withdrawal, by' sector, for the Colorado part of the Yampa River basin in 1975

\begin{tabular}{|c|c|c|c|c|}
\hline \multirow{2}{*}{\multicolumn{2}{|c|}{ Sector }} & \multicolumn{3}{|c|}{ Water wi thdrawal } \\
\hline & & \multirow{2}{*}{$\begin{array}{l}\text { Coefficient } \\
\qquad \text { (Gallons } \\
\text { per dollar) }\end{array}$} & \multirow{2}{*}{$\begin{array}{l}\text { Multiplier } \\
\text { (Gallons } \\
\text { per dollar) }\end{array}$} & \multirow{2}{*}{$\begin{array}{c}\text { Total } \\
\text { (Acre-feet) }\end{array}$} \\
\hline No. & Title & & & \\
\hline $\begin{array}{l}1 . \\
2 . \\
3 . \\
4 . \\
5 .\end{array}$ & $\begin{array}{l}\text { Livestock } \\
\text { Irrigated agriculture } \\
\text { Other agriculture } \\
\text { Forestry } \\
0 \mathrm{il} \text { and gas }\end{array}$ & $\begin{array}{r}4,808.0 \\
4,113.0 \\
.2 \\
8.0 \\
34.0\end{array}$ & $\begin{array}{r}5,228.8 \\
4,173.3 \\
152.8 \\
15.1 \\
36.8\end{array}$ & $\begin{array}{r}387,437.9 \\
4,250.0 \\
2.6 \\
12.9 \\
1,470.0\end{array}$ \\
\hline $\begin{array}{l}6 . \\
7 . \\
8 . \\
9 . \\
10\end{array}$ & $\begin{array}{l}\text { Surface coal mining } \\
\text { Underground coal mining } \\
\text { Other mining } \\
\text { 0ilfield services } \\
\text { Coal-mining services }\end{array}$ & $\begin{array}{r}25.4 \\
.0 \\
112.0 \\
33.0 \\
25.0\end{array}$ & $\begin{array}{r}33.2 \\
6.8 \\
117.8 \\
33.5 \\
25.6\end{array}$ & $\begin{array}{r}2,700.9 \\
.0 \\
236.8 \\
804.5 \\
673.6\end{array}$ \\
\hline $\begin{array}{l}11 . \\
12 . \\
13 . \\
14 . \\
15\end{array}$ & $\begin{array}{l}\text { Food and associated products-- } \\
\text { Lumber and wood products } \\
\text { Printing and publishing } \\
\text { Stone, clay, and glass } \\
\text { Other manufacturing }\end{array}$ & $\begin{array}{r}6.0 \\
27.0 \\
.7 \\
52.0 \\
10.9\end{array}$ & $\begin{array}{r}1,393.0 \\
39.0 \\
7.7 \\
58.6 \\
18.8\end{array}$ & $\begin{array}{r}37.1 \\
185.6 \\
1.0 \\
83.3 \\
27.8\end{array}$ \\
\hline $\begin{array}{l}16 . \\
17 . \\
18 . \\
19 . \\
20\end{array}$ & $\begin{array}{l}\text { Service stations--bulk dealers-- } \\
\text { 0ther wholesale establishments-- } \\
\text { Eating and drinking places- } \\
\text { All other service stations- } \\
\text { All other retail services-- }\end{array}$ & $\begin{array}{r}1.7 \\
2.8 \\
11.5 \\
2.2 \\
3.8\end{array}$ & $\begin{array}{r}6.7 \\
10.5 \\
46.2 \\
14.2 \\
10.9\end{array}$ & $\begin{array}{r}15.6 \\
32.3 \\
152.0 \\
9.7 \\
175.8\end{array}$ \\
\hline $\begin{array}{l}21 . \\
22 \\
23 \\
24 \\
25\end{array}$ & $\begin{array}{l}\text { Lodging } \\
\text { Recreation } \\
\text { Winter sports } \\
\text { Other nonprofessional services- } \\
\text { Railroad transportation- }\end{array}$ & $\begin{array}{l}2.8 \\
2.8 \\
3.4 \\
6.2 \\
1.0\end{array}$ & $\begin{array}{r}11.2 \\
21.4 \\
17.6 \\
12.1 \\
7.9\end{array}$ & $\begin{array}{r}40.2 \\
83.1 \\
39.1 \\
155.2 \\
56.1\end{array}$ \\
\hline $\begin{array}{l}26 . \\
27 . \\
28 . \\
29 . \\
30 .\end{array}$ & $\begin{array}{l}\text { All other transportation- } \\
\text { Electric energy- } \\
\text { All other utilities } \\
\text { Contract construction--light- } \\
\text { Contract construction--heavy-- }\end{array}$ & $\begin{array}{r}5.2 \\
98.8 \\
2.3 \\
6.8 \\
3.2\end{array}$ & $\begin{array}{r}24.3 \\
123.1 \\
6.8 \\
11.9 \\
7.0\end{array}$ & $\begin{array}{r}82.9 \\
5,427.3 \\
18.1 \\
58.6 \\
104.9\end{array}$ \\
\hline $\begin{array}{l}31 \\
32 \\
33 \\
34 \\
35\end{array}$ & $\begin{array}{l}\text { Rentals and finance } \\
\text { Local government } \\
\text { Expanded SFC coal operations } \\
\text { Expanded UG coal operations } \\
\text { New powerplant operations }\end{array}$ & $\begin{array}{r}4.9 \\
.7 \\
25.4 \\
.0 \\
98.8\end{array}$ & $\begin{array}{r}19.0 \\
8.1 \\
28.4 \\
9.2 \\
118.3\end{array}$ & $\begin{array}{r}860.8 \\
30.0 \\
.0 \\
.0 \\
.0\end{array}$ \\
\hline $\begin{array}{l}36 . \\
37 . \\
38\end{array}$ & $\begin{array}{l}\text { Coal-gas plant operations- } \\
\text { Slurry-pipeline operations } \\
\text { Unit-train operations }\end{array}$ & $\begin{array}{r}36.3 \\
393.0 \\
.0\end{array}$ & $\begin{array}{r}51.3 \\
426.9 \\
3.4\end{array}$ & $\begin{array}{l}.0 \\
.0 \\
.0\end{array}$ \\
\hline 45. & Households & 6.4 & 17.2 & $1,519.0$ \\
\hline & $\begin{array}{l}\text { Total water withdrawals (in } \\
\text { (acre-feet). }\end{array}$ & & & $406,784.8$ \\
\hline
\end{tabular}


the residuals coefficients were derived using a variety of sources.

Not all of the estimates of residuals discharge were linked solely to the value of the output of the various sectors. Some also were based on estimates of residuals discharged per person and, thus, were linked to the regional population. For example, the quantity of biochemical oxygen demand was linked both to the dollar value of the output of the livestock sector and the population of the region.

Population estimates for the Yampa River basin were based on estimated employment in each sector. The employment estimates were, in turn, based on sector-employment coefficients, which are estimates of the number of persons employed per dollar of output by each sector. Due to space limitations, the estimated employment coefficients, residuals coefficients, and the corresponding multipliers for each sector are not presented herein.

The input-output model was used to predict the impacts of alternative methods and rates of coal use on several aspects of the basin's environment. In making these predictions, the output of the existing coal-mining and electric-energy sectors (sectors 6,7 , and 27 , table 2) was constrained to 1975 levels. All additional coal mining and utilization is assumed to occur in the new and expansion sectors (33 through 38, table 2).

Predictions were made using two sets of scenarios. In the first set of four scenarios, it was assumed that an additional 12.5 million tons (11.3 million $\mathrm{t}$ ) of coal, above the estimated 4.6 million tons (4.2 million t) extracted in 1975 , is to be surface mined. The second set of seven scenarios (the coal-resource development alternatives presented in table 1) is intended to encompass the range of anticipated coal-resource development in the basin.

The four scenarios were employed to obtain across-use comparisons of the impacts of using the additional coal in each of four ways.

1. All of the additional coal is used within the basin by thermal-electric powerplants to generate electricity, solely for export from the basin.

2. All of the additional coal is used within the basin by coal-gasification plants to manufacture gas for export from the basin.

3. All of the additional coal is exported from the basin via a coal-slurry pipeline.

4. All of the additional coal is exported from the basin via unit trains.
In this first set of scenarios, any required construction under each of the alternatives has been assumed to be completed and the economy is assumed to be in a relatively steady state. This, of course, ignores part of the problem, as many severe, though relatively short-lived, impacts of energy development may occur during. the construction phase (Luken, 1974).

Estimates of population, water withdrawal and consumption, and residuals discharge under each of the scenarios are presented in table 3. Estimates also are presented for the existing (1975) level of development.

The two scenarios under which coal is used within the basin give rise to the most economic development, which results in the greatest increase in population, residuals output, and water use. The export of coal from the basin for use elsewhere, as in the other two scenarios, does not, of course, eliminate either residuals output or water use-it only "exports" these problems along with the coal.

If a goal is to increase the level of economic activity in the Yampa River basin, then coalgasification plants could be considered, for they produce the greatest increase of the four scenarios (table 3). On the other hand, if a goal is to remove coal resources with the least disruption to the existing conditions in the region (at least to those aspects considered), then either unit trains or a coal-slurry pipeline appear to be better alternatives (table 3).

The coal-slurry pipeline would consume, directly and indirectly, more water than would unit trains. The estimates of residuals discharge associated with the coal-slurry pipeline, however, are less than or equal to those in the unit-train scenario, for most types of residuals considered. Moreover, estimates were not made of noise pollution and of "damages" imposed on motorists who must wait at railroad crossings for unit trains to pass. These problems associated with unit trains may be of significant magnitude if trains are frequently used.

Though all water used directly by a coal-slurry pipeline would be consumed through export from the basin, the total rate of consumption under the pipeline alternative would be considerably less than that for either the thermal-electric powerplant or coal-gasification-plant scenarios.

The total impacts of energy development under each scenario are divided into percentage direct and percentage indirect in table 4 . It can be seen that plant-process models, which estimate only direct impacts, provide nearly the same, but lower 
TABLE 3.-Comparison of the impact of four alternative coal-use processes on selected aspects of the environment, Colorado part of the Yampa River basin

\begin{tabular}{|c|c|c|c|c|c|}
\hline \multirow[b]{2}{*}{ Item } & \multirow{2}{*}{$\begin{array}{c}\text { Existing } \\
(1975)\end{array}$} & \multicolumn{4}{|c|}{$\begin{array}{l}\text { Process using } \\
12.5 \text { million tons of coal }\end{array}$} \\
\hline & & $\begin{array}{l}\text { Electric } \\
\text { power- } \\
\text { plant }\end{array}$ & $\begin{array}{l}\text { Coal- } \\
\text { gasifi- } \\
\text { cation } \\
\text { plant }\end{array}$ & $\begin{array}{l}\text { Slurry- } \\
\text { pipeline } \\
\text { export }\end{array}$ & $\begin{array}{l}\text { Unit- } \\
\text { train } \\
\text { export }\end{array}$ \\
\hline Population- & 17,897 & 23,203 & 27,505 & 20,058 & 19,806 \\
\hline Water withdrawals (acre-ft per year)-- & 406,785 & 464,227 & 442,550 & 424,284 & 415,021 \\
\hline Water consumption (acre-ft per year)-- & 142,267 & 197,999 & 175,518 & 158,598 & 149,392 \\
\hline $\begin{array}{l}\text { Residuals discharged (tons per year): } \\
\text { Solid: }\end{array}$ & & & & & \\
\hline $\begin{array}{l}\text { Ash } \\
\text { Other solids }\end{array}$ & $\begin{array}{l}73,926 \\
25,666\end{array}$ & $\begin{array}{l}733,725 \\
142,009\end{array}$ & $\begin{array}{l}723,036 \\
178,210\end{array}$ & $\begin{array}{l}73,926 \\
27,243\end{array}$ & $\begin{array}{l}73,926 \\
27,059\end{array}$ \\
\hline $\begin{array}{l}\text { Ai rborne: } \\
\text { Total suspended particulates } \\
\text { Hydrocarbons } \\
\text { Nitrogen oxides } \\
\text { Sulfur oxides } \\
\text { Carbon monoxide- }\end{array}$ & $\begin{array}{r}122,225 \\
5,682 \\
22,193 \\
11,635 \\
7,790\end{array}$ & $\begin{array}{r}135,810 \\
7,371 \\
147,366 \\
55,479 \\
12,983\end{array}$ & $\begin{array}{r}130,529 \\
6,518 \\
47,784 \\
17,559 \\
9,227\end{array}$ & $\begin{array}{r}128,852 \\
5,756 \\
22,310 \\
11,665 \\
7,880\end{array}$ & $\begin{array}{r}131,721 \\
5,875 \\
22,490 \\
11,827 \\
8,054\end{array}$ \\
\hline $\begin{array}{l}\text { Waterborne: } \\
\text { Biochemical oxygen demand } \\
\text { Chemical oxygen demand } \\
\text { Nitrogen } \\
\text { Phosphorus } \\
\text { Suspended solids } \\
\text { Dissolved solids }\end{array}$ & $\begin{array}{r}2,152 \\
7,145 \\
130 \\
199 \\
13,276 \\
62,790\end{array}$ & $\begin{array}{r}2,180 \\
7,152 \\
141 \\
203 \\
38,312 \\
63,026\end{array}$ & $\begin{array}{r}2,202 \\
7,158 \\
151 \\
206 \\
38,340 \\
63,220\end{array}$ & $\begin{array}{r}2,163 \\
7,148 \\
134 \\
200 \\
38,291 \\
62,888\end{array}$ & $\begin{array}{r}2,162 \\
7,147 \\
134 \\
200 \\
38,289 \\
62,876\end{array}$ \\
\hline
\end{tabular}

estimates of water use and certain process-relatedresiduals discharge (ash, other solids, total suspended particulates, hydrocarbons, nitrogen oxides, sulfur oxides, carbon monoxide, and suspended solids) as the input-output model. However, plant-process models used without the input-output model would greatly underestimate the change in population-related (indirect) residuals discharge (biochemical oxygen demand, chemical oxygen demand, nitrogen, phosphorus, and dissolved solids).

The second set of scenarios encompass the seven coal-resource development alternatives of table 1 . Table 5 lists the estimates of population, water use, and residuals discharge under each of these seven scenarios, or coal-resource development alternatives. As these alternatives are intended to encompass the range of coal-resource development in the basin, both the rate of coal extraction and the method of utilizing the coal varies between scenarios. As a consequence, the estimates presented in table 5, though largely selfexplanatory, do not easily yield generalizations as to relative impacts of different rates of mining or uses of the coal. They should be considered to be only conditional, if-then, predictions of the impact of coal-resource development.

In summary, the ranges of projected economic activity in coal-resource development for the Yampa River basin were used to estimate future water demands and discharged waste residuals. While considerable uncertainty is inherent in any one of these projections, this technique does provide some estimate of relative magnitudes and types of stresses on the basin's environment. The estimates of the quantity of different types of 
TABLE 4.-Direct and indirect impacts, as a percentage of total impacts, of four different coal-use processes, Colorado part of the Yampa River basin

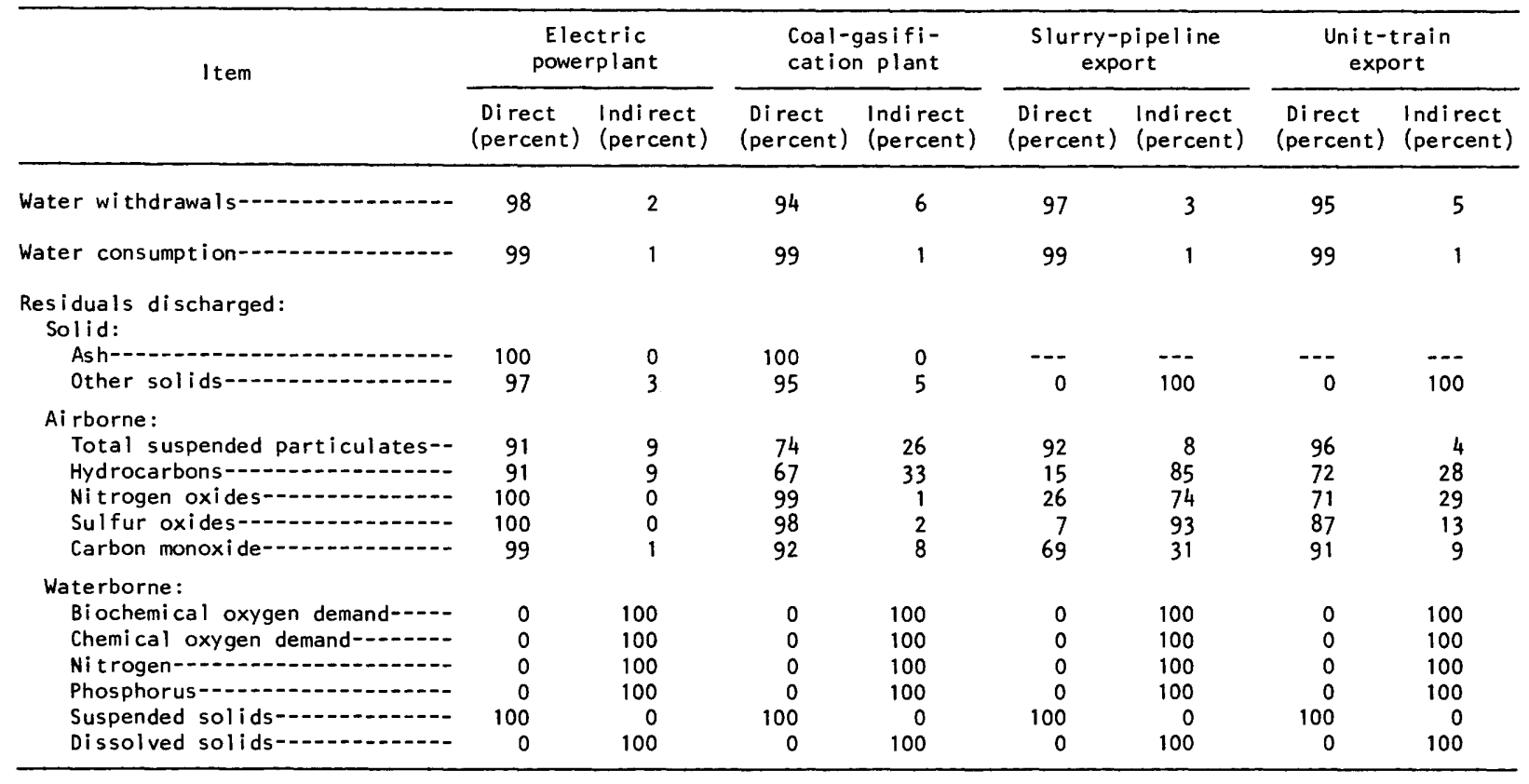

TABLE 5.-Water-use and residuals discharge under seven coal-resource development alternatives-1990

[Code designation and composition of alternative is given by Udis, Adams, Hess, and Orr 1977. Slow Growth, 10 million tons; moderate growth, 20 million tons; rapid growth, 30.8 million tons]

\begin{tabular}{|c|c|c|c|c|c|c|c|c|}
\hline & $\begin{array}{l}1975 \\
\text { base }\end{array}$ & \multicolumn{7}{|c|}{ Coal-resource development alternative } \\
\hline $\begin{array}{l}\text { Water use (acre-ft per year): } \\
\text { Withdrawal- } \\
\text { Consumption- }\end{array}$ & $\begin{array}{l}406,785 \\
142,267\end{array}$ & $\begin{array}{l}420,135 \\
154,804\end{array}$ & $\begin{array}{l}425,960 \\
159,486\end{array}$ & $\begin{array}{l}453,490 \\
185,612\end{array}$ & $\begin{array}{l}442,493 \\
175,818\end{array}$ & $\begin{array}{l}449,906 \\
183,183\end{array}$ & $\begin{array}{l}536,965 \\
267,979\end{array}$ & $\begin{array}{l}506,639 \\
237,489\end{array}$ \\
\hline $\begin{array}{l}\text { Residuals discharge (tons per year) } \\
\text { Solid: } \\
\text { Ash- } \\
\text { Other solids }\end{array}$ & $\begin{array}{l}73,926 \\
12,601\end{array}$ & $\begin{array}{r}214,331 \\
36,535\end{array}$ & $\begin{array}{r}214,331 \\
36,535\end{array}$ & $\begin{array}{l}863,441 \\
182,065\end{array}$ & $\begin{array}{r}436,024 \\
74,325\end{array}$ & $\begin{array}{r}436,024 \\
74,325\end{array}$ & $\begin{array}{r}1,618.383 \\
275,870\end{array}$ & $\begin{array}{r}1,351,758 \\
247,862\end{array}$ \\
\hline $\begin{array}{l}\text { Ai rborne: } \\
\text { Total suspended particulates-- } \\
\text { Hydrocarbons } \\
\text { Nitrogen oxides } \\
\text { Sulfur oxides } \\
\text { Carbon monoxide- }\end{array}$ & $\begin{array}{r}122,225 \\
5,682 \\
22,193 \\
11,635 \\
7,790\end{array}$ & $\begin{array}{r}126,077 \\
6,103 \\
48,915 \\
20,992 \\
8,926\end{array}$ & $\begin{array}{r}133,076 \\
6,311 \\
49,224 \\
21,167 \\
9,147\end{array}$ & $\begin{array}{r}132,546 \\
6,983 \\
74,562 \\
26,936 \\
10,361\end{array}$ & $\begin{array}{r}134,448 \\
6,813 \\
91,182 \\
35,834 \\
10,804\end{array}$ & $\begin{array}{r}133,218 \\
6,765 \\
91,108 \\
35,765 \\
10,729\end{array}$ & $\begin{array}{r}150,856 \\
9,785 \\
315,393 \\
114,334 \\
19,969\end{array}$ & $\begin{array}{r}145,425 \\
8,715 \\
216,075 \\
78,022 \\
16,068\end{array}$ \\
\hline 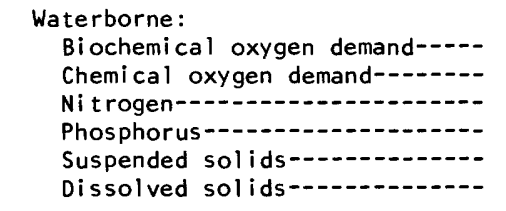 & $\begin{array}{r}2,152 \\
7,145 \\
130 \\
199 \\
13,276 \\
62,790\end{array}$ & $\begin{array}{r}2,169 \\
7,149 \\
136 \\
201 \\
20,636 \\
74,991\end{array}$ & $\begin{array}{r}2,188 \\
7,155 \\
145 \\
204 \\
36,661 \\
89,604\end{array}$ & $\begin{array}{r}2,228 \\
7,166 \\
162 \\
210 \\
36,712 \\
89,949\end{array}$ & $\begin{array}{r}2,194 \\
7,156 \\
147 \\
205 \\
36,668 \\
89,655\end{array}$ & $\begin{array}{r}2,195 \\
7,157 \\
148 \\
205 \\
36,670 \\
89,665\end{array}$ & $\begin{array}{r}2,245 \\
7,170 \\
169 \\
213 \\
54,016 \\
105,708\end{array}$ & $\begin{array}{r}2,250 \\
7,171 \\
171 \\
214 \\
54,021 \\
105,744\end{array}$ \\
\hline
\end{tabular}

residuals discharged to the atmosphere and the hydrologic system of tables 3 and 5 require further analysis before impacts on air and water quality can be predicted. 


\section{WATER-USE AND RESIDUALS IMPLICATIONS OF COAL-CONVERSION AND TRANSPORTATION ALTERNATIVES}

\author{
By ROBERT M. HIRSCH
}

Each coal-use alternative has a set of implications regarding discharge of residuals into the environment and use of water (Gold and others, 1977). In this chapter, a comparative analysis is made of alternative cooling systems in powerplants. Then, assuming a fixed amount of coal production, relative water-use implications are compared in use of this coal for electric-power generation, coal gasification, or a coal-slurry pipeline. Finally, a comparison of total residuals discharged as a result of the seven assumed coaldevelopment plans gives some insight into the possible environmental problems confronting resource managers in the Yampa River basin.

A coal-burning powerplant generating electricity must reject a vast amount of waste heat into the environment. For every megawatt-hour (MWh) of electricity produced, approximately 6.2 million Btu (6.5 billion joules) of heat is produced. There are five major methods available for dealing with this residual. Four of these methods-once-through cooling, cooling ponds, wet-cooling towers, and dry-cooling towers-were investigated to determine their implications for the use of water and energy as well as for the residuals produced in the heatproduction process. A fifth method not examined here is the beneficial use of waste heat.

The relative amounts of the heat load rejected by each mechanism are dependent upon: (1) the type of cooling device used; (2) climatic conditions (temperature, humidity, and wind); (3) hydrologic conditions (quantity and temperature of available water); and (4) certain plant-operating conditions.

The first three of these methods rely, to varying degrees, on evaporation as a cooling mechanism. For each kilogram of water evaporated, a water body loses 2,400 Btu (2.5 million joules) of heat. As a consequence of this evaporation, there is not just an addition of moisture to the atmosphere and loss of surface water available for other uses, but there also will be an increase in the concentration of dissolved and suspended solids in the remaining water. Thus, the consequences of heat-rejection methods involve changes in atmospheric conditions, water availability, and water quality.

Schematics of the four cooling systems considered in this analysis are shown in figure 3 . In the comparative analysis, the results of which are summarized in table 6, it was assumed that the cooling systems would be installed at a complex of powerplants using 12.5 million tons ( 11.3 million $\mathrm{t}$ ) of coal annually and that the total plant-generating capacity would be about $4,000 \mathrm{MW}$, with operating efficiency of 39 percent and a load factor of 83 percent (I. C. James II, E. D. Attanasi, T. Maddock III, S. H. Chiang, B. T. Bower, and N. C. Matalas, written commun., 1978).

For once-through cooling, the annual flow diverted from the river would average $3,580 \mathrm{ft}^{3} / \mathrm{s}$ $\left(101 \mathrm{~m}^{3} / \mathrm{s}\right)$ or total 2.15 million acre-ft (2.65 billion $\mathrm{m}^{3}$ ) (table 6). This water would be pumped from the river, passed through the powerplant condensers where it would be heated, and then returned to the river (fig. 3A). Because the three physical mechanisms of heat loss (evaporation, conduction, and long-wave radiation) proceed at rates which are increasing functions of water temperature, the river would begin to cool and gradually return to its natural temperature. In the reach of the river affected by this elevated temperature, there would likely be changes in the number and variety of aquatic species.

Because the evaporation rate of a free-water surface is an increasing function of water temperature, the evaporation rate for the river will be larger than it would be if no waste heat had been discharged to the river. The rate of water evaporation attributable to the powerplant is this difference between the actual rate and the natural rate of evaporation, integrated over the surface area of the river. The rate of water evaporation is an increasing function of wind speed, natural water temperature, and altitude.

By computing the rate of water evaporation for the various climatic and hydrologic conditions assumed to exist throughout the year, the annual evaporation by a hypothetical 4,000-MW powerplant located on the Yampa River would be 27,800 acre-ft ( 34.3 million $\mathrm{m}^{3}$ ), or 1 percent of the annual withdrawal rate (table 6). This would result in a 2.7-percent decrease in the mean annual flow of the 

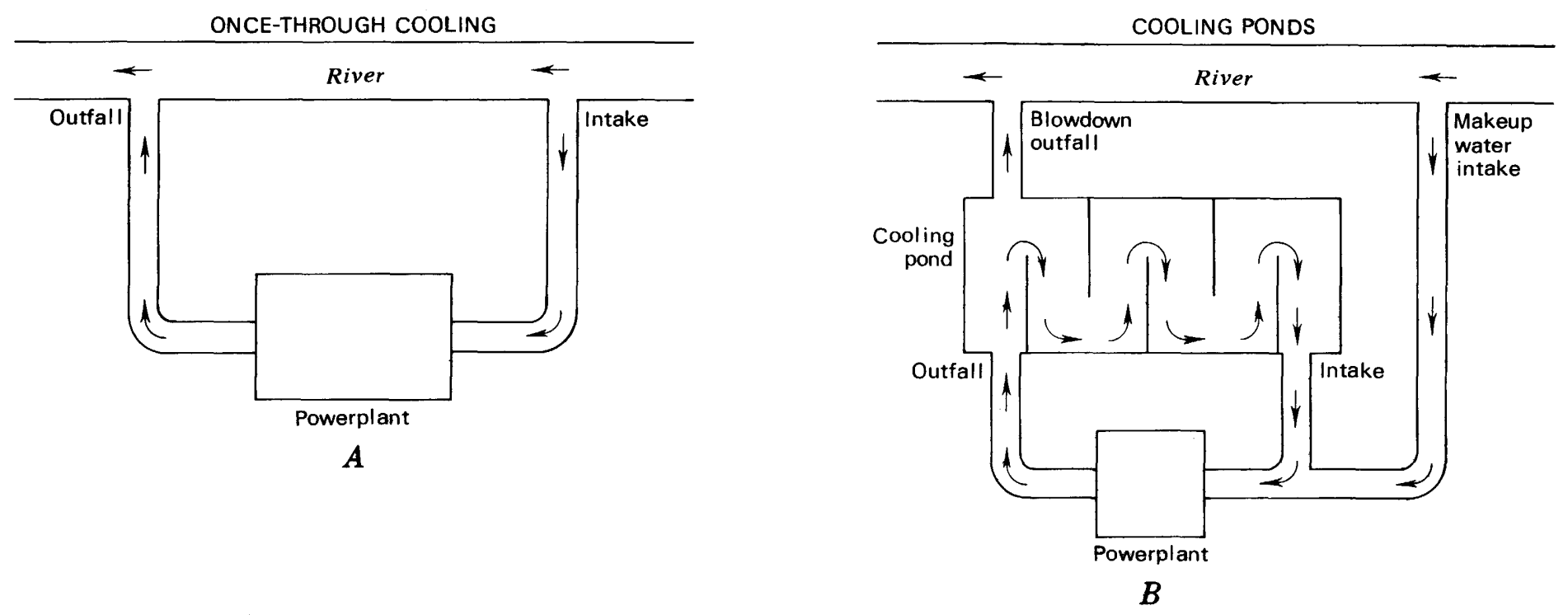

WET-COOLING TOWERS
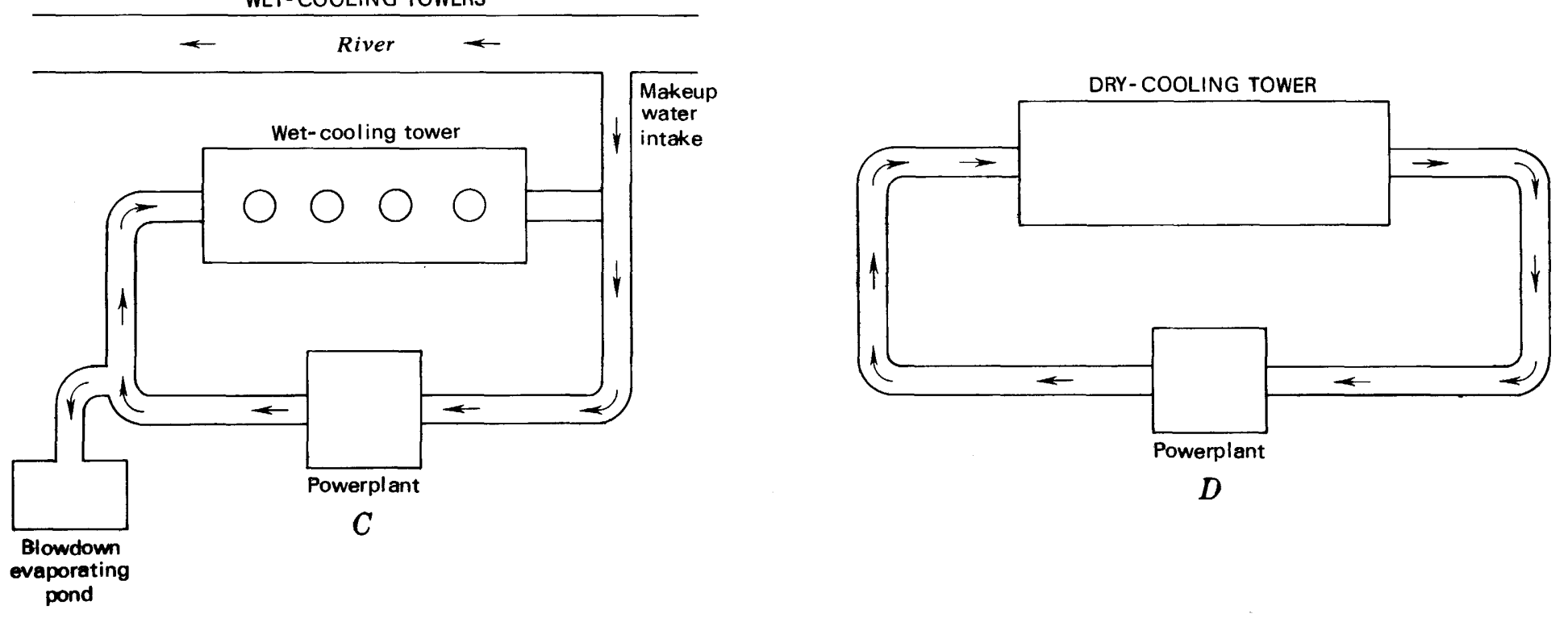

FIGURE 3.-Schematic diagrams of four cooling systems. (From Hirsch and others, 1978.) 
TABLE 6.-Comparison of four cooling technologies assuming mining of 12.5 million tons (11.3 million $t$ ) of coal per year

\begin{tabular}{lcccc}
\hline & $\begin{array}{c}\text { Once- } \\
\text { through }\end{array}$ & Pond & Wet & Dry \\
& $2,150,000$ & 45,700 & 44,400 & tower \\
\hline $\begin{array}{l}\text { Water withdrawn } \\
\text { (acre-feet per year). }\end{array}$ & & & & 0 \\
\hline $\begin{array}{l}\text { Water evaporated } \\
\text { (acre-feet per year). }\end{array}$ & 27,800 & 41,500 & 44,400 & 0 \\
\hline $\begin{array}{l}\text { Electric energy produced } \\
\text { (kilowatt-hours per year). }\end{array}$ & $32.6 \times 10^{9}$ & $32.6 \times 10^{9}$ & $32.4 \times 10^{9}$ & $30.3 \times 10^{9}$ \\
\hline $\begin{array}{l}\text { Dissolved-solids load in the } \\
\text { Yampa River (tons per year). }\end{array}$ & 218,800 & 218,800 & 210,400 & 218,800 \\
\hline $\begin{array}{l}\text { Discharge-weighted dissolved- } \\
\text { solids concentration in the } \\
\text { Yampa River near Maybell } \\
\text { (station 09251000) (milli- } \\
\text { grams per liter). }\end{array}$ \\
\hline
\end{tabular}

Average annual flow of the $\quad 1,087,000 \quad 1,074,000 \quad 1,071,000 \quad 1,115,000$

Yampa River at Maybell

(acre-feet per year).

Yampa River near Maybell, Colo. (fig. 2).

In the evaporation process, the dissolved solids in the river would remain in the water and, thus, their concentration would increase. Based on an existing discharge-weighted mean annual dissolved-solids concentration of $140 \mathrm{mg} / \mathrm{L}$ for the Yampa River near Maybell, Colo. (Iorns and others, 1965), the average dissolved-solids concentration would increase by an estimated $3 \mathrm{mg} / \mathrm{L}$ to $143 \mathrm{mg} / \mathrm{L}$ (table 6).

The water-withdrawal rates for once-through cooling are so great as to render this cooling method technically infeasible for a 4,000-MW powerplant in the Yampa River basin, according to an analysis by Maddock and Matalas (1980). However, it is worthy of mention, because it would be feasible on 
either a smaller scale or combined with one of the other technologies. Once-through cooling is a technology with some favorable aspects (small rates of evaporation, small capital cost, and small plant-efficiency losses), as well as some unfavorable aspects (damage to organisms from the pumps and condensers and ecological changes due to increased water temperatures). It is included in this analysis to facilitate the comparison of a range of development alternatives. In this manner, combinations of those options can be determined, which would be a realistic compromise among various economic, environmental, and social objectives.

For the second analysis, the cooling mechanism was assumed to be a cooling pond in the shape of a long sinuous canal covering 4,230 acres (1,710 ha) (fig. 3B). By simulation of the cooling process in this pond, considering the range of conditions prevailing in the Yampa River basin, the estimated annual evaporation from the pond would be 41,500 acre-ft (51.2 million $\mathrm{m}^{3}$ ) (table 6 ). This evaporation would be larger than for once-through cooling, because this value includes both the natural and the waste-heat-induced evaporation from the pond.

To compensate for the 41,500 acre-ft (51.2 million $\mathrm{m}^{3}$ ) evaporative loss, a volume of water would need to be withdrawn from the river. If the volume of withdrawn water equaled the evaporation, then the cooling water would accumulate dissolved solids at a rate of 7,850 tons $(7,120 \mathrm{t})$ per year. To avoid this, an amount of water equal to 10 percent of the evaporation rate would need to be constantly removed from the cooling system and returned to the river (this is called blowdown). Consequently, the withdrawal rate would need to be 10 percent greater than the evaporation rate. The annual withdrawals would total 45,700 acre-ft ( 56.3 million $\mathrm{m}^{3}$ ) and the dissolved-solids load of the river would be unchanged due to this water use. The flow of the Yampa River would be diminished by 3 percent, and the dissolved-solids concentration would increase by $4 \mathrm{mg} / \mathrm{L}$ (table 6 ).

Compared with once-through cooling, the effects on the river's biota using a cooling-pond system would be very small. The withdrawal of water would be 2 percent of that needed for once-through cooling, and the blowdown would amount to 0.4 percent of the total annual flow of the Yampa River near Maybell. However, a pond system would affect the terrestrial habitat by converting 4,230 acres $(1,710 \mathrm{ha})$ from land to water. It also would have some effects on local climate, due to the vast amount of heat and vapor transferred to the air over this area. Once-through cooling, by comparison, would spread the effects over a stream reach many miles in length.

A wet-cooling water tower rejects waste heat by bringing the cooling water into contact with moving air as the water falls over baffles, causing it to form small droplets. The water is taken from a collecting basin at the base of the cooling tower, passed through the powerplant condenser, and pumped to the top of the tower. As the water falls through the tower, it moves past a large volume of air driven either by fans or by natural buoyancy. During this period of contact, some of the water evaporates. In addition, the water is cooled by the transfer of heat (conduction). The air leaving the tower generally is saturated and is at a greater temperature than it was when it entered the tower. Because part of the water is evaporated as it passes through the tower and a small amount drifts out of the tower structure, water must constantly be added to the system to keep the volume of water in the system from decreasing. In addition, some water must be added to prevent an excessive increase of dissolved solids in the system (fig. 3C).

In a cooling tower, the fraction of waste heat that is rejected by evaporation is an increasing function of the ambient air temperature and a decreasing function of the relative humidity and altitude. By calculating the rate of evaporation for the range of conditions typical of the Yampa River basin, the annual rate of evaporation would be 40,400 acre-ft (49.8 million $\mathrm{m}^{3}$ ) (table 6 ). This blowdown would equal about 10 percent of the evaporation, so the total rate of annual withdrawal from the river would be 44,400 acre-ft $\left(54.7\right.$ million $\left.\mathrm{m}^{3}\right)$.

Assuming an operating system with no direct discharge of residuals to the river, the blowdown (4,040 acre-ft or 5.0 million $\mathrm{m}^{3}$ per year) could be used for transporting ash from the powerplant boilers for discharge into a system of evaporation ponds. For such a system, there is an unresolved question as to the ultimate fate of the residue in the evaporating ponds. Whether these residuals (predominantly salts and sulfur compounds) can be prevented from leaching back into the nearby ground water or surface waters is unknown. An ongoing study at the Hayden powerplant may provide some site-specific information on the possible long-term effects of this form of disposal (S. R. Ellis, written commun., 1978). 
For a wet-cooling tower system, the dissolvedsolids load in the river would decrease by an estimated 8,400 tons $(7,620 \mathrm{t})$ per year, while the dissolved-solids concentration would remain unchanged at $140 \mathrm{mg} / \mathrm{L}$ (table 6). The land area occupied by the towers is considerably less than that required for cooling ponds (National Academy of Engineering, 1972, p. 131). The wet-cooling towers may increase fog, ice, and precipitation over the immediately surrounding area.

In dry-cooling towers, the cooling water moves through a collection of finned tubes and the system operates on the same principle as an automobile radiator. Like an automobile radiator, the rate of consumption of water is virtually zero, because cooling occurs by conduction only (fig. 3D). Several characteristics of dry cooling relative to wet cooling are discussed by Hirsch, James, and Schefter (1978).

Each cooling-system technology has its own advantages and disadvantages. For example, to avoid withdrawing the vast amounts of water necessary for once-through cooling, ponds that evaporate substantially more water can be used. To prevent the dissolved-solids concentration of the river from increasing when an evaporative system is used, the long-term hazard of permanent impoundment of the salts must be accepted. To achieve the advantages of no water consumption at all, the increased air pollution and waste of coal due to the decreased efficiency of a powerplant with dry cooling must be accepted.

Perhaps a useful comparison of water-use implications for coal-use alternatives is to consider inbasin conversion of an additional 12.5 million tons (11.3 million t) of coal to electricity or synthetic gas products or export of the same amount of coal via a slurry pipeline. Comparisons of withdrawals and consumption of water are made in figure 4 . The inagnitude of water-use requirements in electric-power-generation facilities can be noted. All water exported in a slurry pipepine is a consumptive loss from the standpoint of the basin; however, some of this water can be recovered and used at the delivery end of the pipeline. Nonetheless, basin water losses using a slurrypipeline transport alternative are about one-fifth to one-third as great as the losses for cooling purposes in electric-power generation in the basin (fig. 4B).

The choice of coal use has a profound effect on the amounts and forms of discharged waste residuals that must be assimilated into the environment (Steele, 1978a). Using the set of seven mixed coal-resources development alternatives, the projected residuals given previously in table 5 are aggregated and compared in figure 5. Total residuals discharged increase both as a function of the coal mined and the amount of the coal converted to other energy forms in the basin. These projected discharges include both direct and indirect impacts. As noted in table 4, the indirect effects of population, urban development, and services constitute the dominant part of several residual forms (Bower and Basta, 1973). With increasing in-basin coal use, greater amounts of solid residuals have to be contended with; these residuals dominate the total discharge loadings (table 5; fig. 5). As will be discussed later, chemical constituents from these residuals through decomposition processes may still adversely affect hydrologic conditions adjacent to disposal areas.

In summary, each cooling technology has both advantages and disadvantages (Reynolds, 1980). Some disadvantages must be accepted in order to obtain the advantages of a given technology. For example, evaporation ponds or wet-cooling towers can be used to avoid withdrawing the large amounts of water needed for once-through cooling. However, this lower rate of withdrawals is accompanied by a higher rate of consumptive use and a greater amount of dissolved solids requiring disposal. For any given combination of coal uses there are different water-use and residuals-generation impacts. Among all of the options considered in this study, those involving transport of the coal in raw form have the smallest impacts.

\section{SURFACE-WATER INVESTIGATIONS}

$$
\text { By DANiel P. Bauer }
$$

Three study components composed the surfacewater investigations for the Yampa River basin assessment: (1) an analysis of the waste-load assimilative capacity for a reach of the Yampa River between Steamboat Springs and Hayden, Colo.; (2) an evaluation of several hydraulic characteristics of selected subreaches of the Yampa and the Little Snake Rivers; and (3) a modeling analysis of several proposed reservoirs. Selected results of each of these studies are highlighted. Detailed informa- 

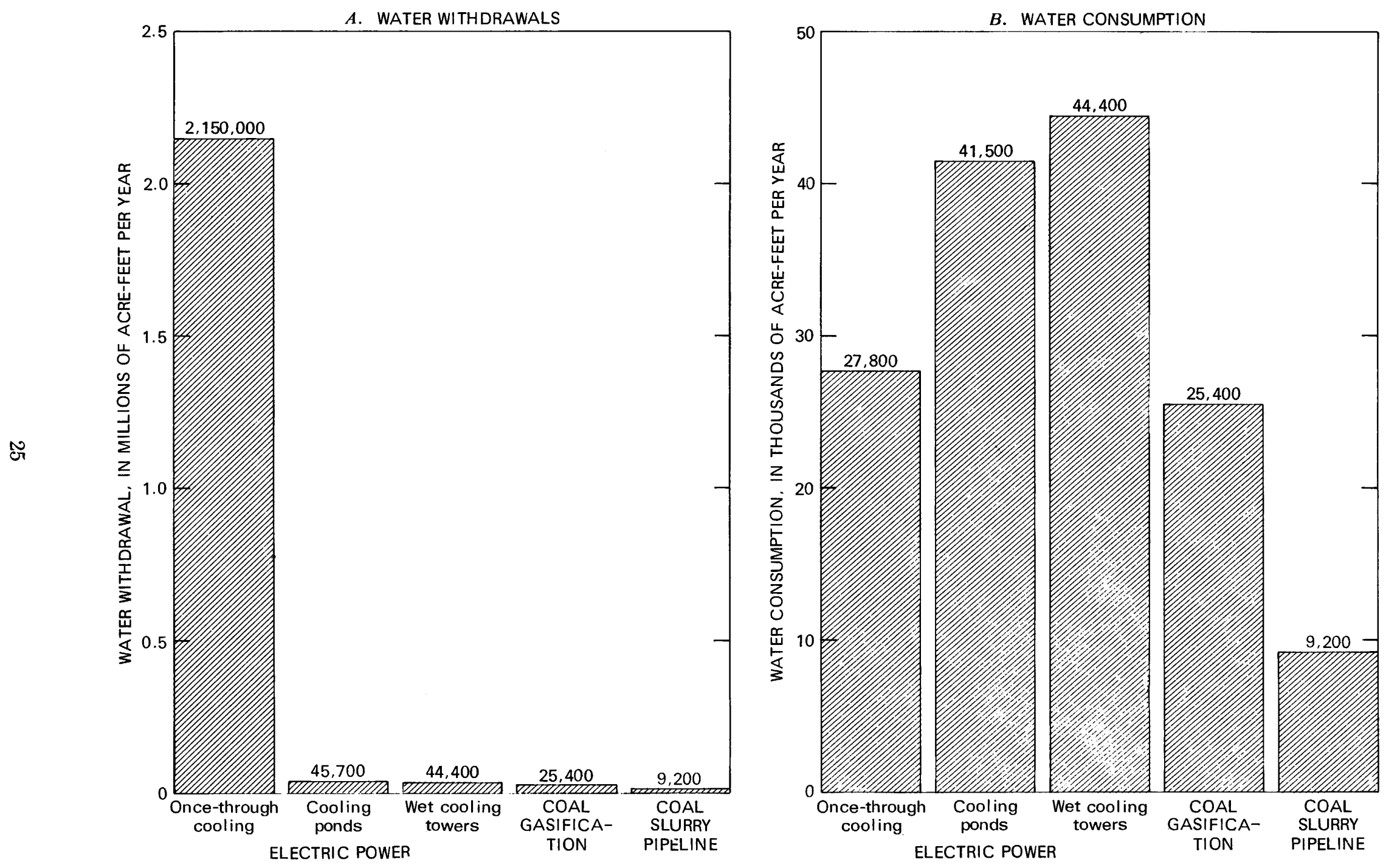

FigURE 4.-Comparison of water use for alternative cooling systems and coal use assuming 12.5 million tons (11.3 million $t$ ) of coal mined per year. (Modified from Hirsch and others, 1978.) 


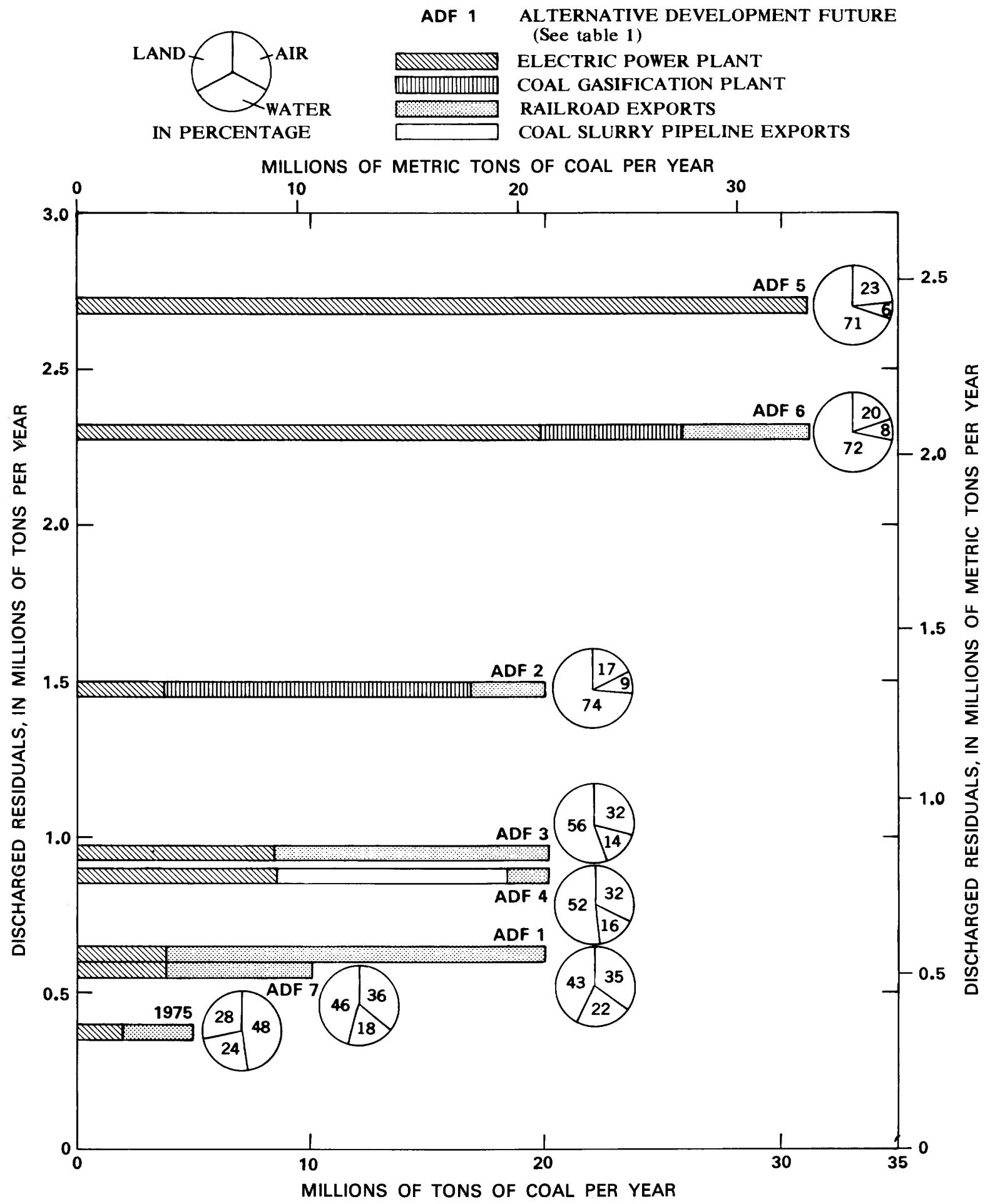

FIGURE 5.-Projections of total residuals resulting from coal-development alternatives, 1990. (J. E. Shefter, written commun., 1977; Steele, 1978b.) 
tion on each study is documented in reports as indicated in the discussion.

The analysis of the waste-load assimilative capacity indicated that concentrations of nonionized ammonia nitrogen in the Yampa River from Steamboat Springs to Hayden (fig. 2) may exceed the State's proposed stream standards of 0.2 $\mathrm{mg} / \mathrm{L}$ on peak-population days (Bauer and others, 1978). The computed concentrations were based on population projections for the year 2010 derived from several planning studies (Gathers and Associates, Inc., 1976; U.S. Environmental Protection Agency, 1977). December and September streamflow conditions and different population projections for 2010 were considered (Bauer and others, 1978).

Several major factors-for example, existing stream-reach classifications for aquatic life, suggested standards for effluent from a proposed regional wastewater-treatment plant, and Steamboat Springs area population projections--were considered in the model simulations. For the model-simulation phase, it was assumed that all water-quality variables considered by the model were only temperature dependent. For example, the simulation for December basically assumed the same biologic and $\mathrm{pH}$ conditions as assumed for September, which introduced some degree of uncertainty into the model-simulation results. Nonionized ammonia concentrations were computed separately, with due consideration given to prevailing conditions of temperature as well as $\mathrm{pH}$.

Concentrations of nonionized ammonia determined from computed ammonia concentrations exceeded the proposed State standard for existing wastewater-treatment-plant effluent when 7-day low flows with a 10 -year recurrence interval $\left(Q^{7} 7,10\right)$ of $28 \mathrm{ft}^{3} / \mathrm{s}\left(0.9 \mathrm{~m}^{3} / \mathrm{s}\right)$ were assumed (fig. 6). Possible augmented flows of $20 \mathrm{ft}^{3} / \mathrm{s}\left(0.6 \mathrm{~m}^{3} / \mathrm{s}\right)$ released from a proposed upstream reservoir such as the Yamcolo Reservoir (fig. 2) would reduce the in-stream effects of wastewater-treatment-plant effluents (fig. 6). The fraction of ammonia nitrogen that exists in nonionized form increases with increasing $\mathrm{pH}$. When $\mathrm{pH}$ exceeds 8.5 , nonionized-ammonia concentrations may become great enough to be toxic to fish (Willingham, 1976).

Stream-reaeration coefficients also were computed for several reaches of the Yampa River between Steamboat Springs and Hayden, Colo.
(Bauer and others, 1979). Reaeration, the physical absorption of oxygen from the atmosphere, is the primary process by which a stream replaces the oxygen consumed in the biodegradation of organic wastes. For the reaeration-coefficient computation procedure, ethylene and propane were used as tracer gases and rhodamine-WT dye was used as dispersion tracer. The basic premise of the reaeration-coefficient computation is that the ratio of the rate coefficient for a tracer gas desorbing from water to the rate coefficient for oxygen being absorbed by the same water is a constant and is independent of mixing and water temperature. Measured reaeration coefficients, adjusted to $20^{\circ} \mathrm{C}$, range from 33.4 to $6.04 \mathrm{~d}^{-1}$ for the stream reaches. These direct measurements were then compared with coefficients computed using several semiempirical and empirical functions (Bauer and others, 1979).

The model used for the waste-load assimilativecapacity analysis similarly could be used in other stream reaches in which steady-state assumptions of streamflow and waste inputs are acceptable. Steady-state assumptions may be acceptable in many situations, particularly when the focus of a study is on critical-flow conditions, usually associated with low-flow periods for a given stream.

A semiempirical reaeration-rate formula by Tsivoglou and Neal (1976) compared the closest to the measured reaeration data for the Yampa River. A technique described by Bennett and Rathbun (1972) was used for the earlier waste-load assimilative-capacity analysis (Bauer and others, 1978). The amount of error difference because of the use of the Bennett and Rathbun (1972) formula is not known. Because of the many available empirical and semiempirical reaeration formulas, completion of reaeration studies prior to making a waste-load assimilative-capacity analysis would result in a more accurate analysis.

As part of a second surface-water investigation, traveltime, unit-concentration, and longitudinaldispersion characteristics were measured for stream reaches on the Yampa and the Little Snake Rivers. Two sets of data were collected for the Yampa River and three sets of data were collected for the Little Snake River. Information on traveltime and unit concentrations provides a convenient means of predicting the timing and peak con- 
DISTANCE FROM MOUTH, IN KILOMETERS

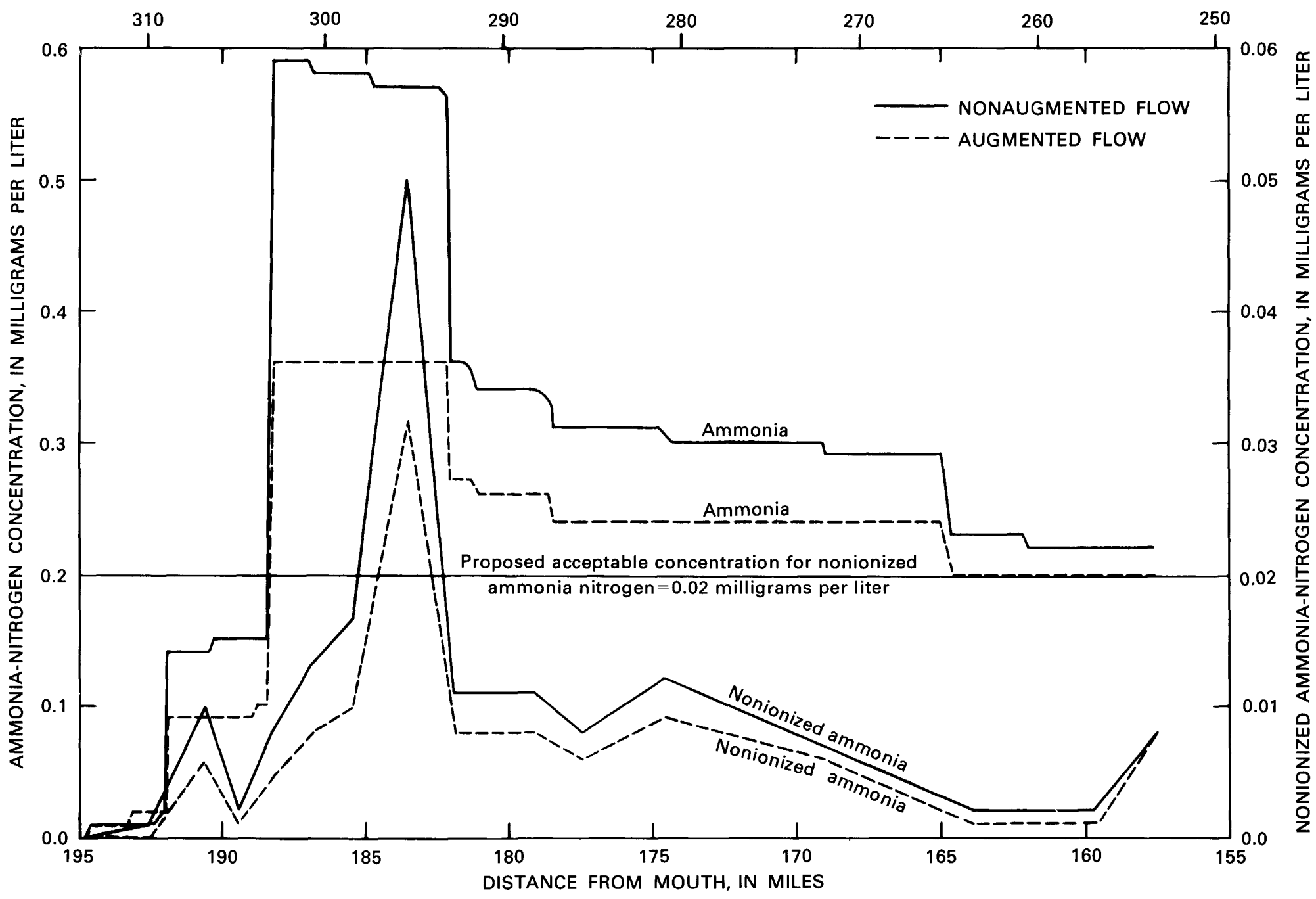

FIGURE 6.-Computed concentrations of ammonia nitrogen for existing wastewater-treatment facilities and 7-day low flows with a 10-year recurrence interval in the Yampa River. (From Bauer and others, 1978; Steele, 1978a.) 
centrations at various downstream locations for a contaminant discharged or spilled upstream.

Traveltime and unit concentrations for a range of stream-discharge conditions were estimated using the measured data and a mathematical model described by McQuivey and Keefer (1976). The simulation of traveltime and unit-concentration data involves initially calibrating the model for the observed data and then simulating results to other flow conditions. Cumulative traveltime and unitconcentration relationships can then be derived for any stream reaches at any assumed discharge (Bauer and others, 1979). Traveltime simulations for the Little Snake River using the model-analysis scheme were compared and agreed within 5 percent of the measured medium-flow data for May 1977. A similar comparison also was made for the unitconcentration data, with agreement within 30 to 40 percent. Traveltime simulations based on linearregression relationships of mean stream velocity or discharge also are given for both streams (Bauer and others, 1979). Longitudinal-dispersion coefficients, computed for the Yampa and the Little Snake Rivers, ranged from 6,050 to $400 \mathrm{ft}^{2} / \mathrm{s}(560$ to $37 \mathrm{~m}^{2} / \mathrm{s}$ ) for the two streams.

As an example of an application of the derived traveltime information, assume that an accidental spill occurred in the Steamboat Springs area in which 1,000 pounds $(453 \mathrm{~kg})$ of a soluble conservative contaminant was spilled into the Yampa River. Assume a stream discharge at Steamboat Springs (fig. 2) of $1,000 \mathrm{ft}^{3} / \mathrm{s}\left(28 \mathrm{~m}^{3} / \mathrm{s}\right)$. One immediate concern might be to determine the arrival time and peak concentration of this contaminant at the Hayden water plant downstream. At this discharge, the traveltime of the leading edge of the conservative contaminant could be expected to arrive at Hayden in approximately 12.5 hours. The estimated peak concentration would be $1,580 \mu \mathrm{g} / \mathrm{L}$ at Hayden, 15.7 hours after the spill (Bauer and others, 1979). Health standards for a particular contaminant would indicate the potential toxic effects of such a concentration and dictate whether or not the water use should be curtailed.

In conclusion, prediction of travel rates and dispersion in streams is important for pollution control and for use as a warning system in case of contaminant spillage upstream from critical wateruse diversion points. The technique described above provides a means of estimating stream- travel rates and unit concentrations for a large range in flow conditions, based on one fieldsampling study. In cases where no traveltime studies can be made, a regional regression relationship may be used (Boning, 1974).

In order to meet projected future demands for water, considerable interest has been expressed and plans proposed for additional development of surface waters of the Yampa River basin. As indicated by Maddock and Matalas (1980), some of the future water demands involve year-round use for cooling systems in coal-conversion facilities. Also, anticipated population growth results in increased household and service-related water demands. Streamflow in the basin presently is regulated by few reservoir impoundments. Thirtyfive major reservoirs with storage capacities larger than 2,000 acre-ft $\left(2.5\right.$ million $\left.\mathrm{m}^{3}\right)$ have been proposed as part of 18 surface-water projects (Steele, 1980). The total potential reservoir capacity is approximately 2.2 million acre- $\mathrm{ft}$ ( 2.7 billion $\mathrm{m}^{3}$ ), which is 41 percent more than the mean annual outflow from the basin. Feasibility and planning reports for several of the proposed reservoirs have been prepared (Oak Creek Power Co., 1976; U.S. Department of the Interior, 1976b). Two projects to export substantial amounts of water for use outside the basin also have been proposed. These include the Vidler Tunnel diversion involving tributaries of the Yampa River and the Hog Park diversion involving tributaries of the Little Snake River (fig. 2).

Within this particular investigation, three modeling efforts were conducted interactively as a demonstration study to evaluate various aspects of proposed reservoir development and the transmountain diversions (D. B. Adams, D. P. Bauer, R. H. Dale, and T. D. Steele, written commun., 1978). A reservoir-system model, HEC-3 (U.S. Army Corps of Engineers, 1968), was used to analyze effects on streamflow of alternative reservoir configurations described below. A riversalinity model (Ribbens, 1975) was used to estimate dissolved-solids concentrations at selected locations in the basin for the different reservoir configurations. A third model, using the streamflow and water-quality information provided in part by the first two models, evaluated inreservoir water temperatures and specificconductance conditions at selected sites for as- 


\begin{tabular}{|c|c|c|c|}
\hline Reservoir & Stream & $\begin{array}{l}\text { Storage capacity } \\
(\text { acre-ft) }\end{array}$ & Configuration \\
\hline Sand stone- & Savery Creek---.-- & 15,500 & ${ }^{1} 2,3,4$ \\
\hline Pot Hook-- & Slater Fork--.-- & 60,000 & $1_{2,3,4}$ \\
\hline Yamcolo--- - - & Bear River-- & 9,000 & 1,2 \\
\hline Bear $^{2}-\cdots--n-n$ & Yampa River------ & 11,610 & 1 \\
\hline Blacktail ${ }^{3}-\ldots$ & Yampa River------ & 229,250 & $2,3,4$ \\
\hline Lower Green ${ }^{3}$ & Green Creek------ & 99,600 & $2,3,4$ \\
\hline Childress ${ }^{3}-\ldots$ & Trout Creek------- & 24,160 & $2,3,4$ \\
\hline Upper Middle $\mathrm{e}^{3}$ & Middle Creek- & 102,200 & $2,3,4$ \\
\hline Lower Middle $\mathrm{e}^{3}$ & Middle Creek----- & 25,150 & $2,3,4$ \\
\hline Jun i per---n & Yampa River------- & $1,079,990$ & $1,2,3$ \\
\hline Cross Mountain---- & Yampa River-..... & 142,000 & $1,2,3$ \\
\hline Hinman Park- & Elk River---n- & 44,040 & 3,4 \\
\hline Grouse Mountain- & Willow Creek------ & 79,260 & 3,4 \\
\hline Pleasant Valley----- & Yampa River-------- & 43,220 & 3,4 \\
\hline Dunckley-- & Fish Creek-- - - & 57,090 & $1_{3,4}$ \\
\hline California Park------ & Elkhead Creek---- & 36,540 & 3,4 \\
\hline Craig-- & Yampa River------- & 44,490 & 3,4 \\
\hline
\end{tabular}

lomitted from river-salinity analysis of configuration 4 .

${ }^{2}$ Competes for Blacktail Reservoir site.

${ }^{3}$ Oak Creek Water \& Power Project.

sumed inflow conditions and outflows (Adams, 1975).

The various proposed reservoirs considered in the study analyses are listed in table 7 and are located on the basin map (fig. 2). These represent the greater part of the total storage volume of known proposed reservoirs in the basin. The four alternative configurations of reservoir development 
used to demonstrate the application of the named models were as follows:

1. Upper-lower configuration-Juniper-Cross Mountain and Yamcolo-Bear Reservoirs.

2. Moderate-development configuration-alternative 1 plus Sandstone-Pothook and Oak Creek Power \& Water Project Reservoirs.

3. High-level development configuration-alternative 2 plus six additional reservoirs as indicated in table 7 .

4. Upper mainstem and tributary configuration-alternative 3 without Juniper-Cross Mountain Reservoirs.

Each configuration was also analyzed with and without the transmountain diversions described earlier. Data requirements for each of the modeling studies and details of the study approaches are described by D. B. Adams, D. P. Bauer, R. H. Dale, and T. D. Steele (written commun., 1978).

To demonstrate results from the river-salinity modeling analysis, estimated regulated versus unregulated mean monthly streamflows and dissolved-solids concentrations of the Yampa River at Deerlodge Park, Colo. (fig. 2), are shown in figure 7 for assumed reservoir configurations 1,2 , and 4 (table 7). These model analyses are based on historical flows and dissolved-solids concentrations, the latter being extrapolated by regression analysis from available records of specific conductance (Wentz and Steele, 1980).

The reservoir-system model analysis, which considered four reservoir configurations and two transmountain diversions, indicated that periods of water shortage would occur for both storage and export. For example, shortages for the Vidler Tunnel diversion would occur from 42 to 77 percent of the time, while shortages for the Hog Park diversion would occur 20 percent of the time. The greatest amounts of shortages for in-basin uses occurred for Juniper Reservoir irrigation diversions and Blacktail Reservoir releases for powerplant cooling (D. B. Adams, D. P. Bauer, R. H. Dale, and T. D. Steele, written commun., 1978).

Model results for reservoir configuration 2 (fig. 7B) are quite similar to those discussed above for configuration 1 . The dominating effect of Juniper and Cross Mountain Reservoirs on the downstream part of the mainstem Yampa River (fig. 2) is apparent.

In reservoir configuration 4 , five additional reservoirs are assumed to be constructed, however, without Juniper and Cross Mountain Reservoirs.
The principal assumed water uses from those reservoirs are additional irrigation and cooling water for coal-conversion facilities. Downstream on the Yampa River at Deerlodge Park, streamflow decreases would be more apparent during snowmelt runoff in the spring (April through June) (fig. 7C). Seasonal variations in dissolved-solids concentrations would have some differences but would be virtually unchanged on an annual time-weighted basis.

Prior to extensive reservoir development, more specific reservoir-modeling analyses than those demonstrated in a more detailed technical report (D. B. Adams, D. P. Bauer, R. H. Dale, and T. D. Steele, written commun., 1978) need to be conducted to aid in evaluating interactive and downstream effects of such development. Additional consideration of the ramifications relative to basin-compact requirements and infringements of senior water rights need to be incorporated into such a specific analysis. The reservoir-modeling study (D. B. Adams, D. P. Bauer, R. H. Dale, and T. D. Steele, written commun., 1978) served only to demonstrate the application of modeling techniques in evaluating the impacts of reservoir development. The reservoir-system and dissolvedsolids models used in this analysis were quite simplistic and were relatively easy to apply; whereas, the third model used to evaluate inreservoir conditions was more complex in structure, in operation, and in detail of required data. The three models selected for the reservoir-modeling study were based principally on the data and resources available for the effort. Several choices are presented to the reservoir modeler who is required to provide results of alternative proposed plans to water-resources managers. The modeler first needs to decide the desired accuracy to fulfill the specified objectives of the effort and then should evaluate thoroughly the available existing data. From such an evaluation, the model selection can be made realistically for a given study effort.

\section{STREAM QUALITY}

$$
\text { By Dennis A. Wentz }
$$

Water is vital to those persons living in the Yampa River basin. Future economic development, including coal mining, conversion, and transport, is in part dependent upon existing and future water-quality conditions. 

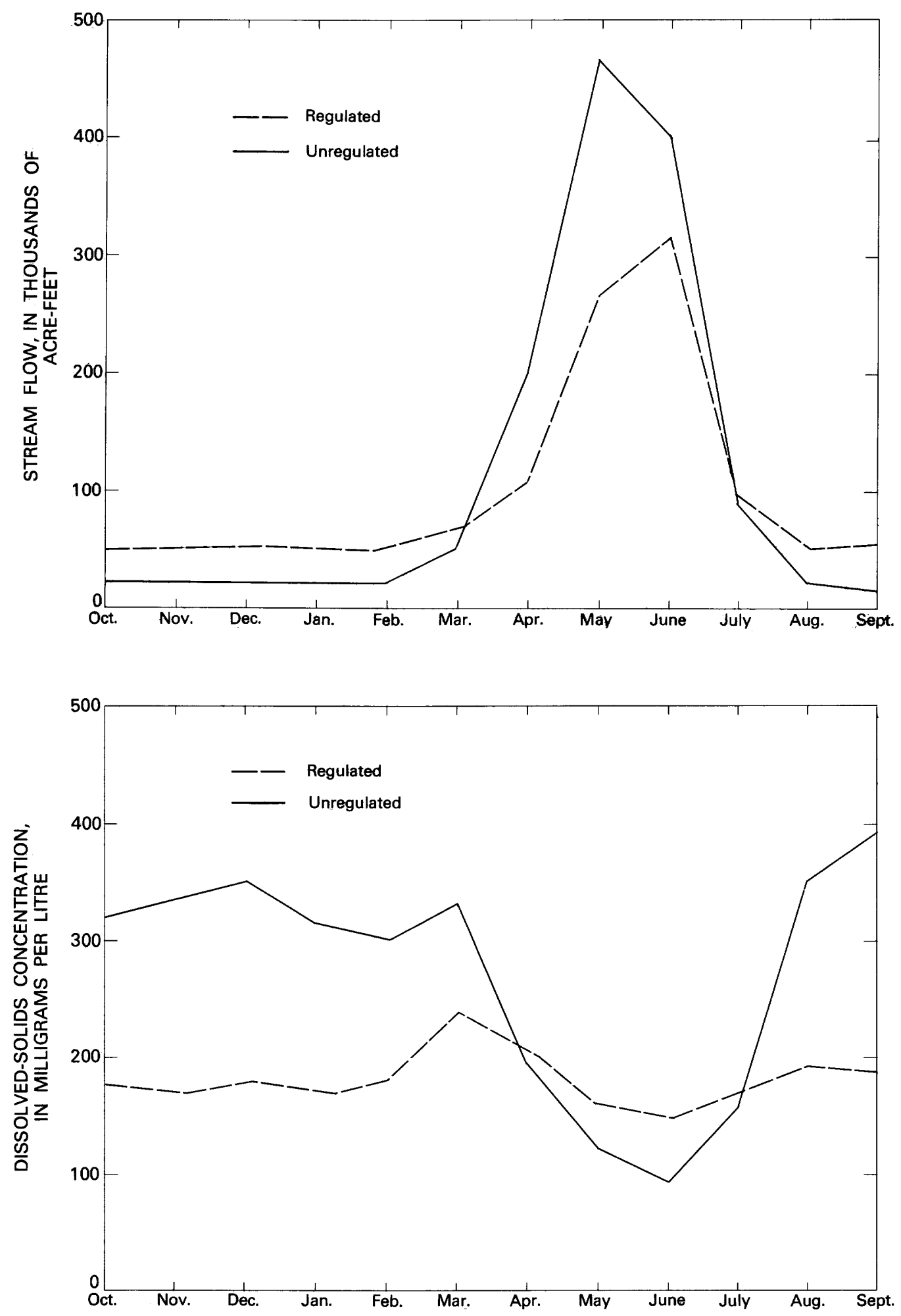

A. Reservoir configuration 1

FIGURE 7.-Comparison of mean monthly variations in regulated and unregulated streamflow and dissolved-solids concentrations, Yampa River at Deerlodge Park, Colo., 1951-69 water years (R. 

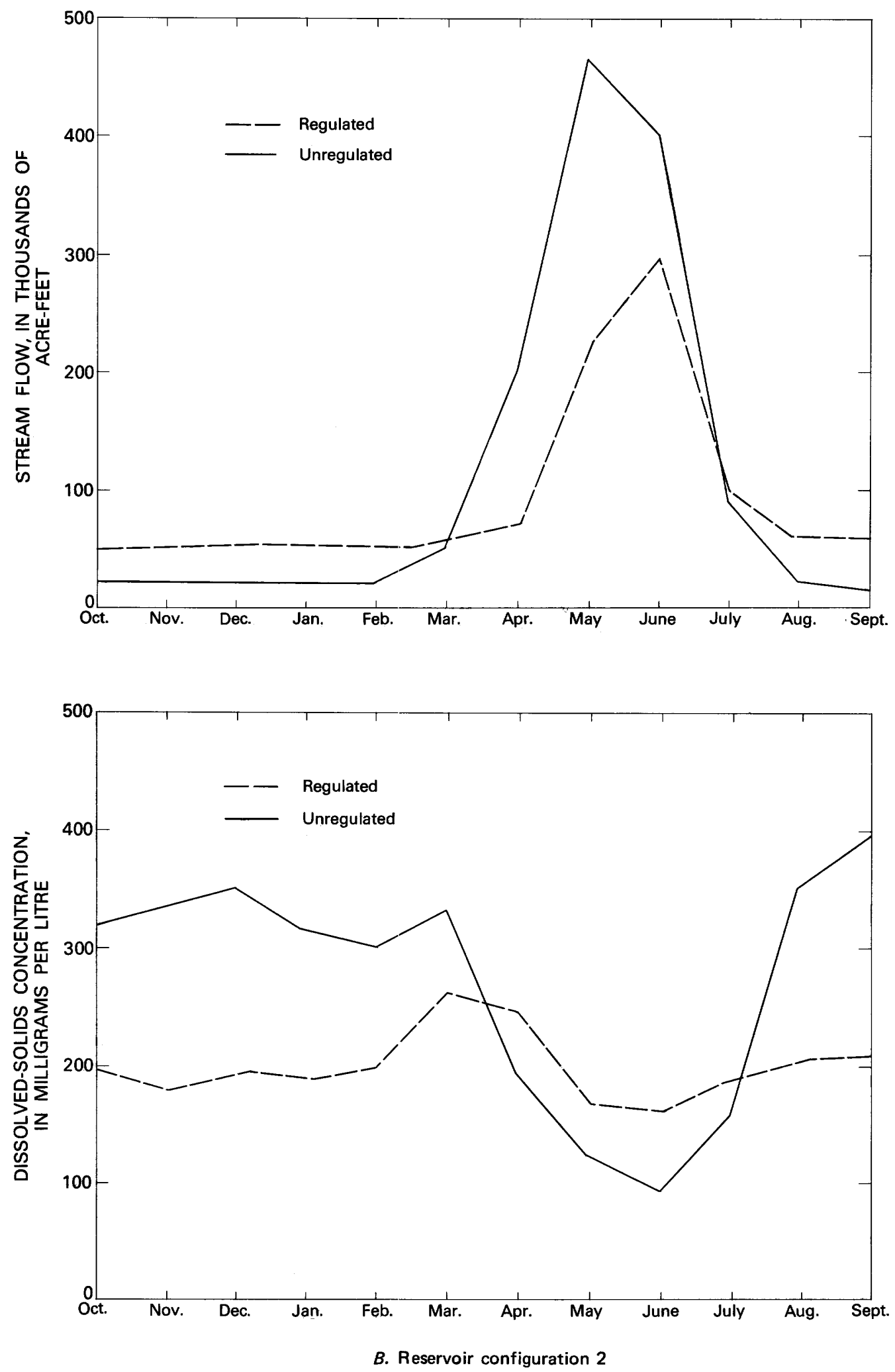

H. Dale, written commun., 1978): $(A)$ reservoir configuration $1 ;(B)$ reservoir configuration $2 ;(C)$ reservoir configuration 4 . 

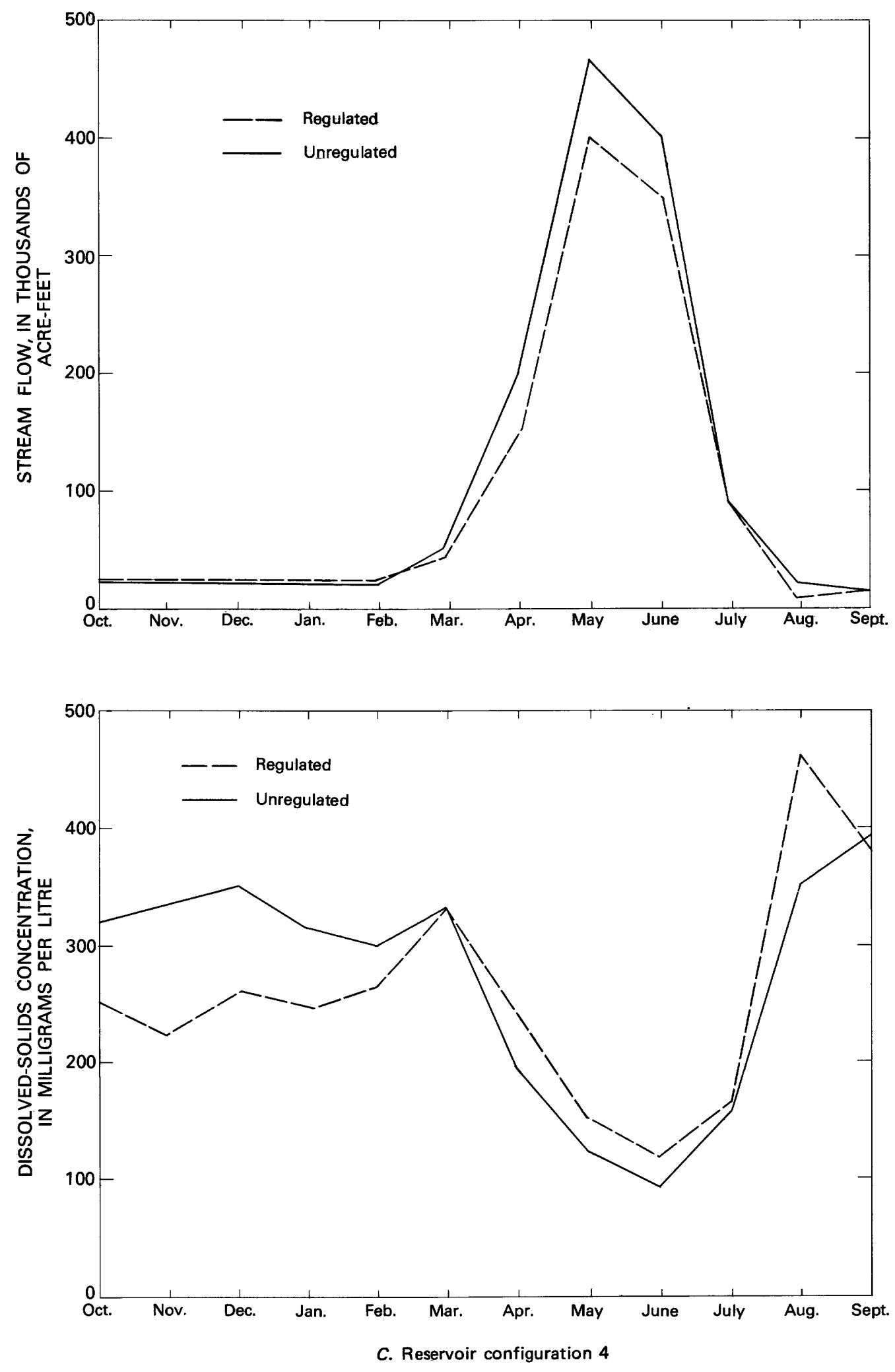

FigURE 7.-Continued. 
An areal depiction of predevelopment streamquality conditions in the Yampa River basin provides a useful basis upon which to evaluate the incremental effects of coal-resource and associated economic development (Wentz and Steele, 1978). Other than the statistical techniques described in this section, modeling techniques to specifically predict stream-quality changes resulting from coalresource and associated economic development and associated water uses are still being developed or are nonexistent. Hence, the following description is a qualitative analysis of predevelopment streamquality conditions.

The assessment of predevelopment stream quality consisted of two phases. During the first phase, information available from past (Iorns and others, 1964) and ongoing data-collection programs were evaluated. During the second phase, basinwide reconnaissance and quarterly-sampling programs to complement the prior data were designed and implemented.

Detailed evaluations of historic data on stream temperature and major inorganic constituents are given by Wentz and Steele (1980). The results of the basinwide reconnaissance were based on data collected at 85 stream sites throughout the Yampa River basin during August-September 1975 (fig. 8). Site descriptions, type of data collected at each site, and interpretation of these data are discussed in detail by Wentz and Steele (1980). The data from the basinwide reconnaissance have been published by Giles and Brogden (1978).

Based on the results of the basinwide reconnaissance, 42 quarterly sampling sites (fig. 8) were chosen to determine the seasonal changes in stream quality and variations in stream discharge. Descriptions of these sites are presented by Wentz and Steele (1980, table 1). Sampling was conducted during December 1975, and during March, June, and August-September 1976. The resultant data have been published by the U.S. Geological Survey (1978).

The smallest trace-element concentrations were determined in samples collected at low flows during August-September 1976. The mean concentrations and the frequency distributions, for most trace elements (both dissolved and total forms), were similar for both sampling periods during August-September 1975 and 1976. The only exceptions were dissolved vanadium, total zinc, and, possibly, dissolved cobalt (Wentz and Steele, 1980).
The frequency distributions of some trace elements (for example, total mercury) did not change throughout the period of study. However, frequency distributions for many dissolved and total trace elements indicated that most maximum concentrations occurred during March 1976, as shown by the frequency distributions for total manganese (fig. 9). Reasons for the March maximums in both dissolved and total trace-element concentrations are not apparent. The large total trace-element concentrations during March 1976 apparently resulted primarily from large concentrations of suspended forms, and these may have been associated with large suspended-sediment concentrations noted during the sampling. Also, the lowest $\mathrm{pH}$ values were measured during March 1976 (Wentz and Steele, 1980) and may have contributed to the greater solubility of some trace elements at this time of year, and, thus, to the larger concentrations of dissolved forms.

During the quarterly sampling program, iron and manganese again accounted for the majority of instances (90 percent) where public water-supply standards for dissolved or total concentrations (Colorado Department of Health, 1977) were exceeded, just as they did during the basinwide reconnaissance. Cadmium was the trace element most commonly exceeding aquatic-life standards (32 percent of the total number of occurrences where aquatic-life standards were exceeded).

Except for mercury, and possibly chromium, the smallest trace-element concentration in streambottom sediments were determined in samples collected during August-September 1976. Concentrations of some trace elements (for example, arsenic-fig. 10) decreased gradually from 1975 to 1976. Others, such as copper, decreased most after March 1976. Often, as in the latter instance, the seasonal pattern may have been somewhat obscured by the fact that a different laboratory procedure was used for determining concentrations in samples collected during June 1976. Small traceelement concentrations in the surficial bottom sediments during August-September 1976 may have resulted from relatively minor runoff in the basin during the 1976 water year. Sediments deposited in the stream channels during the 1976 water year probably contained smaller traceelement concentrations than were contained in the previously deposited sediments. 


\section{EXPLANATION}

$\nabla^{3}$ RECONNAISSANCE SITE

$\nabla^{71 A}$ QUARTERLY SAMPLING SITE

$\nabla^{1}$ ONGOING (1979) U.S. GEO-

LOGICAL SURVEY

SAMPLING SITE NOT

DIRECTLY ASSOCIATED

WITH THE YAMPA RIVER

BASIN ASSESSMENT

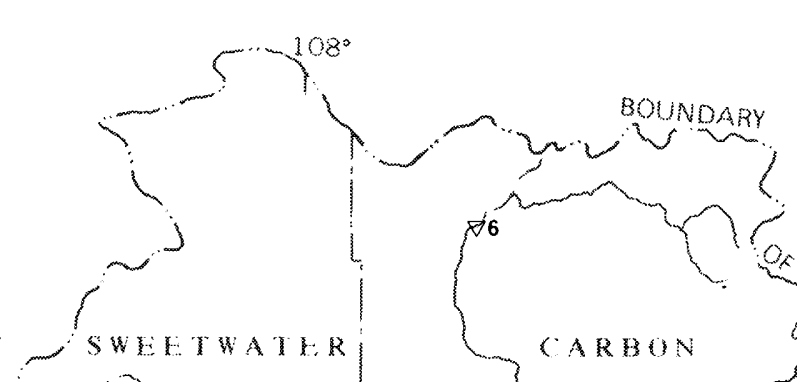

3

SWELTWATLR

$C<\mathrm{RBON}$

YLITTLE SNAKE
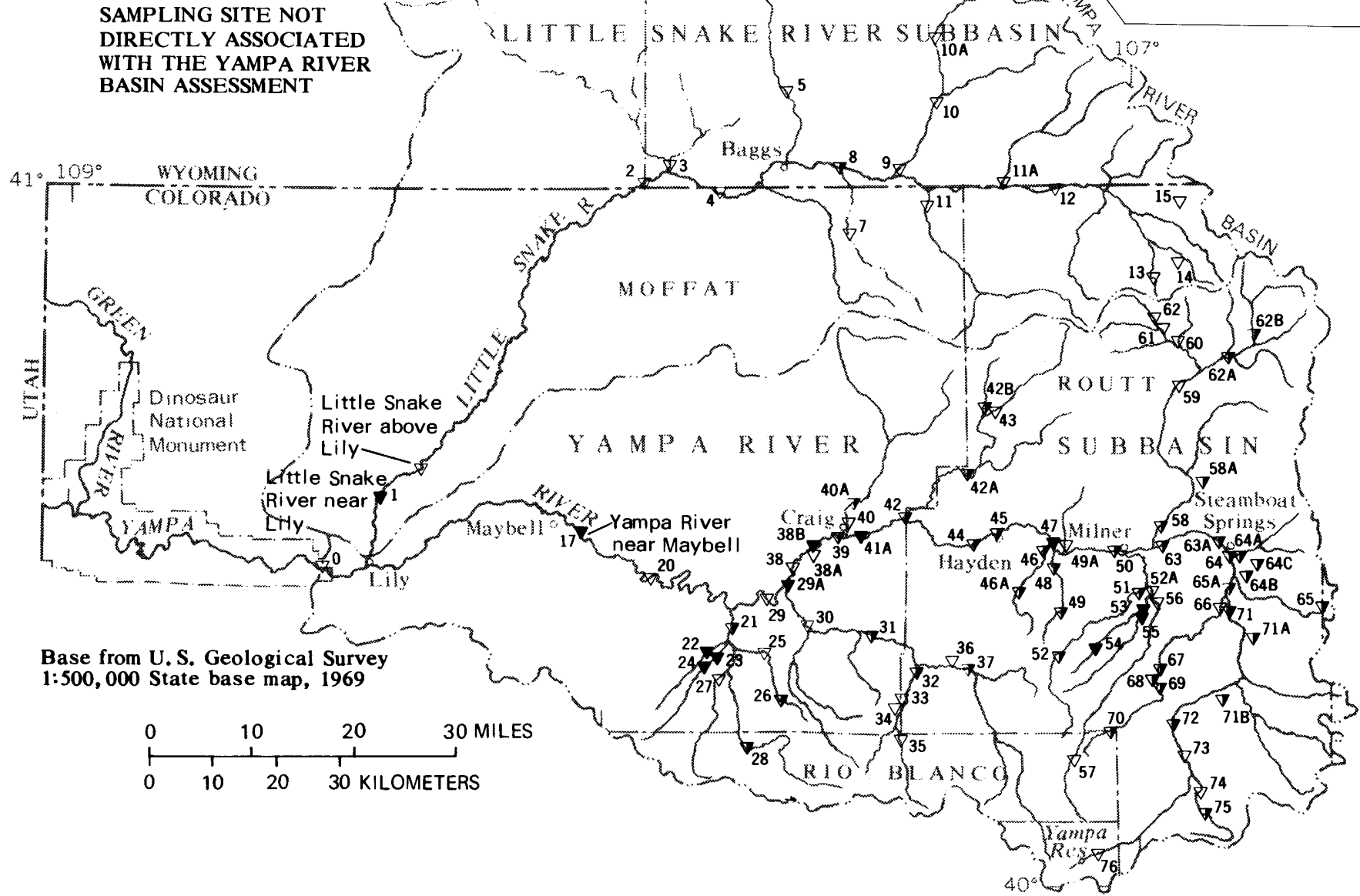

FIGURE 8.-Location of sites where streamflow was sampled during the basinwide reconnaissance, August-September 1975, and during the quarterly sampling program, December 1975 through August-September 1976. (From Wentz and Steele, 1980.) 

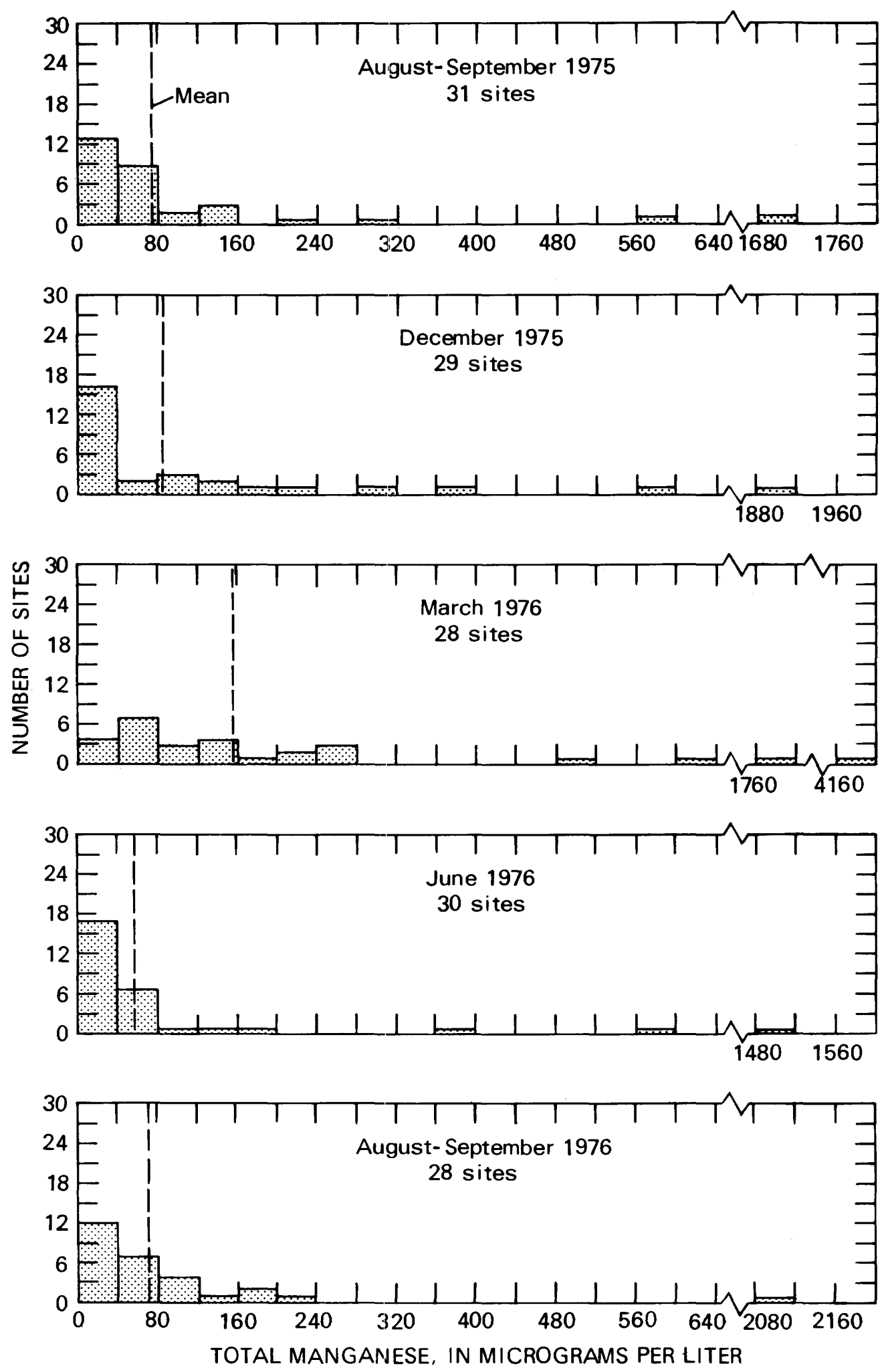

FIGURE 9.-Frequency distributions of total manganese in streamflow, August-September 1975 through August-September 1976. (From Wentz and Steele, 1980.) 

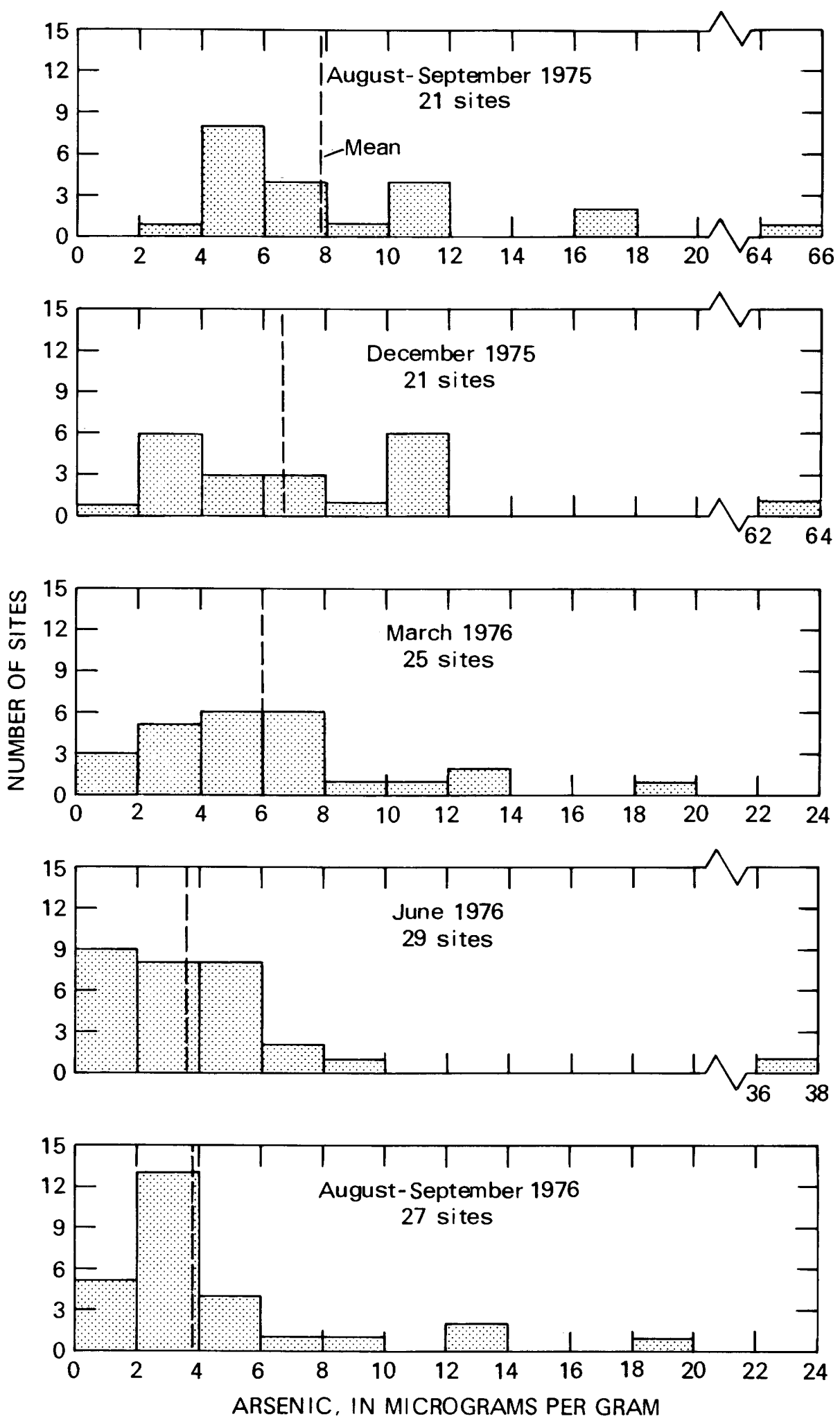

FIgURE 10.-Frequency distributions of arsenic in stream-bottom sediments, August-September 1975 through August-September 1976. (From Wentz and Steele, 1980.) 
The frequency distributions for $\mathrm{pH}$ did not vary greatly throughout the study period. The median $\mathrm{pH}$, however, had a cyclic trend, decreasing from a maximum of 8.4 during August-September 1975 to a minimum of 7.7 during March 1976, and increasing to a maximum of 8.4 during August-September 1976 (Wentz and Steele, 1980). The $\mathrm{pH}$ values during March 1976 may have been due to a combination of relatively cold water temperatures, which increased the solubility of carbon dioxide, and limited buffering capacity, which allowed the hydrogen ion produced by the dissolved carbon dioxide to remain in solution rather than be used to form bicarbonates.

During the quarterly sampling program, only two $\mathrm{pH}$ values exceeded the upper limit of 9.0 for public water supply, and no values were less than the lower limit of 5.0 (Colorado Department of Health, 1977). The same two values exceeded the upper limit of 9.0 for aquatic life; whereas, 13 values were less than the lower limit of 6.5 (Colorado Department of Health, 1977).

The frequency distributions of nutrient concentrations had the same seasonal patterns as dissolved and total trace elements. Large nitrogen (all forms) and total-phosphorus concentrations during March 1976 probably were contributed primarily by runoff from areas grazed by cattle. Organic carbon and dissolved phosphorus did not change seasonally. Apparently the runoff sources contributed relatively little organic carbon; whereas, dissolved phosphorus is readily absorbed and would be expected to be retained in the soil zone.

The upper temperature limit to protect coldwater biota is $20^{\circ} \mathrm{C}$ (Colorado Department of Health, 1977). During the quarterly sampling program from December 1975 through AugustSeptember 1976, 7 of 163 temperature measurements ( 4 percent) exceeded the $20^{\circ} \mathrm{C}$ limit. Three temperatures exceeded $20^{\circ} \mathrm{C}$ were measured during June 1976, and four were measured during August-September 1976. No recorded temperature was greater than the recommended upper limit of $30^{\circ} \mathrm{C}$ for warm-water biota (Colorado Department of Health, 1977). All temperatures greater than $20^{\circ} \mathrm{C}$ appear to have been due to natural causes. Techniques for estimating annual seasonal variations of stream temperature on a regional basis are described by Wentz and Steele (1980) and by Lowham (1978).

The pattern of seasonal changes in the frequency distributions of dissolved oxygen in streams was virtually the same as the pattern of seasonal changes in the frequency distributions of water temperature. This indicated that the dissolvedoxygen concentration was controlled, to a large extent, by the solubility of the gas, which is greater at colder temperatures, and also by reaeration (Bauer, Steele, and others, 1978; Bauer, Rathbun, and others, 1979). Photosynthesis tended to increase dissolved-oxygen concentrations during the late summer months, at 71 percent of the dissolved-oxygen concentrations measured during August-September 1975 and 68 percent measured during August-September 1976 were greater than 100 -percent saturation.

Sites where streamflow quality was degraded during the quarterly sampling program were determined by analyzing the various frequency distributions for dissolved and total trace elements and nutrients and for trace elements in stream-bottom sediments and statistically separating the outliers-indicating degraded conditions-from the background distributions representative of ambient conditions. The results indicated that sites 21, 28, 31, 39, 49, 62A, and 75 (fig. 8) had one outlier each during December 1975 through August-September 1976 and sites 26, 46, and 68 (fig. 8) had more than one outlier each during the same time period. The outlier analysis technique and specific-site conditions are described in detail by Wentz and Steele (1980).

The results of the quarterly sampling program corroborated the results of the basinwide reconnaissance; however, the quarterly sampling program additionally indicated areas of concern for the future. Careful consideration needs to be given to alternative water-and land-use practices in the watersheds upstream from those sites with outliers. The three sites determined to have had more than one outlier each are the same three sites for which basinwide-reconnaissance data indicated upstream water-quality degradation.

Based on the analysis of data collected during the basinwide reconnaissance and during the quarterly sampling program, seasonal variations of maximum likely ambient concentrations of selected chemical constituents were determined. Application of the procedure in this context was first used by Wentz (1974) for detecting impacts of metal mining on Colorado streams. The maximum likely ambient concentration for a given constituent is defined herein as the mean plus twice the standard deviation $(\bar{x}+2 s)$ for data obtained at 
TABLE 8.-Seasonal maximum likely ambient concentrations of chemical constituents in streamflow, August-September 1975 through August-September 1976

[Modified from Wentz and Steele $(1980) . \mathrm{mg} / \mathrm{L}=$ milligram per liter; $\mu \mathrm{g} / \mathrm{L}=$ microgram per liter; $\mu \mathrm{g} / \mathrm{g}=$ microgram per gram]

\begin{tabular}{|c|c|c|c|c|c|}
\hline \multirow[b]{2}{*}{ Constituent } & \multicolumn{5}{|c|}{ Concentration $^{1}(\bar{x}+2 s)$} \\
\hline & $\begin{array}{c}\text { August- } \\
\text { September } \\
1975\end{array}$ & $\begin{array}{l}\text { December } \\
1975\end{array}$ & $\begin{array}{r}\text { March } \\
1976\end{array}$ & $\begin{array}{l}\text { June } \\
1976\end{array}$ & $\begin{array}{c}\text { August- } \\
\text { September } \\
1976\end{array}$ \\
\hline $\begin{array}{l}\text { Specific conductance, micromhos per centimeter } \\
\text { at } 25^{\circ} \mathrm{C} \text {. }\end{array}$ & 1,700 & 1,200 & 2,100 & 970 & 1,300 \\
\hline Dissolved organic carbon, $\mathrm{mg} / \mathrm{L}-$ & 21 & 21 & 19 & 20 & 14 \\
\hline Dissolved plus suspended organic carbon, $\mathrm{mg} / \mathrm{L}--$ & 22 & 24 & 26 & ------- & 14 \\
\hline Dissolved Kjeldahl nitrogen, $\mathrm{mg} / \mathrm{L}$ as $\mathrm{N}-$ & .49 & 1.0 & 1.4 & .63 & .69 \\
\hline Total $\mathrm{kjeldahl} \mathrm{nitrogen,} \mathrm{mg} / \mathrm{L}$ as $\mathrm{N}-\cdots-$ & .69 & 1.2 & 2.0 & .80 & .98 \\
\hline Dissolved nitrite plus nitrate, $\mathrm{mg} / \mathrm{L}$ as $\mathrm{N}-----$ & .21 & 1.2 & 6.0 & .095 & .29 \\
\hline Total nitrite plus nitrate, $\mathrm{mg} / \mathrm{L}$ as $\mathrm{N}-$ & .21 & 1.2 & 5.9 & .099 & .31 \\
\hline Dissolved phosphorus, $\mathrm{mg} / \mathrm{L}$ as $\mathrm{P}$ & .067 & .15 & .16 & .096 & .25 \\
\hline Total phosphorus, $\mathrm{mg} / \mathrm{L}$ as $\mathrm{P}-$ & .13 & .18 & .45 & .20 & .32 \\
\hline Dissolved antimony, $\mu \mathrm{g} / \mathrm{L--}$ & ------- & 2.4 & .0 & 1.8 & .44 \\
\hline Total antimony, $\mu \mathrm{g} / \mathrm{L}-\mathrm{-}-\mathrm{-}-\mathrm{-}-\mathrm{-}$ & $-\cdots-\cdots$ & 2.4 & 2.9 & .87 & .0 \\
\hline Dissolved arsenic, $\mu \mathrm{g} / \mathrm{L}$ & $-\cdots-n$ & 1.2 & 2.7 & 1.6 & 2.1 \\
\hline Total arsenic, $\mu \mathrm{g} / \mathrm{L}-\ldots-$ & ------- & 1.4 & 10 & 2.8 & 2.7 \\
\hline Dissolved cadmium, $\mu \mathrm{g} / \mathrm{L}-\mathrm{-}$ & .0 & 1.7 & 4.9 & 1.4 & 1.6 \\
\hline Total cadmium, $\mu \mathrm{g} / \mathrm{L}-\cdots$ & $\left({ }^{2}\right)$ & $\left({ }^{2}\right)$ & $\left({ }^{3}\right)$ & $\left({ }^{4}\right)$ & $\left({ }^{2}\right)$ \\
\hline Dissolved cobalt, $\mu \mathrm{g} / \mathrm{L}$ & .56 & 1.9 & 1.7 & 1.3 & 2.1 \\
\hline Total cobalt, $\mu \mathrm{g} / \mathrm{L}---\cdot-$ & 62 & $\left({ }^{5}\right)$ & $\left({ }^{6}\right)$ & $(6)$ & $\left({ }^{6}\right)$ \\
\hline Dissolved copper, $\mu \mathrm{g} / \mathrm{L}-------$ & 3.0 & 9.7 & 4.1 & 4.6 & 2.2 \\
\hline Total copper, $\mu \mathrm{g} / \mathrm{L}-\ldots$ & 18 & $\left({ }^{7}\right)$ & $\left({ }^{7}\right)$ & $(7)$ & $(7)$ \\
\hline Dissolved iron, $\mu \mathrm{g} / \mathrm{L}-\cdots-$ & 160 & 220 & 210 & 170 & 150 \\
\hline Total iron, $\mu \mathrm{g} / \mathrm{L}-\ldots$ & 1,900 & 1,400 & 12,000 & 2,900 & 1,900 \\
\hline Dissolved lead, $\mu \mathrm{g} / \mathrm{L}$ & 1.4 & 6.4 & 15 & 5.1 & 5.5 \\
\hline Total lead, $\mu g / L-\ldots$ & $\left({ }^{8}\right)$ & $\left({ }^{8}\right)$ & $\left({ }^{9}\right)$ & $\left({ }^{8}\right)$ & $\left({ }^{8}\right)$ \\
\hline Dissolved manganese, $\mu \mathrm{g} / \mathrm{L}-\cdots$ & 220 & 320 & 200 & 150 & 130 \\
\hline Total manganese, $\mu \mathrm{g} / \mathrm{L}-\ldots$ & 310 & 350 & 460 & 220 & 180 \\
\hline Dissolved mercury, $\mu \mathrm{g} / \mathrm{L}-\cdots$ & .067 & .062 & .11 & .16 & .00 \\
\hline Total mercury, $\mu \mathrm{g} / \mathrm{L}---$ & .10 & .11 & .046 & .22 & .31 \\
\hline
\end{tabular}


TABLE 8.-Seasonal maximum likely ambient concentrations of chemical constituents in streamflow, August-September 1975 through August-September 1976-Continued

\begin{tabular}{|c|c|c|c|c|c|}
\hline \multirow[b]{2}{*}{ Constituent } & \multicolumn{5}{|c|}{ Concentration $(\bar{x}+2 s)$} \\
\hline & $\begin{array}{c}\text { August- } \\
\text { September } \\
1975\end{array}$ & $\begin{array}{c}\text { December } \\
1975\end{array}$ & $\begin{array}{r}\text { March } \\
1976\end{array}$ & $\begin{array}{l}\text { June } \\
1976\end{array}$ & $\begin{array}{c}\text { August- } \\
\text { September } \\
1976\end{array}$ \\
\hline Dissolved nickel, $\mu \mathrm{g} / \mathrm{L}$ & 4.4 & 4.3 & 3.3 & 4.2 & 2.6 \\
\hline Total nickel, $\mu \mathrm{g} / \mathrm{L}$ & 50 & $\left({ }^{6}\right)$ & $\left({ }^{7}\right)$ & $\left({ }^{6}\right)$ & $\left({ }^{6}\right)$ \\
\hline Dissolved selenium, $\mu \mathrm{g} / \mathrm{L}$ & 2.6 & 1.5 & 15 & 0.0 & 2.1 \\
\hline Total selenium, $\mu \mathrm{g} / \mathrm{L}-\mathrm{c}$ & 3.0 & 2.4 & 19 & .84 & 2.1 \\
\hline Dissolved vanadium, $\mu \mathrm{g} / \mathrm{L}-\ldots$ & 2.7 & 1.0 & 1.9 & 6.0 & 7.0 \\
\hline Dissolved zinc, $\mu \mathrm{g} / \mathrm{L}$ & 14 & 18 & 18 & 26 & 10 \\
\hline Total zinc, $\mu \mathrm{g} / \mathrm{L}$ & 33 & 130 & 69 & 35 & 16 \\
\hline Bottom antimony, $\mu \mathrm{g} / \mathrm{g}$ & 7.0 & 3.1 & 3.8 & 2.2 & .0 \\
\hline Bottom arsenic, $\mu \mathrm{g} / \mathrm{g}-$ & 13 & 14 & 9.3 & 7.7 & 11 \\
\hline Bottom chromium, $\mu \mathrm{g} / \mathrm{g}$ & 50 & 5.4 & 16 & $\left({ }^{7}\right)$ & 12 \\
\hline Bottom copper, $\mu \mathrm{g} / \mathrm{g}-$ & 19 & 22 & 22 & $\left({ }^{7}\right)$ & 13 \\
\hline Bottom iron, $\mu \mathrm{g} / \mathrm{g}$ & 15,000 & 56,000 & 22,000 & 21,000 & 9,900 \\
\hline Bottom lead, $\mu \mathrm{g} / \mathrm{g}-$ & 270 & 29 & 20 & $\left({ }^{7}\right)$ & 29 \\
\hline Bottom mercury, $\mu \mathrm{g} / \mathrm{g}-$ & .072 & .076 & .49 & .26 & .24 \\
\hline Bottom nickel, $\mu \mathrm{g} / \mathrm{g}-$ & 17 & 28 & 45 & $\left({ }^{7}\right)$ & 22 \\
\hline Bottom selenium, $\mu \mathrm{g} / \mathrm{g}---$ & --.---- & .0 & ------ & ---- & - \\
\hline Bottom silver, $\mu \mathrm{g} / \mathrm{g}---$ & $\ldots$ & 4.2 & -- & --- & \\
\hline
\end{tabular}

${ }^{1}$ In a few instances, the dissolved concentration is greater than the total concentration for the same constituent during the same sampling period. This happens because the value of $s$ for the dissolved constituent is greater than the value of $s$ for the total constituent.

${ }^{2} \mathrm{All}$ values were less than $10 \mathrm{\mu g} / \mathrm{L}$.

${ }^{3} \mathrm{All}$ but three values were less than $10 \mu \mathrm{g} / \mathrm{L}$.

${ }^{4} \mathrm{All}$ but one value were less than $20 \mu \mathrm{g} / \mathrm{L}$.

${ }^{5} \mathrm{All}$ but one value were less than $50 \mathrm{\mu g} / \mathrm{L}$.

${ }^{6} \mathrm{All}$ values were less than $50 \mathrm{\mu g} / \mathrm{L}$.

${ }^{7}$ The parameters $\bar{x}$ and $s$ could not be calculated because too many data values were reported as

less than a given number.

${ }^{8} \mathrm{All}$ values were less than $100 \mu \mathrm{g} / \mathrm{L}$.

${ }^{9} \mathrm{All}$ but two values were less than $100 \mu \mathrm{g} / \mathrm{L}$. 
sites determined from the outlier analysis to be unaffected by upstream water-quality degradation. This includes all sites sampled during the basinwide reconnaissance except $21,26,46,54$, and 68 , and all sites sampled during the quarterly sampling program except 26,46 , and 68 (Wentz and Steele, 1980). A summary of maximum likely ambient concentrations for selected constituents is given in table 8 .

As future coal-resource and associated economic development occur, data from subsequent streamquality sampling programs can be compared to the results already determined. Determination of longterm trends would require establishment of programs in which samples would be collected and analyzed in a consistent manner during several years. Program objectives need to be clearly defined with respect to sampling locations, sampling procedures, frequency of sampling, sample preservation, analytical techniques and accuracy, and constituents to be determined (Sanders and others, 1980).

Stream-quality reconnaissance in other areas where energy-resource development is increasing or planned would provide a basis on which to determine water-quality changes due to such development. Including a variety of water-quality constituents, in addition to those for which applicable stream-quality standards exist, would provide a better basis on which to evaluate geochemical changes that might adversely affect fish and aquatic life. Experience gained through conducting stream-quality reconnaissances will assist with the design and evaluation of data-collection programs to meet cost-effective goals.

\section{REGIONAL SEDIMENT CHARACTERISTICS}

\section{By EdMUnd D. ANDREwS}

The sediment load of streams is a primary factor determining the quality of water and its suitability for various uses. Sediment load also significantly affects the hydraulic stability of a stream channel, as well as the aquatic habitat. The supply of sediment to the channel network, and, thus, to the sediment load of the stream, is the result of many factors. Of these factors, land use is probably the factor most readily affected by human activity. Extensive changes in land use are anticipated in the Yampa River basin during the next 15 years, due primarily to energy-resources and associated economic development. A regional sediment appraisal of the Yampa River basin was conducted to evaluate areal differences in sediment loads in streams and to assess possible changes in sediment loads due to projected increases in surface mining of coal (Andrews, 1978).

Using available historical data for 17 gaging stations in the Yampa River basin, the mean annual sediment load was computed using the streamflowduration, sediment-rating-curve method described by Miller (1951). A functional relation between the total sediment load and water discharge was determined by summing the suspended-load and bedload relations (Andrews, 1978). Then, the mean annual total sediment load at a gaging station was computed by combining the total sediment-load relation with the average annual frequency of various discharges recorded at the station. The mean annual suspended, bedload, and total sediment loads as well as mean annual discharge at the 17 gaging stations in the Yampa River basin were summarized by Andrews (1978, table 2).

A comparison of the values at the individual stations in the basin indicated that the source areas of sediment and streamflow are quite different (Andrews, 1978). The Little Snake River subbasin, with an area of $3,730 \mathrm{mi}^{2}\left(9,660 \mathrm{~km}^{2}\right)$ upstream from Lily, Colo., supplies 27 percent of the annual runoff to the Yampa River at Deerlodge Park and 69 percent of the sediment load. Conversely, the Yampa River subbasin, with an area of $3,410 \mathrm{mi}^{2}$ $\left(8,830 \mathrm{~km}^{2}\right)$ upstream from near Maybell, Colo., contributes 73 percent of the runoff and only 27 percent of the estimated total sediment load for the entire Yampa River basin.

A sediment-yield map of the Yampa River basin (fig. 11) was prepared, using computed average unit-area sediment yields at each gaging station. Two areas with sediment yields ranging from 300 to 500 tons $/ \mathrm{mi}^{2}$ (105 to $175 \mathrm{t} / \mathrm{km}^{2}$ ) per year occurred in the basin (fig. 11). The area drained by the Little Snake River contributes approximately 60 percent of the total sediment load of the Yampa River at Deerlodge Park. The area, drained primarily by Milk Creek and the Williams Fork-both tributaries to the Yampa River, contributes approximately 20 percent of the annual sediment load of the Yampa River at Deerlodge Park.

About 48 percent of the Yampa River basin has sediment yields ranging from 110 to 300 tons $/ \mathrm{mi}^{2}$ (35 to $105 \mathrm{t} / \mathrm{km}^{2}$ ) per year (fig. 11). The smallest sediment yields-less than 100 tons $/ \mathrm{mi}^{2}\left(35 \mathrm{t} / \mathrm{km}^{2}\right)$ 


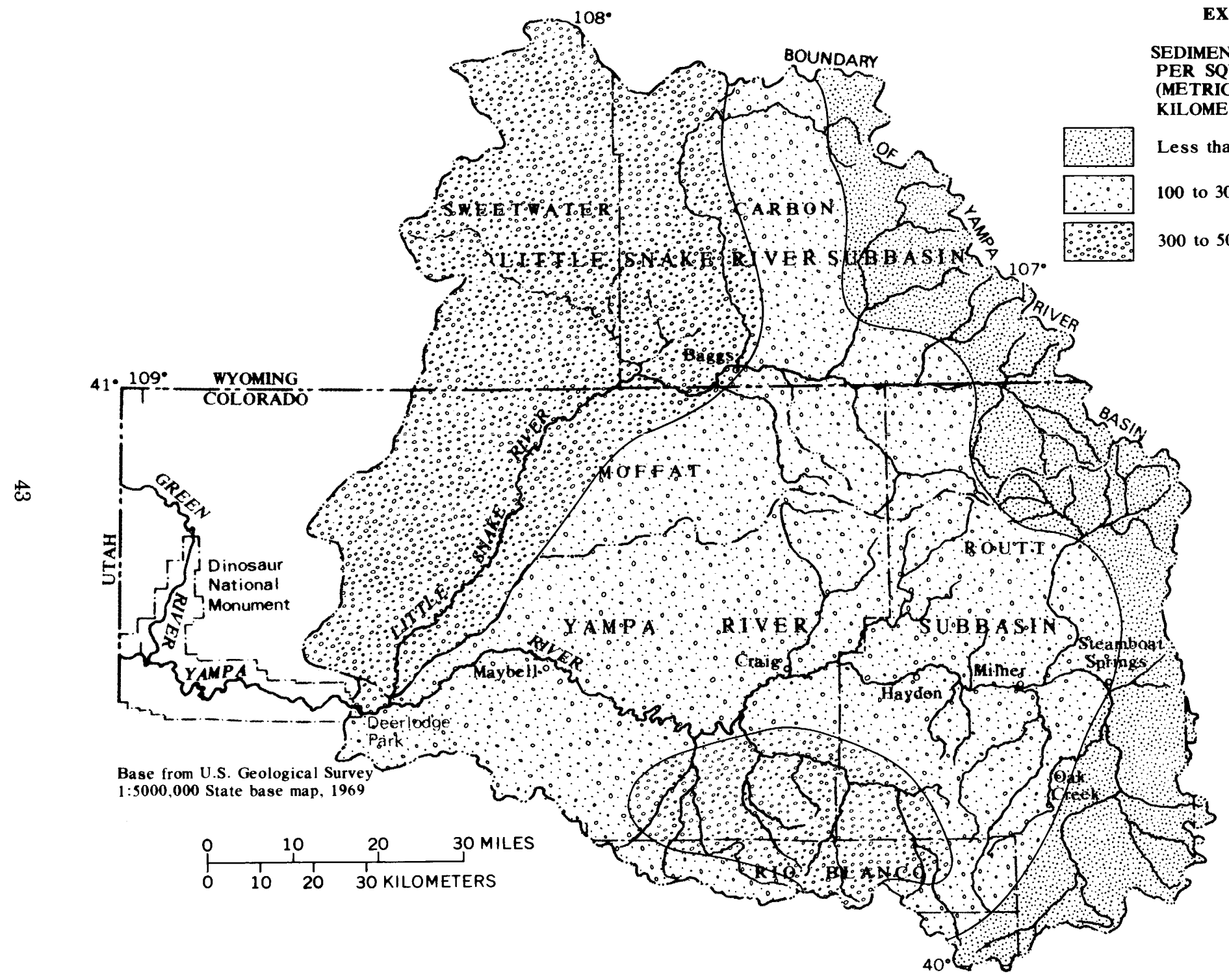

EXPLANATION

SEDIMENT YIELDS, IN TONS

PER SOUARE MILE PER YEAR METRIC TONS PER SQUARE TER PER YEAR)

100 (Less than 30)

300 (30 to 91 )

to 500 (91 to 152$)$ 
per year-occur along the eastern margin of the basin. This area is approximately $1,300 \mathrm{mi}^{2}(3,370$ $\mathrm{km}^{2}$ ) or 17 percent of the basin.

As a result of coal-resource development, land disturbances in mine areas and in urban centers will probably increase the quantity of sediment supplied to stream channels. The Surface Mining Control and Reclamation Act of 1977 (Public Law 95-87) requires that sediment-detention ponds be constructed and that surface-mined areas be reclaimed and revegetated according to specified standards. During and immediately following mining, however, the hillslopes will have greater runoff and erosion rates than the original undisturbed hillslopes. As reclamation proceeds and vegetation becomes reestablished, the erosion rates should gradually decrease to rates comparable to adjacent undisturbed hillslopes (I. C. James II, E. D. Attanasi, T. Maddock III, S. H. Chiang, B. T. Bower, and N. C. Matalas, written commun., 1978).

Increases in sediment loads of streams due to surface mining were estimated using a method developed by the Pacific Southwest Inter-Agency Committee (1968). This method rates the effects of surface mining using nine characteristics of a watershed: surface geology, soil profile, climate, runoff, topography, ground cover, land use, upland erosion, and channel erosion. Estimated sediment yield is determined by comparing the numerical score of the watershed being evaluated with the numerical score of watersheds with measured sediment yields. This method is appropriate for estimating the increased sediment yield due to surface mining, because certain categories, such as soil and vegetation cover, will change, whereas other categories, such as surface geology and climate, should not change appreciably.

The three alternative levels of coal production through 1990 described previously (table 1) were assumed for this analysis (Udis and others, 1977; Steele and others, 1979). Based on these projections and other assumptions described by Andrews (1978), the areas of land being mined as well as partly reclaimed can be calculated annually for each of the three levels of production through 1990 .

The estimated quantities of sediment that would be eroded from surface-mined areas through 1990 are summarized in table 9. An estimated additional 10,000 to 30,000 tons $(9,000$ to $27,000 t)$ of sediment will be supplied to the mainstem Yampa
River annually during $1985-90$ due to surface mining within the basin (table 9). These estimates compare favorably with the estimates of 4,500 to 30,000 tons $(4,000$ to $27,000 \mathrm{t})$ per year made by the U.S. Department of the Interior (1976a), and also compare favorably with the 10,000 to 44,000 tons $(9,000$ to $40,000 \mathrm{t})$ per year estimated for the basin by 1990 using values of total gross output and multiplying them by residuals coefficients for suspended solids (Steele, 1978a; adapted from table 5 in this report). These latter estimates are slightly larger because indirect impacts are incorporated into the residuals coefficients.

The impacts of this additional sediment load in the Yampa River and its tributaries will depend in part on where within the basin surface mining takes place. Surface mining in the eastern part of the basin, where sediment yields are generally less than 100 tons $/ \mathrm{mi}^{2}\left(35 \mathrm{t} / \mathrm{km}^{2}\right)$ per year (fig. 11), may substantially increase the quantity of sediment supplied to the stream channels. For example, if all new surface mines in the basin were located in areas upstream of the gaging station on the Yampa River near Hayden (fig. 2), the estimated increase in sediment load at this location would be 10 to 30 percent, and would be the result of mining only about 1 to 3 percent of the contributing drainage area.

It is doubtful, however, that all additional mining will be located upstream of the gaging station near Hayden (U.S. Department of the Interior, 1976a). A more realistic estimate is that only about 50 percent of the new surface mines will be located upstream of Hayden. Thus, the probable increase in the sediment load of the Yampa River near Hayden due to surface mining through 1990 will be 5 to 15 percent, depending upon the volume of coal production.

Farther west in the basin, the relative impact of increased sediment yields due to the surface mining will be less for two reasons. First, existing sediment yields are already relatively large due to sparse ground cover and a lack of soil development. Thus, surface mining will not greatly alter these factors and, hence, the relative increase in sediment yield will be small. Second, areas of surface mining in the western part of the basin actually being disturbed are relatively small. Hence, the additional sediment load of the Yampa River at the gaging station near Maybell due to surface mining will be an estimated 2 to 7 percent of the present 


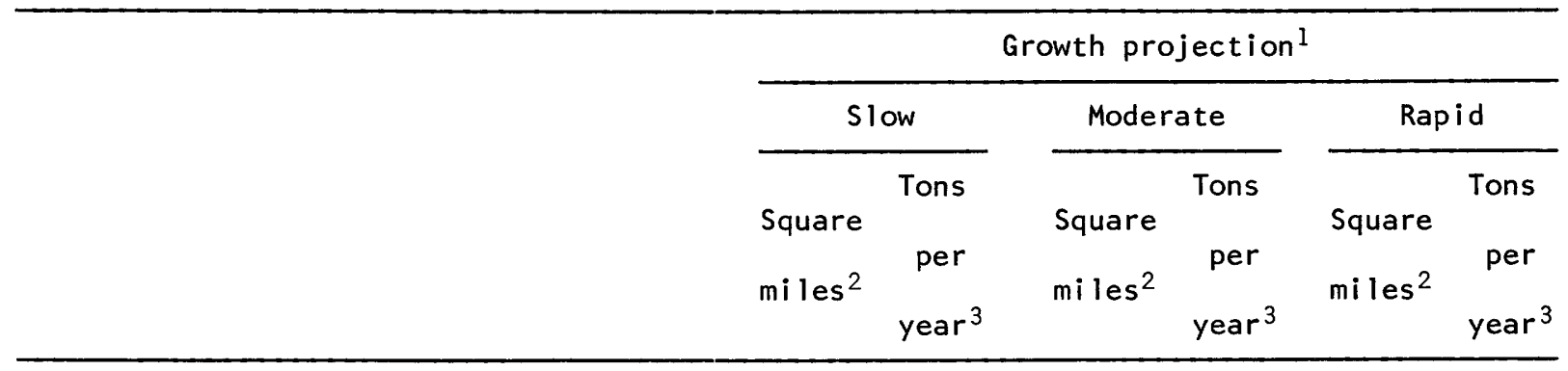

1975-80:

$\begin{array}{llll}\text { Area mined-1 } & 2.0 & 2.9 & 3.4 \\ \text { Area partly reclaimed-1-- } & 0 & 0 & 0\end{array}$

Total sediment yield from surface-

mined and partly reclaimed areas------- $4,500 \quad 6,700 \quad 7,800$ 1980-85:

$\begin{array}{llll}\text { Area mined-1 } & 2.6 & 4.9 & 7.3 \\ \text { Area partly reclaimed-1- } & 2.0 & 2.9 & 3.4\end{array}$

Total sediment yield from surface-

mined and partly reclaimed areas------- $\quad 8,100 \quad 15,000 \quad 21,000$ 1985-90:
Area mined-1-
3.1
6.0
9.4
Area partly reclaimed--
2.6
4.9
7.3

Total sediment yield from surface-

mined and partly reclaimed areas----- 10,000

19,000

30,000

I Projected coal production from Steele, Bauer, Wentz, and Warner (1979, table 4).

${ }^{2}$ Assuming 50 acres of land are mined to produce $1 \mathrm{million}$ tons of coal.

${ }^{3}$ Sediment yields have been adjusted to reflect a basin of 40 square miles.

mean annual sediment load at that site, depending upon the volume of coal production (Andrews, 1978).

In conclusion, even at the greatest projected volume of coal production in the basin by 1990 , the additional quantity of sediment contributed to the streams will be small when compared to the total quantity of sediment currently being transported out of the Yampa River subbasin or the basin in its entirety. Additional studies, such as that outlined by Smith (1980), will be needed to assess the effects of potential changes of sediment regime on fish and aquatic life in streams of the Yampa River basin. Moreover, the impacts of sediment entrapment by 
proposed reservoirs in the Yampa River system or any other region impacted by surface mining or associated economic development will need to be considered in any basinwide analysis.

\section{REMOTE-SENSING APPLICATIONS}

\section{By FREDERICK J. HeIMES}

Effective planning for optimal allocation of natural resources requires the collection and analysis of large amounts of diverse data on a timely basis. The potential for using remotesensing applications to provide various types of information on a timely basis was investigated using Landsat (Land-satellite) data and small-scale color and color-infrared aerial photographs (Heimes and other, 1978). Landsat data were used for: (1) regional land-use classification and mapping, (2) lineament mapping, and (3) mapping of areal snow cover. Aerial photographs were used for estimating turbidity in selected streams.

Traditional methods of inventorying and updating land-use information are costly and timeconsuming, especially in large areas like the Yampa River basin, where land use is diverse and changing rapidly. Landsat provides repetitive imagery of large areas that may be suitable for defining and updating land-use categories on a regional scale. Using the land-use classification system suggested by Anderson, Hardy, Roach, and Witmer (1976) as a guide, a Landsat classification of selected areas in the Yampa River basin was made (Heimes and others, 1978). Certain limitations in classifying sparsely vegetated areas and irrigated hay meadows were identified.

Demands and competition for surface-water resources are increasing in the Yampa River basin. Consequently, expanded development of groundwater resources may occur. Landsat imagery provides the areal coverage necessary to detect major lineaments, which may indicate faults or fracture zones with potential for increased groundwater availability (Goetz and others, 1975; Moore and Deutsch, 1975).

For demonstration purposes, interpreted lineaments were superimposed on a Landsat scene, with mapped faults obtained from geologic maps (fig. 12). Only a small percentage of the mapped faults corresponded to the interpreted lineaments. The lack of correlation is not necessarily significant, because lineaments can be a manifestation of fractures and faults indicated only by subtle topo- graphic and vegetative trends that are not readily discernible during ground mapping. Limitations of this technique are described by Heimes, Moore, and Steele (1978). Wells being drilled in the region should provide additional information for verification of the inferred correlations between groundwater occurrence and faults or fractures.

A large percentage of the total annual streamflow in the Yampa River basin is contributed by snowmelt runoff (Steele and others, 1979). Landsat data can provide the information necessary to map areal snow extent in large watersheds (Barnes and Bowley, 1974). This areal assessment, combined with an estimation of water equivalent of snow, could be a useful tool for forecasting basinwide surface-water availability (Leaf, 1971; Brown and Hannaford, 1975).

In areal classification of snow cover, clouds commonly have spectral characteristics similar to snow. This causes problems in delineating snow extent on Landsat scenes containing clouds. Snow areas also may be obscured by dense conifer forests (Rango, 1975, p. 61, 231). This was not a major problem in classifying snow-covered areas in the western part of the basin because few dense conifer forests occur in this part of the basin. However, in mountainous areas of the eastern part of the basin, which supply the majority of the snowmelt runoff, dense conifer stands created some problems in classification (Heimes and others, 1978).

Expansion of surface coal mining probably will increase sediment loads in the basin's streams. Construction of buildings and roads and increased dryland farming also may increase sediment loads. Large sediment loads may be indicated by increased turbidity in streams. Aerial photography, used in conjunction with a few ground-control data points, may be a rapid method for assessing turbidities in streams (Ritchie and others, 1976). Changes in turbidity in a water body result in changes in reflected energy which may be recorded on photographs. The sensitivity of color and colorinfrared photographs to changes in turbidity was evaluated to determine if turbidity could be indirectly (quantitatively) measured using the photographs.

Results of an investigation in which turbidity measurements were made concurrently with aerial photographs for part of the basin indicated a correlation of $R^{2} \geq 0.90$ between reflectance values and measured turbidity values (Heimes and others, 1978). This correlation of spectral reflectance with 


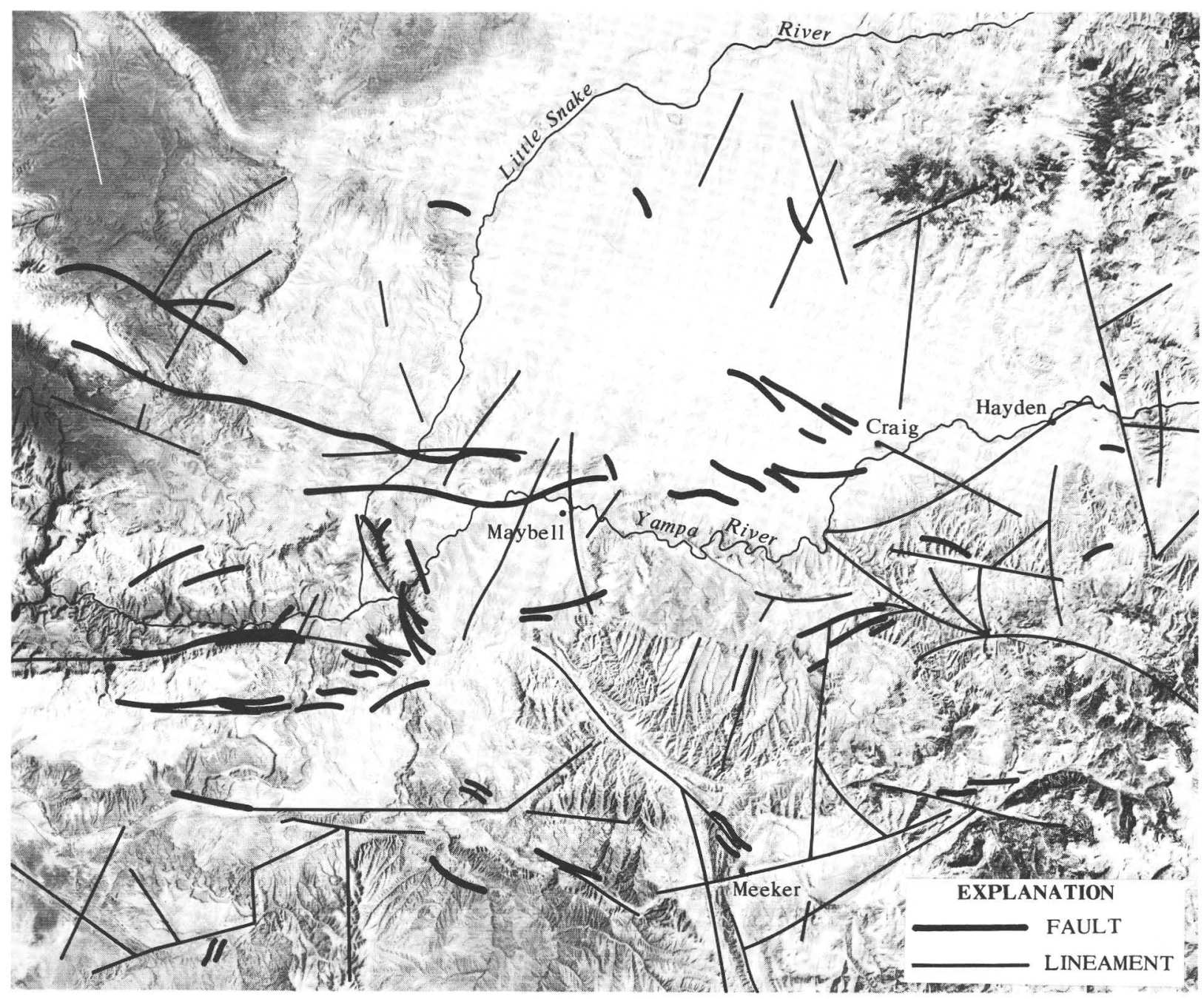

F IGURE 12.-Lineament and fault map superimposed on Landsat scene that includes the western part of the Yampa River basin, February 26, 1975. (From Heimes and others, 1978.)

turbidity measurements indicated that there may be potential for using aerial photography to infer turbidity of streams, with minimal ground-data collection required.

In conclusion, results from the remote-sensing investigations indicated that satellite data and aerial photographs may be useful, in many instances, in conjunction with traditional techniques for timely regional assessment of the variables discussed. The investigations conducted were designed as a preliminary evaluation of the feasibility of using remote-sensing applications and were not oriented toward the development of operational procedures. However, results from these studies could lead to operational techniques using remote-sensing technology. Such techniques would facilitate the rapid collection and analysis of some data required for efficient allocation of resources on a regional basis.

\section{SOLUTE-TRANSPORT MODELING OF GROUND WATER}

\section{BY JAMES W. WARNER}

Projected water demands for coal-resource and associated economic development, coupled with limited supplies of surface water and proposals to export surface water out of the basin, have resulted in renewed interest to selectively develop groundwater supplies. Coal resources in the Yampa River basin are being and will be mined primarily by 
surface-stripping techniques from the Mesaverde Group of Late Cretaceous age, a thick sequence of interbedded sandstones, shales, and coal (U.S. Department of the Interior, 1976a). The Mesaverde Group also is one of the major aquifer systems in the basin (Brogden and Giles, 1977). Most of the planned coal mines in the basin will be in the Williams Fork Mountains, a major recharge area for the Mesaverde Group. Adverse changes in groundwater quality may result if uncontrolled infiltration of water occurs through mine waste-spoil piles and pits containing fly and bottom ash from powerplants (table 5).

Two digital-computer models were constructed for the Mesaverde Group aquifer system in the Twentymile Park and the Williams Fork Mountains areas (fig. 2) to evaluate the effects of this potential ground-water degradation. The models assumed nonreactive mass transport of conservative substances and were based on mathematical-solution techniques described by Pinder and Bredehoeft (1968), Reddel and Sunada (1970), and by Bredehoeft and Pinder (1973).

The models were calibrated by comparing measured ground-water levels with model-calculated ground-water levels. In addition, measurements of ground-water discharge at springs and gain-loss measurements of ground-water discharge along selected stream reaches draining the model areas were compared with model-calculated quantities of ground-water flow. Model construction, data used, and details concerning the calibration of the two study models are discussed in detail by J. W. Warner and R. H. Dale (written commun., 1980).

Model simulations of assumed projected conditions were used to calculate the potential effects of regional coal-resource development on the quality of the ground-water system. The capability of the models to realistically predict water-quality conditions depends on the accuracy of the calibration and the degree to which model assumptions and input data are representative of future conditions. Very little disruption of the sandstone aquifers is expected as the result of the coal mining; thus, the direction and rate of ground-water movement should not be substantially altered. Furthermore, it was assumed that mining operations would not affect the long-term average recharge to the aquifer. Disruption of the earthen material overlying the coal was assumed to neither increase nor decrease the long-term infiltration rate of precipitation. The ground water in the model areas was assumed to be in a continuous state of equilibrium with regard to recharge, discharge, and characteristics of the aquifer (J. W. Warner and R. H. Dale, written commun., 1980).

A critical problem of water-quality degradation by coal mining involves dissolution of materials by water percolating through disturbed overburden materials. Results of a recent study by McWhorter, Skogerboe, and Skogerboe (1975) in the eastern part of the Yampa River basin indicated a general increase in all major chemical constituents in water that came in contact with the waste-spoil piles at coal mines-either as runoff or as percolation; dissolved solids in leachate from the waste-spoil piles increased from 2,200 to $7,300 \mathrm{mg} / \mathrm{L}$. In the model simulations reported by J. W. Warner and R. H. Dale (written commun., 1980), an assumed increase of $5,000 \mathrm{mg} / \mathrm{L}$ in dissolved-solids concentrations in the leachate draining from mined areas into the ground water was used.

To demonstrate the application of this modeling technique, the effects of uncontrolled point-source contamination on ground-water quality were simulated for five existing surface-coal mines in the Twentymile Park model area. The effects on the ground-water quality from all mines in the Twentymile Park model area after 20 years is shown on figure 13a. Degraded ground water would occur in much of the southern and eastern parts of the model area and would occupy an area of about 57 $\mathrm{mi}^{2}\left(148 \mathrm{~km}^{2}\right)$. An increase in dissolved-solids concentration of $200 \mathrm{mg} / \mathrm{L}$ in the ground water would be typical within a 0.5 - to $1.0-\mathrm{mi}(0.3-$ to $1.6-\mathrm{km})$ radius of the mines. Degraded ground-water discharge would occur to all streams in the model area and would result in incremental increases in dissolved-solids concentration in several of the streams at low flows (J. W. Warner and R. H. Dale, written commun., 1980).

After 60 years, degraded ground water would occupy an area of about $76 \mathrm{mi}^{2}\left(197 \mathrm{~km}^{2}\right)$ and would extend throughout much of the model area (fig. $13 B$ ). The incremental increases in dissolved-solids concentration at low flows in several streams would become correspondingly greater. The dissolved solids discharged annually to these streams as the result of coal mining would be about 100,000 tons $(90,000 \mathrm{t})$, which would be about 50 percent of the increase in dissolved solids resulting from mining in the ground-water system. The remainder (about 90,000 tons or $81,000 \mathrm{t}$ ) would remain in the aquifer. 


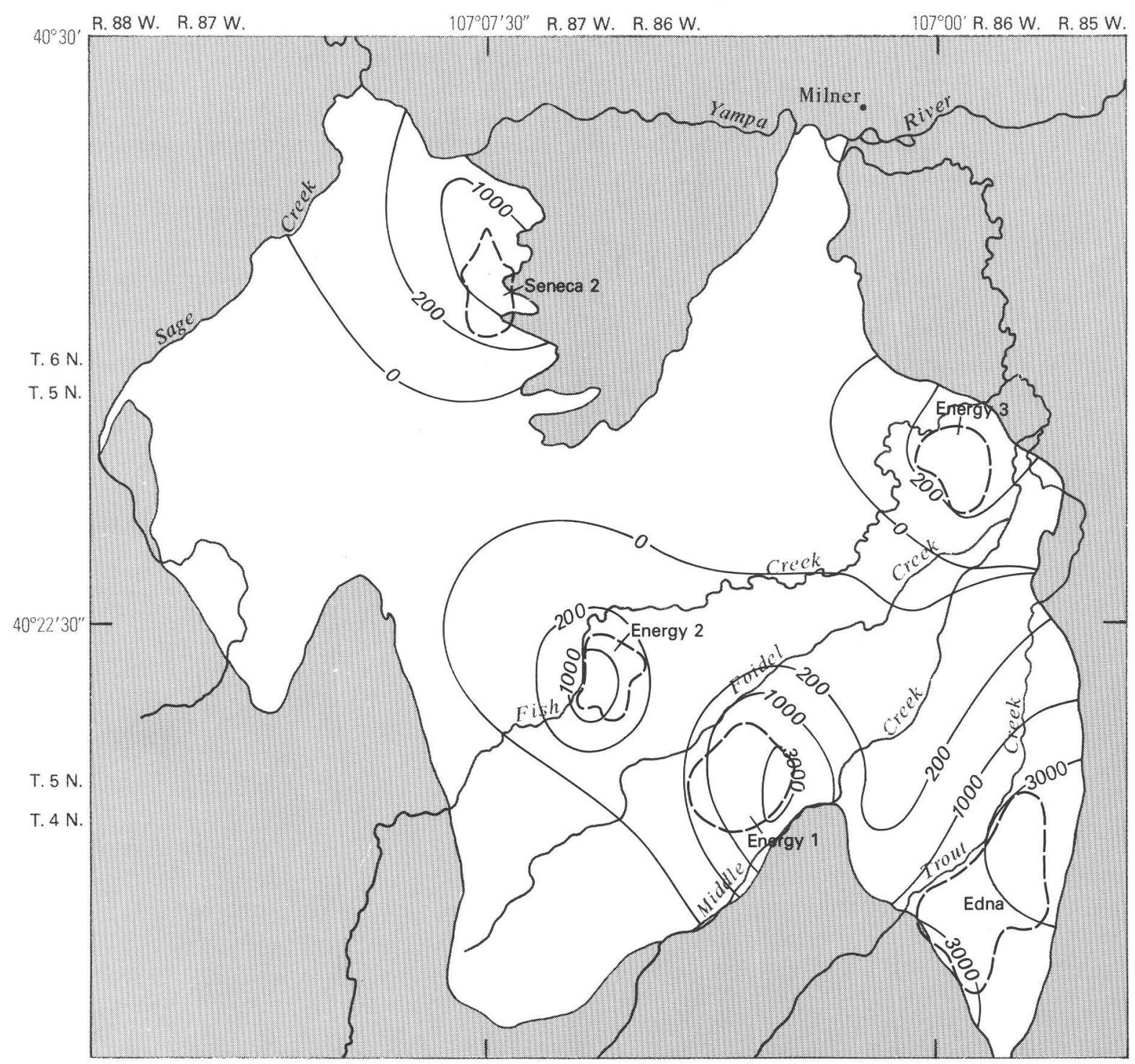

A. After 20 years

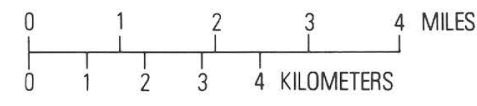

EXPLANATION
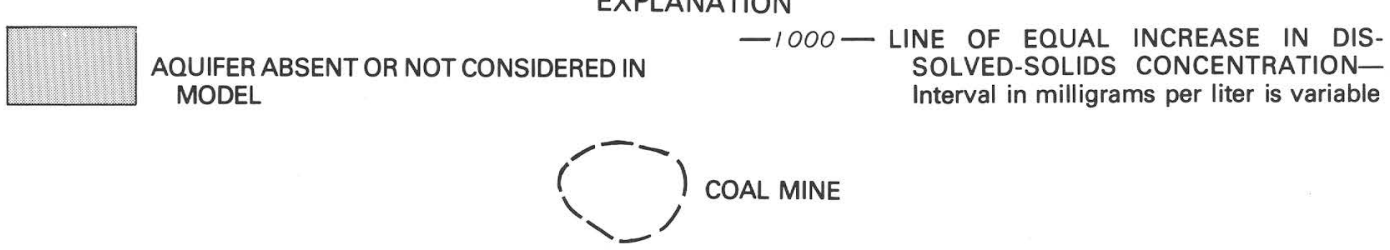

FIGURE 13.-Projected increases in dissolved-solids concentrations in ground water resulting from all mines in the Twentymile Park model area. (From J.W. Warner and R. H. Dale, written commun., 1980.) (A) after 20 years; (B), after 60 years; and (C), after 200 years.

After 200 years, degraded ground water would occupy most of the model area (fig. 13C). Degraded ground water with an increase in dissolved-solids concentrations of greater than $200 \mathrm{mg} / \mathrm{L}$ would ex- 


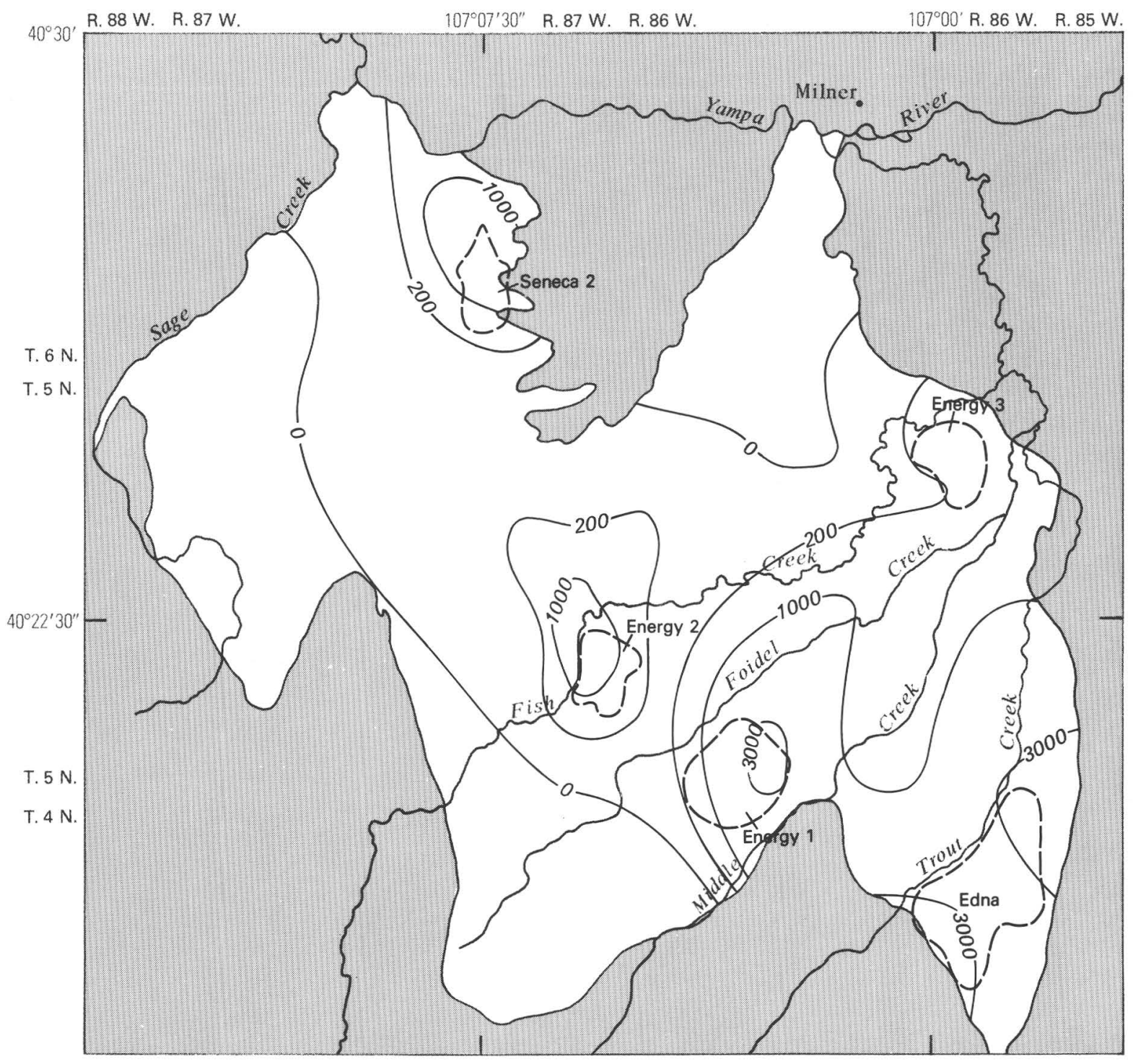

B. After 60 years

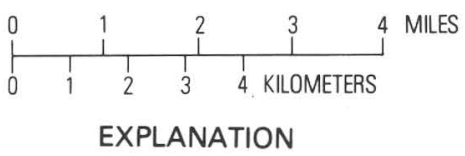

- 1000 - LINE OF EQUAL INCREASE IN DIS SOLVED-SOLIDS CONCENTRATIONInterval in milligrams per liter is variable

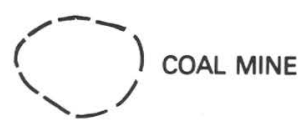

F IGURE 13.-Continued 


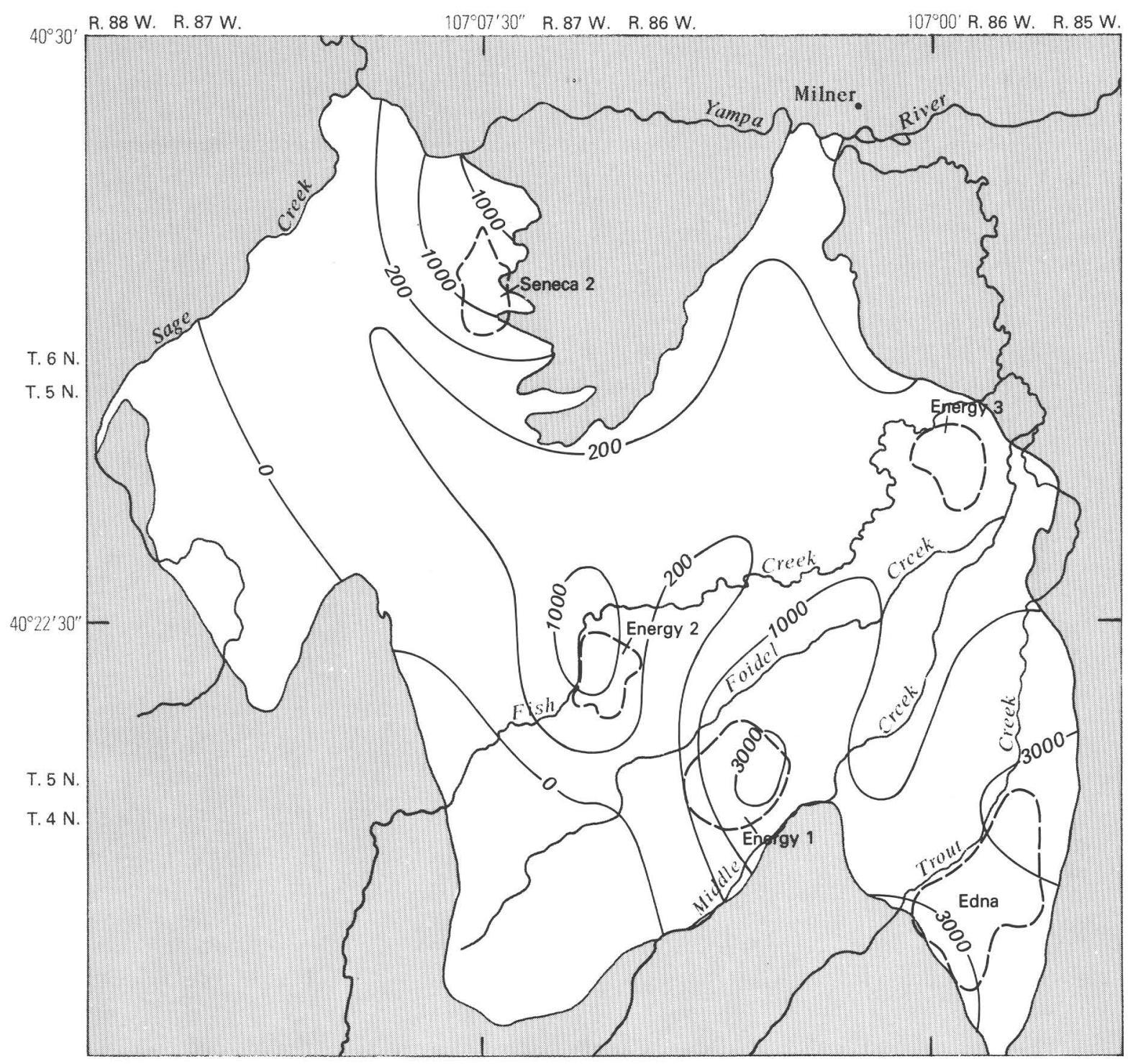

C. After 200 years
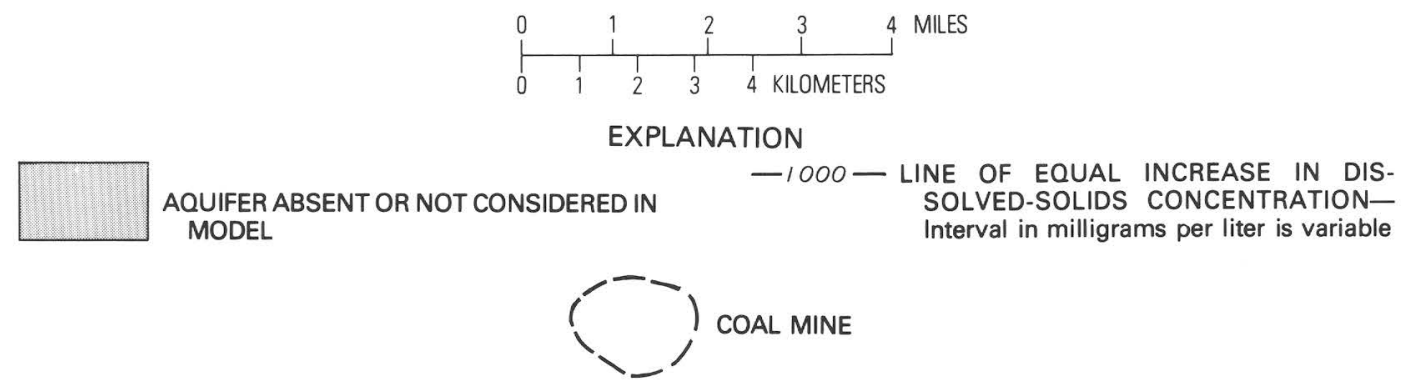

F IGURE 13.-Continued. 
tend almost to the Yampa River and would occupy an area of about $52 \mathrm{mi}^{2}\left(135 \mathrm{~km}^{2}\right)$. The spread of degraded ground water would be relatively slow-primarily because most degraded ground water would discharge into one of the streams draining the model area. The quality of water in the Yampa River should not be markedly degraded by the increase in dissolved-solids concentrations in these tributaries or by direct discharge of degraded ground water. The relatively greater base flows in the Yampa River contributed by upstream tributaries should mask most of the effects of the mine-degraded ground waters reaching the stream, assuming that future upstream water demands and use do not significantly decrease the base flows.

Detailed results of other model simulations for the Twentymile Park and Williams Fork Mountains model areas are given by J. W. Warner and R. H. Dale (written commun., 1980). As both mining and ground-water development increase, additional modeling will be useful in assessing potential changes in ground-water quality.

This form of modeling analysis may be used throughout the country to predict possible changes in the quality of water in aquifers affected by coal mining. By using predictive modeling, the time changes in ground-water quality and the magnitude of the changes may be estimated. Also, delineating potential problem areas would aid in determining the location of wells needed to monitor actual changes in ground-water quality.

\section{SUMMARY}

In the Yampa River basin assessment, a variety of water-resources-related studies was conducted, using, whenever possible, data from several alternative projections of economic growth, estimates of discharged residuals and water use associated with this growth, and numerous types of field data. It is important to note that, ideally, the economicprojection analysis and the residuals and water-use estimates should precede the water-resourcesrelated studies to aid in defining the scope and level of detail for such studies. This preferential sequence of ordering of study components was not always followed in conducting the Yampa River basin assessment. In order to meet project deadlines, several physical-based studies were conducted prior to or concurrently with the regional economic analyses. Hence, assumptions initially made during water-resources-related studies may well have been refined or modified, based upon information obtained subsequently in other studies.

The basin assessment attempted to link economic growth with residuals and water-use estimates. One should be cognizant of the inherent uncertainties, both in growth projections and in the coefficients, to estimate residuals and water use and of other limitations in this procedure. A range of possible options is available which may affect discharged residuals and water use. Factors included in these options include costs of treatment to comply with effluent discharge or ambient stream standards, institutional as well as physical constraints on residuals-disposal alternatives, ranges of water-use influences by water availability (both in a legal and physical sense), and treatment of hydrologically related residuals to achieve acceptable water quality.

Emphasis of the Yampa River basin-assessment water-resources studies, for the most part, was to demonstrate methods rather than to provide results from which specific inferences or recommendations could be made. The overall study framework was to apply techniques which could evaluate the anticipated effects of regional economic growth. These techniques are, in essence, screening tools, which indicate the types and forms of detailed physical-based analyses and data that might provide useful information to assist designated authorities in resource planning and management. Moreover, the interactive nature of these analyses has been demonstrated and needs to be kept in mind as the need arises for reevaluation of future conditions.

Legal and institutional constraints exist that may affect the availability and quality of water resources required for energy-related development in the Yampa River basin. The doctrine of prior appropriation and the two interstate compacts affecting the waters of the basin-the Colorado River Compact of 1922 and the Upper Colorado River Basin Compact of 1948-are among these constraints. More recent legislation involving water quality needs to be evaluated interactively with these prior regulations allocating amounts of surface water.

The dominant seasonal use of diverted surface waters for irrigation of hay meadows and grain crops may be offset in part by increasing yearround uses of water for industries and muncipalities. Analysis and evaluation of waterwithdrawal records may indicate certain instances 
where economic incentives might be proposed to promote more efficient water use.

Assuming that the water desired for direct uses in coal-resource development can be obtained, the series of physical-based studies outlined in this summary report indicate several water-related consequences of such development which need to be considered. First, additional year-round uses of water for industries and municipalities probably will occur. This promotes a strong interest in impoundment of flows during high-runoff periods to distribute the seasonal pattern of streamflow more evenly throughout the year. Competition for surface waters may induce greater development of the basin's ground-water resources. Increased amounts and additional types of residuals may impact upon the environment.

Some of the highlighted studies were designed to evaluate the assimilative capacity and possible rate of disposal of residuals created as a result of coal-resource and related economic development. Due to implementation of upstream surface-water storage structures and possible transbasin diversions, in-stream flows may well be altered in terms of seasonal patterns, annual amounts, and associated quality characteristics. Additional interactive studies need to be implemented to intermittently reevaluate such changes, particularly in lieu of recently passed or proposed regulations affecting the extent of such changes.

\section{REFERENCES}

Adams, D. B., 1975, Predicted and observed temperatures and water-quality changes of lakes and reservoirs in International Association of Scientific Hydrology Symposium, Tokyo, Japan, December 1975, Proceedings: International Association of Scientific Hydrology Publication 117, p. 873-882.

Anderson, J. R., Hardy, E. E., Roach, J. J., and Witmer, R. E., 1976, A land use and land cover classification system for use with remote-sensor data: U.S. Geological Survey Professional Paper 964, 28 p.

Andrews, E. D., 1978, Present and potential sediment yields in the Yampa River basin, Colorado and Wyoming: U.S. Geological Survey Water-Resources Investigations 78-105, 33 p.; available from U.S. Department of Commerce, National Technical Information Service, Springfield, VA 22161, as report PB-292 677.

Barnes, J. C., and Bowley, C. J., 1974, Handbook of techniques for satellite snow mapping: Environmental Research and Technology, Inc., no. 407-A, 93 p.

Bauer, D. P., Rathbun, R. E., and Lowham, H. W., 1979, Traveltime, unit-concentration, longitudinal-dispersion, and reaeration characteristics of upstream reaches of the
Yampa and Little Snake Rivers, Colorado and Wyoming: U.S. Geological Survey Water-Resources Investigations 78-122, 66 p.; available from U.S. Department of Commerce, National Technical Information Service, Springfield, VA 22161, as report PB-80 129521.

Bauer, D. P., Steele, T. D., and Anderson, R. D., 1978, Analysis of waste-load assimilative capacity of the Yampa River, Steamboat Springs to Hayden, Routt County, Colorado: U.S. Geological Survey Water-Resources Investigations 77-119, 69 p.; available from U.S. Department of Commerce, National Technical Information Service, Springfield, VA 22161, as report PB-278 051.

Beckner, J. L., 1976, Geohydrological data requirements for environmental impact statements, in Methodologies for Environmental Assessment in Energy Developing Regions Symposium, San Francisco, Calif., December [abs.]: Transactions, American Geophysical Union, v. 57, no. 12, p. 916.

Bennett, J. P., and Rathbun, R. E., 1972, Reaeration in openchannel flow: U.S. Geological Survey Professional Paper 737, $75 \mathrm{p}$.

Boning, C. W., 1974, Generalization of stream travel rates and dispersion characteristics from time-of-travel measurements: U.S. Geological Survey Journal of Research, v. 2, no. 4, p. 495-499.

Bower, B. T., and Basta, D. J., 1973, Residuals-environmental quality management-Applying the concept: Baltimore, Md., Center for Metropolitan Planning and Research, $88 \mathrm{p}$.

Bredehoeft, J. D., and Pinder, G. F., 1973, Mass transport in flowing ground water: Water Resources Research, v. 9, no. 1, p. 194-210.

Britton, L. J., 1979, Reconnaissance evaluation of surface-water quality in Eagle, Grand, Jackson, Pitkin, Routt, and Summit Counties, Colorado: U.S. Geological Survey Open-File Report 79-420, 285 p.

Brogden, R. E., and Giles, T. F., 1977, Reconnaissance of ground-water resources in a part of the Yampa River basin between Craig and Steamboat Springs, Moffat and Routt Counties, Colorado: U.S. Geological Survey WaterResources Investigations 77-4, scale 1:250,000, 1 sheet.

Brown, A. J., and Hannaford, J. F., 1975, Interpretation of snowcover from satellite imagery for use in water supply forecasts in the Sierra Nevada, in Operational applications of satellite snowcover observations: Washington, D.C., National Aeronautics and Space Administration Special Paper 391, p. 39-51.

Colorado Department of Health, 1977, Proposed water quality standards for Colorado (draft no. 9; November 17, 1977): Denver, $51 \mathrm{p}$.

Colorado Department of Natural Resources, 1980, Upper Colorado River Basin 13 (a) assessment-The availability of water for oil shale and coal gasification development in the Upper Colorado River Basin: Summary Report to the U.S. Water Resources Council, 9 chaps.

Colorado Revised Statutes, 1973, State of Colorado, amendments.

Gathers and Associates, Inc., 1976, Comprehensive plan for Routt County, Colorado: Steamboat Springs, Routt County Planning Department, $500 \mathrm{p}$.

Giles, T. F., and Brogden, R. E., 1978, Selected hydrologic data, Yampa River basin, and parts of the White River basin, northwestern Colorado and south-central Wyoming: U.S. Geological Survey Open-File Report 78-23, 91 p. 
Goetz, A. F. H., Billingsley, F. C., Gillespie, A. R., Abrams, M. J., Squires, R. L., Shoemaker, E. M., Lacchitta, I., and Elston, D. P., 1975, Application of ERTS images and image processing required in geologic probing and geologic mapping in northern Arizona: Pasadena, Calif., Jet Propulsion Laboratory, Technical Report 31-1597, 118 p.

Gold, H., Goldstein, D. J., Probstein, R. F., Shen, J. S., and Yung, D., 1977, Water requirements for steam-electric power generation and synthetic fuel plants in the western United States: U.S. Environmental Protection Agency, Contract No. 68-01-1916, EPA Rept. No. 600/7-77-037, April, 259 p.

Gray, S. L., and McKean, J. R., 1975, An economic analysis of water use in Colorado's economy: Fort Collins, Colorado State University, Environmental Research Center, Completion Report Series 10, 113 p.

Greeson, P. E., Velz, C. J., and Rickert, D. A., 1977, Riverquality assessment: American Water Resources Association, Water Resources Bulletin, v. 13, no. 3, June, p. 445-453.

Haefele, E. T., 1971, A utility theory of representative government: American Economic Review, v. 61, June, p. 350-367.

Heimes, F. J., Moore, G. K., and Steele, T. D., 1978, Preliminary applications of Landsat images and aerial photography for determining land-use, geologic, and hydrologic characteristics-Yampa River basin, Colorado and Wyoming: U.S. Geological Survey Water-Resources Investigations 78-96, $48 \mathrm{p}$.

Hirsch, R. M., 1979, Spatial variation in annual water consumption rates for three cooling technologies: Poster Paper, American Water Resources Association, 15th Annual Meeting, Las Vegas, Nev., September 24-26, 1979.

Hirsch, R. M., James, I. C., II, and Schefter, J. E., 1978, Residuals management-A tool in river quality assessment applied to coal development in the Yampa River basin, Colorado, in P. E. Greeson, ed., River Quality Assessments Special Symposium, 13th Annual Meeting, Tucson, Ariz., November 2-3, 1977, Proceedings: Minneapolis, Minn., American Water Resources Association, p. 142-164.

Holland, W. E., 1975, Mixing oil and water-The effect of prevailing water law doctrines on oil-shale developments: Denver Law Journal, v. 52, Art. 657.

Howe, C. W., Kreider, J. F., Udis, Bernard, Hess, R. C., Orr, D. V., and Young, J. T., 1975, Integrated economichydrosalinity-air quality for oil shale and coal development in Colorado, in Future Energy Alternatives for Colorado Symposium, Boulder, Colorado University, Economics Department, December 1975, Proceedings: Colorado Energy Research Institute, January 1976, v. II, appendix C, 85 p.

Iorns, W. V., Hembree, C. H., and Oakland, G. L., 1965, Water resources of the Upper Colorado River Basin-Technical report: U.S. Geological Survey Professional Paper 441, 370 p.

Iorns, W. V., Hembree, C. H., Phoenix, D. A., and Oakland, G. C., 1964, Water resources of the Upper Colorado River Basin-Basic Data: U.S. Geological Survey Professional Paper 442, 1036 p.

Jacoby, G.C., Weatherford, G. C., and Wegner, J. W., 1976, Law, hydrology, and surface-water supply in the Upper Colorado River Basin: American Water Resources Association, Water Resources Bulletin, v. 12, no. 5, October, p. 973-984.

James, I. C., II, and Steele, T. D., 1977, Application of residuals-management techniques for assessing the impacts of alternative coal-development plans on regional water resources: Third International Symposium in Hydrology,
Fort Collins, Colorado State University, June 27-29, 1977, Proceedings, p. 682-702, 23 p. reprint.

Keefer, W. F., and Hadley, R. F., 1976, Land and natural resource information and some potential environmental effects of surface mining of coal in the Gillette area, Wyoming: U.S. Geological Survey Circular 743, 27 p.

Kneese, A. V., and Bower, B. T., 1968, Managing water quality-Economics, technology, institutions: Baltimore, The Johns Hopkins Press, published for Resources for the Future, Inc., 328 p.

Knudsen, W. I., Jr., and Danielson, J. A., 1977, A discussion of legal and institutional constraints on energy-related water development in the Yampa River basin, northwestern Colorado: Completion Report for U.S. Geological Survey Contract No. 14-08-001-15075, December, 20 p.

Leaf, C. F., 1971, Areal snow cover and disposition of snowmelt runoff in central Colorado: Fort Collins, Colo., U.S. Department of Agricultural, Forest Service, Research Paper RM-66, 19 p.

Lowham, H. W., 1978, An analysis of stream temperatures, Green River basin, Wyoming: U.S. Geological Survey WaterResources Investigations 78-13, 41 p.; available from U.S. Department of Commerce, National Technical Information Service, Springfield, VA 22161, as report PB-284 062.

Luken, R. A., 1974, Economic and social impacts of coal development in the 1970's for Mercer County, North Dakota: Washington, D.C., Old West Regional Commission, 206 p.

Maddock, Thomas, III, and Matalas, N. C., 1980, Impact of energy development of water resources in the Yampa River basin: in W. O. Spofford, Jr., A. L. Parker, and A. V. Kneese, eds., Energy development in the Southwest; Problems of Waters, Fish, and Wildlife in the Upper Colorado River Basin, Albuquerque, N. Mex., October 15-16, 1976, Proceedings: Washington, D.C., Resources for the Future, v. 2, p. 331-354.

McQuivey, R. S., and Keefer, T. N., 1976, Convective model of longitudinal dispersion: American Society of Civil Engineers, Journal of the Hydraulics Division, v. 102, no. HY-10, p. 1409-1424.

McWhorter, D. B., Skogerboe, R. K., and Skogerboe, S. V., 1975, Water quality control in mine spoils, Upper Colorado River Basin: U.S. Environmental Protection Agency, Technical Series, Report EPA-670/2-75-048, June, 99 p.

Miernyk, W. H., 1965, The elements of input-output analysis: New York, Random House, 156 p.

Miller, C. R., 1951, Analysis of flow duration sediment rating curve method of computing sediment yield: Washington, D.C., U.S. Bureau of Reclamation, $55 \mathrm{p}$.

Moore, G. K., and Deutsch, Morris, 1975, ERTS imagery for ground water investigations: Ground Water, v. 13, no. 12, p. 214-226.

National Academy of Engineering, 1972, Engineering for resolution of the energy-environment dilemma: Washington, D.C., $340 \mathrm{p}$.

National Academy of Sciences, 1968, Water and choice in the Colorado River basin-An example of alternatives in water management: Washington, D.C., Committee on Water of the National Research Council, Publication 1689, 107 p.

Norton, Underwood, and Lamb, Engineering Associates, 1978, Craig area facilities plan for wastewater treatment works: Greeley, Colo., Prepared for city of Craig, Colo., Project No. 76040, August, 95 p., plus appendices. 
Oak Creek Power Company, 1976, Oak Creek water and power project, Colorado: Denver, Colo., Van Sickle Associates, Inc., Consulting Engineers, 22 p.

Pacific Southwest Inter-Agency Committee, 1968, Report on factors affecting sediment yield in the Pacific Southwest area: Water Management Subcommittee, Sedimentation Task Force, 10 p., 2 tables.

Palmer, R. N., James, I. C., II, and Hirsch, R. M., 1977 (1978), Comparative assessment of water use and environmental implications of coal slurry pipelines: U.S. Geological Survey Open-File Report 77-298, 29 p., published also in Hydrological Sciences Bulletin, v. 23, no. 4, December 1978, p. 455-469.

Pinder, S. F., and Bredehoeft, J. D., 1968, Application of the digital computer for aquifer evaluation: Water Resources Research, v. 4, no. 5, p. 1069-1093.

Rango, Albert, ed., 1975, Operational applications of satellite snowcover observations: Washington, D.C., National Aeronautics and Space Administration Special Paper 391, $430 \mathrm{p}$.

Reddell, D. L., and Sunada, D. K., 1970, Numerical simulation of dispersion in ground-water aquifers: Fort Collins, Colorado State University, Hydrology Paper 41, 79 p.

Reynolds, J. Z., 1980, Power plant cooling systems - Policy alternatives: Science, v. 207, no. 4429, 25 January 1980, p. 367-372.

Ribbens, R. W., 1975, Program NW01, river network program, users manual: Denver, Colo., U.S. Bureau of Reclamation, Engineering and Research Center, Division of Planning and Coordination, 7 chaps. and appendices.

Ritchie, J. C., Schiebe, E. R., and McHenry, J. R., 1976, Remote sensing of suspended sediments in surface waters: Photogrammetric Engineering and Remote Sensing, v. 42, no. 12 , p. $1539-1545$.

Rölvaag, O. E., 1927, Giants in the earth: New York, Harper and Row, $173 \mathrm{p}$.

Sanders, T. G., Ward, R. C., Loftis, J. C., Steele, T. D., Adrian, D. D., and Yevjevich, V. J., 1980, Principles of network design for water quality monitoring: Fort Collins, Colorado State University, July, 311 p.

Smith, R. A., 1980, Predicting the effects of surface coal mine erosion on trout populations in the Yampa River basin, in W. O. Spofford, Jr., A. L. Parker, and A. V. Kneese, eds., Energy development in the Southwest; Problems of Waters, Fish, and Wildlife in the Upper Colorado River Basin, Albuquerque, N. Mex., October 15-16, 1976, Proceedings: Washington, D.C., Resources for the Future, v. 2, p. 395-437.

Steele, T. D., 1976, Coal-resource development alternatives, residuals management, and impacts on the water resources of the Yampa River basin, Colorado and Wyoming, in Water Resources and Fossil Fuel Production Symposium, Düsseldorf, Germany, September 7-8, 1976, Proceedings: International Water Resources Association, Article 28, $17 \mathrm{p}$.

1978a, Assessment techniques for modeling water quality in a river basin affected by coal-resource development, in Modelling the Water Quality of the Hydrological Cycle International Symposium, Baden, Austria, September 11-15, 1978, Proceedings (16-page reprint): International Association of Scientific Hydrology, Publication no. 125, p. $322-332$.

1978b (1979), An overview of river-basin assessment methodologies in an energy-impacted region-Yampa River basin, Colorado and Wyoming, in P. E. Greeson, ed., River Quality Assessments Special Symposium, 13th Annual Meeting, Tucson, Ariz., November 2-3, 1977, Proceedings: Minneapolis, Minn., American Water Resources Association, p. 43-64; published also in Water Supply and Management, v. 3, no. 4, September 1979, p. 151-171.

1980, The potential impacts of energy development on water resources in the Yampa River basin-A discussion, in W. O. Spofford, Jr., A. L. Parker, and A. V. Kneese, eds., Energy development in the Southwest; Problems of Waters, Fish, and Wildlife in the Upper Colorado River Basin, Albuquerque, N. Mex., October 15-16, 1976, Proceedings: Washington, D.C., Resources for the Future, v. 2, p. 373-394.

Steele, T. D., Bauer, D. P., Wentz, D. A., and Warner, J. W., 1976a, An environmental assessment of impacts of coal development on the water resources of the Yampa River basin, Colorado and Wyoming-Phase-I work plan: U.S. Geological Survey Open-File Report 76-367, 17 p.

1979, The Yampa River basin, Colorado and Wyoming-A preview to expanded coal-resource development and its impacts on regional water resources: U.S. Geological Survey Water-Resources Investigations 78-126, 133 p.; available from U.S. Department of Commerce, National Technical Information Service, Springfield, VA 22161, as report PB-300 815.

Steele, T. D., James, I. C., II, Bauer, D. P., and others, 1976b, An environmental assessment of impacts of coal development on the water resources of the Yampa River basin, Colorado and Wyoming-Phase-II work plan: U.S. Geological Survey Open-File Report 76-368, 33 p.

Tsivoglou, E. C., and Neal, L. A., 1976, Tracer measurement of reaeration, Part III. Predicting the reaeration capacity of inland streams: Journal of the Water Pollution Control Federation, v. 48 , no. 12 , p. $2669-2689$.

Udis, Bernard, Adams, T. R., Hess, R. C., and Orr, D. V., 1977, Coal energy development in Moffat and Routt Counties of the Yampa River basin in Colorado-Projected primary and secondary economic impacts resulting from several coaldevelopment futures: Completion Report for U.S. Geological Survey Contract P.O. 12185, June, 342 p.

Udis, Bernard, and Hess, R. C., 1976, Input-output structure of the economy of Routt and Moffat Counties of the Yampa River basin in Colorado - 1975: Completion Report for U.S. Geological Survey Contract P.O. 12166, December, 146 p.

U.S. Army Corps of Engineers, 1968, HEC-3, Reservoir systems analysis: Hydrologic Engineering Center Users Manual No. 238-53, 86 p.

U.S. Bureau of Reclamation, 1974, Alternative sources of water for prototype oil-shale development, Colorado and Utah: Salt Lake City, Utah, Upper Colorado Region, 114 p.

U.S. Department of the Interior, 1976a, Northwest Colorado Coal-Environmental Statement: U.S. Bureau of Reclamation, December 1976, Regional Analysis plus five sitespecific analyses, 4 vols.

1976b, Savery-Pothook Project, Colorado and Wyoming-Draft Environmental Statement: U.S. Bureau of Reclamation, Upper Colorado Region, Salt Lake City, Utah, INT DES 76-37, September 27, 1976, 9 chap. plus attachments.

U.S. Environmental Protection Agency, 1977, Steamboat Springs Regional Service Authority, 201 Wastewater facilities plan-Final environmental impact statement: Denver Colo., 
Region VIII, prepared by Weiner \& Assoc., Report EPA-908/5-77-005, August, 243 p.

U.S. Geological Survey, 1976, Hydrologic studies of the U.S. Geological Survey related to coal development in Colorado: U.S. Geological Survey Open-File Report 76-549, 22 p.

1978, Water resources data for Colorado-Water year 1977: U.S. Geological Survey Water-Data Report CO-77-3, $412 \mathrm{p}$.

Upper Colorado River Commission, [1965-77], Selected legal references: Salt Lake City, Utah, 3 vols. and index.

Van Zandt, Thomas, 1975, Water for oil shale-Some institutional alternatives for water allocation in arid rural regions: American Water Resources Association, Water Resources Bulletin, v. 11, no. 6, December, p. 1181-1186.

Weatherford, G. D., and Jacoby, G. C., 1975, Impact of energy development on the law of the Colorado River: National Resources Journal, v. 15, no. 1, p. 171-213.

Wentz, D. A., 1974, Stream quality in relation to mine drainage in Colorado: American Water Resources Association Proceedings 18, p. 158-173.

Wentz, D. A., and Steele, T. D., 1978, Surface-water quality in the Yampa River basin, Colorado and Wyoming - An area of accelerated coal development, in G. M. Karadi and R. J. Kirzek, eds.: Water for Energy Development, Engineering Foundation, Asilomar Conference Grounds, Pacific Grove, Calif., December 5-10, 1976, Proceedings, p. 56-74.

1980, An analysis of stream quality in the Yampa River basin, Colorado and Wyoming: U.S. Geological Survey Water-Resources Investigations 80-8, 157 p., available from U.S. Department of Commerce, National Technical Information Service, Springfield, VA 22161, as report PB-81 108904.

Willingham, T. W., 1976, Ammonia toxicity: Denver, Colo., U.S. Environmental Protection Agency, Region VIII, Central Technology Branch, Report EPA 908/3-76-001, 96 p.

Woodward-Clyde Consultants, 1977, Supplemental report to the U.S. Environmental Protection Agency on Lake Catamount Dam and Reservoir: Report for Pleasant Valley Investment Co., May 11, 1977.

Wyoming State Engineer's Office, 1970, Water and related land resources of the Green River basin, Wyoming: Wyoming Water Planning Program, Report no. 3, September, 137 p. 

